RO̊̊M

Royal Ontario Museum
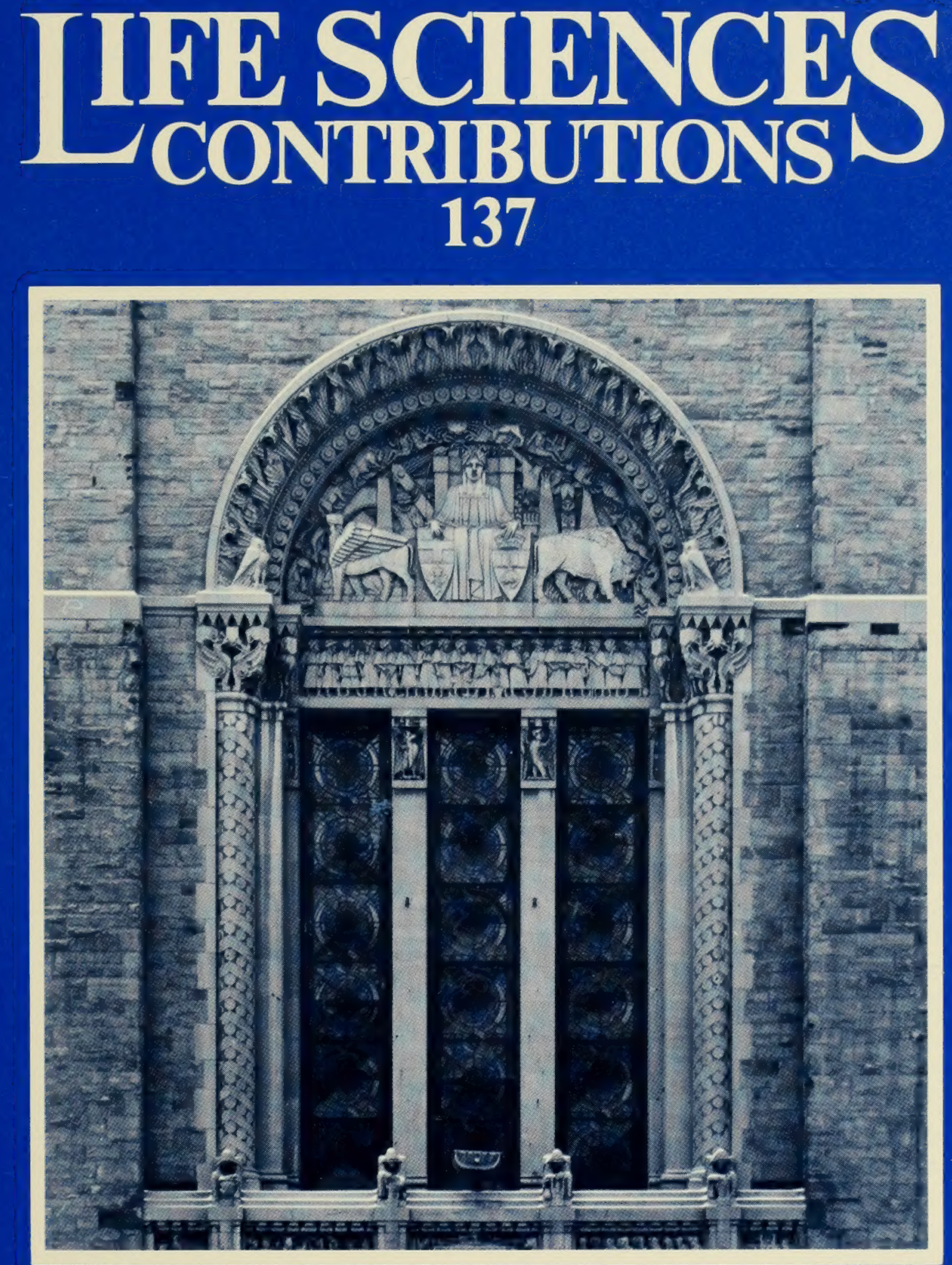

Early Llandovery Crinoids and Stelleroids from the Cataract Group (Lower Silurian) in Southern Ontario, Canada

James D. Eckert 


\section{ROYAL ONTARIO MUSEUM LIFE SCIENCES PUBLICATIONS INSTRUCTIONS TO AUTHORS}

Authors should prepare their manuscripts carefully according to the following instructions; failure to do so will result in the manuscript's being returned to the author for revision. All manuscripts are considered on the understanding that they are not currently offered for publication elsewhere.

1. General Papers for publication are accepted from ROM staff members and research associates, and from researchers reporting on work done with ROM collections. Monographs on the flora and/or fauna of Ontario may be considered for publication by authors not affiliated with the ROM. Financial contributions towards publication will be welcome. Authors are expected to write clearly and concisely and to omit any material not essential for an understanding of the main theme of the paper.

2. Format Manuscripts (including captions, synonymies, literature cited, and tables) should be typed with double space on 11 " $\times 8 \frac{1}{2}$ " paper with a $1 \frac{1}{2}$ " margin on all sides. Three xerox copies should be submitted to the Senior Editor of the Editorial Board; the original should be retained by the author(s). The submission should include a separate sheet giving the author(s) names and affiliations, the title of the publication, the series for which it is submitted, the number of typed pages, the number of tables, and the number of plates or figures. Manuscripts should normally be organized in the following order: Contents, Abstract, Introduction, Materials and Methods, Results, Discussion, Conclusions, Summary (if manuscript is long), Acknowledgements, Appendices, and Literature Cited. Authors are encouraged to include foreign-language translations of the Summary, if appropriate. Main headings should be centred; subheadings should be left-justified to the text margin. The first line of the first paragraph in each new section should not be indented. Literature citations in the text should be in the form "Jones (1972)" or "(Jones, 1972)" or "'(Smith, 1960:71-79, fig. 17)".

3. Standard Sources The primary authority on questions of format and style is Guide to Authors, available from ROM Publication Services. For matters not covered in the Guide, consult CBE (AIBS) Style Manual (3rd Edition). Other standard sources are as follows: for English spelling, The Concise Oxford Dictionary; for Canadian place names and coordinates, Canada Gazetteer Atlas; for the spelling of geographic names, The Times Atlas.

4. Abstract All papers must be preceded by a short, factual abstract, about one per cent of the text in length. The abstract may be followed by four to six key words in parentheses.

5. Taxonomy The name of a taxon should be given in full in headings, at the beginnings of paragraphs, and at its first occurrence in the text. Give the authority and date, if appropriate, with the first mention of each taxon, but not thereafter. Taxonomic papers, particularly synonymies, should follow the layout in Life Sciences Contributions beginning with No. 136. International Codes of Biological Nomenclature must be followed.

6. Literature Cited A complete list of references, in alphabetical order of authors, must be given at the end of the paper. When two or more works of one author are cited, they should be listed chronologically. The names of journals should not be abbreviated. For correct bibliographic form, see Life Sciences Contributions beginning with No. 136 .

7. Tables All tables should be typed on separate sheets and numbered consecutively in arabic numerals in the order of their first mention in the text. Mark the location of each table in the margin of the text.

8. Plates, Figures, and Text-figures Illustrations may be designated according to the conventions of the author's discipline; in some disciplines grouped photographs of scientific subject matter are commonly termed Plates, while line drawings and locality and other illustrations that occupy a full page or less are Text-figures. Usage must be consistent throughout the paper. A full-page illustration for a Contribution, with its caption, should be sized to fit an area of $17.3 \times$ $22.75 \mathrm{~cm}$; for Occasional Papers, the area is $14.1 \times$ $21.2 \mathrm{~cm}$. If captions are lengthy, they may be placed on the facing page. A scale or magnification factor should be included. Authors are reminded that when illustrations are reduced magnification factors will change, and that they are responsible for the conversion. For details, see Guide to Authors. 


\title{
Early Llandovery Crinoids and Stelleroids from the Cataract Group (Lower Silurian) in Southern Ontario, Canada
}

\author{
James D. Eckert
}

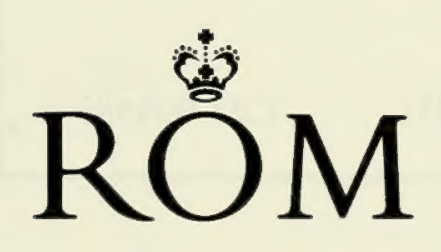

THE ROYAL ONTARIO MUSEUM 


\section{ROYAL ONTARIO MUSEUM PUBLICATIONS IN LIFE SCIENCES}

The Royal Ontario Museum publishes three series in the Life Sciences:

Contributions: a numbered series of original scientific publications.

Occasional Papers: a numbered series of original scientific publications, primarily short and of taxonomic significance.

Miscellaneous Publications: an unnumbered series on a variety of subjects.

All manuscripts considered for publication are subject to the scrutiny and editorial policies of the Life Sciences Editorial Board, and to independent refereeing by two or more persons, other than Museum staff, who are authorities in the particular field involved.

LIFE SCIENCES EDITORIAL BOARD

Senior editor: R. Winterbottom

Editor: J. R. Tamsitt

Editor: D. R. Calder

Manuscript editor: R. Winterbottom

James D. Eckert completed his M.Sc. studies in the Department of Geology at the University of Toronto and is currently pursuing doctoral studies in the Department of Geological Sciences at the University of Rochester, New York 14627.

\section{Canadian Cataloguing in Publication Data}

Eckert, James D., 1952-

Early Llandovery Crinoids and Stelleroids from the Cataract Group (Lower Silurian) in Southern

Ontario, Canada

(Life sciences contributions, ISSN 0384-8159; no. 137)

Bibliography: p.

ISBN 0-88854-298-4

1. Crinoidea, Fossil. 2. Starfishes, Fossil.

3. Paleontology - Silurian. 4. Paleontology - Ontario

- Niagara Peninsula. I. Royal Ontario Museum.

II. Title. III. Series.

QE782.E33 563'.91'0971351 C83-098585-9

Publication date: 31 January 1984

ISBN 0-88854-298-4

ISSN 0384-8159

(C) The Royal Ontario Museum, 1984

100 Queen's Park, Toronto, Canada, M5S 2C6

PRINTED AND BOUND IN CANADA AT THE ALGER PRESS 


\section{Contents}

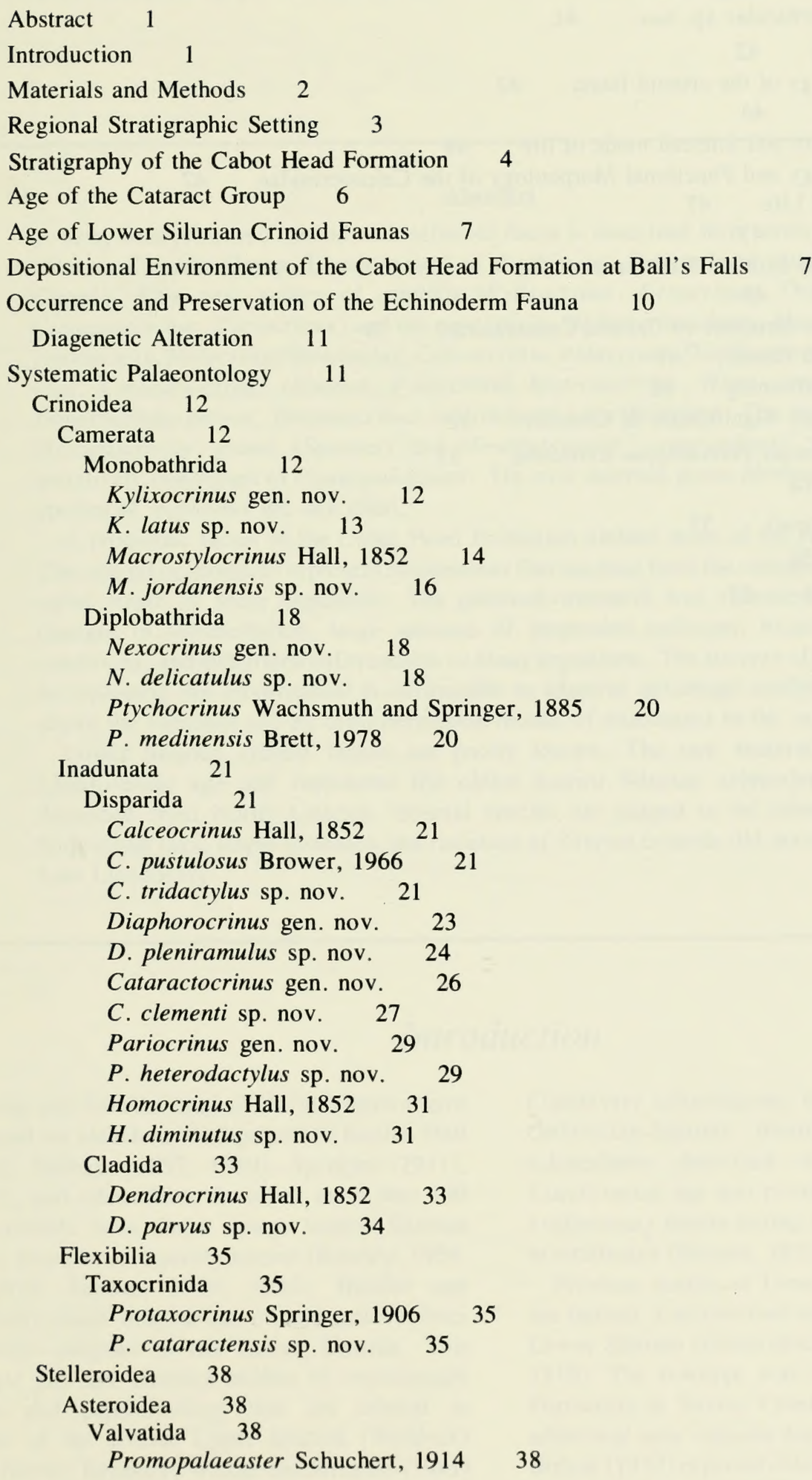


P.? granti (Spencer) 1884, n. comb. 38

Medinaster gen. nov. 41

M. orbiculus sp. nov. 41

Palaeoecology 42

Palaeoecology of the crinoid fauna 42

Autecology 44

Attachment and inferred mode of life $\quad 44$

Palaeoecology and Functional Morphology of the Calceocrinidae

Modes of Life

47

Holdfasts $\quad 47$

Crown and Column Structures 48

Synecology 49

Population Structure of Crinoid Communities

Associated Fauna 49

Niche Partitioning 51

Palaeoecologic Significance of Crinoids $\quad 52$

Ordovician-Silurian Pelmatozoan Evolution 53

Summary $\quad 54$

Acknowledgements 55

Appendix 56

Literature Cited 57

Plates $\quad 63$ 


\title{
Early Llandovery Crinoids and Stelleroids from the Cataract Group (Lower Silurian) in Southern Ontario, Canada
}

\begin{abstract}
A new, well-preserved crinoid and stelleroid fauna is described from strata of the Lower Silurian Cataract Group (Llandoverian) in the Niagara Peninsula in southern Ontario, Canada. Five new genera of crinoids (Kylixocrinus, Nexocrinus, Diaphorocrinus, Cataractocrinus, Pariocrinus) and ten new species (Kylixocrinus latus, Macrostylocrinus jordanensis, Nexocrinus delicatulus, Calceocrinus tridactylus, Diaphorocrinus pleniramulus, Cataractocrinus clementi, Pariocrinus heterodactylus, Homocrinus diminutus, Dendrocrinus parvus, Protaxocrinus cataractensis) are described. The asteroid species Mesopalaeaster granti (Spencer) and Mesopalaeaster? cataractensis Schuchert are tentatively reassigned to Promopalaeaster. The new asteroid genus Medinaster and new species $M$. orbiculus are described.

A prodeltaic facies of the Cabot Head Formation yielded most of the study material. The crinoid occurrences represent biocoenoses that resulted from the catastrophic burial of entire stands of these organisms. The palaeoenvironment was characterized by rapid changes in sedimentation, large amounts of suspended sediment, localized reducing conditions, and substrates unfavourable to many organisms. The success of pelmatozoans in exploiting this environment is attributable to adaptive advantage conferred by height above the substrate and by semi-permanent modes of attachment to the sea floor.

Lower Silurian crinoid faunas are poorly known. The new material is of Early Llandoverian age and represents the oldest known Silurian echinoderm fauna yet described from North America. Several species are judged to be closely related to Ordovician taxa. Rapid evolution and radiation of Silurian crinoids did not occur until the Late Llandovery.
\end{abstract}

\section{Introduction}

The Ordovician and Silurian strata of North America have long been noted for abundant, well-preserved fossils. Hall (1847, 1852), Billings (1857, 1859), Springer (1911), Ulrich (1925), and others have described more than 140 genera of crinoids from these strata. Lower Silurian echinoderms, however, are poorly known (Rowley, 1904; Springer, 1919; Foerste, 1919, 1936). Bassler and Moodey (1943) listed only seven crinoid genera from strata currently assigned to the Lower Silurian. This palaeontologic gap has inhibited studies of evolutionary relationships and palaeoecology that are critical to investigations of the diverse Upper Silurian (Wenlock) echinoderm faunas. Recently, Witzke and Strimple (1981) have added substantially to our knowledge of Late
Llandovery echinoderms, but information on the critical Ordovician-Silurian transition remains limited. The echinoderms described in this report are of Early Llandoverian age and provide a clearer understanding of evolutionary trends during a time of crisis among marine invertebrates (Boucot, 1975; Sheehan, 1975).

Previous studies of Lower Silurian crinoids of Ontario are limited. Calceocrinus ontario (Springer) was the first Lower Silurian crinoid described from Ontario (Springer, 1919). The holotype was collected from the Manitoulin Formation at Stoney Creek. Johnson (1934) discovered additional new crinoids but his work was not published. Bolton (1957) reported Alisocrinus? carleyi from strata he assigned to the Power Glen Formation at DeCew Falls on 


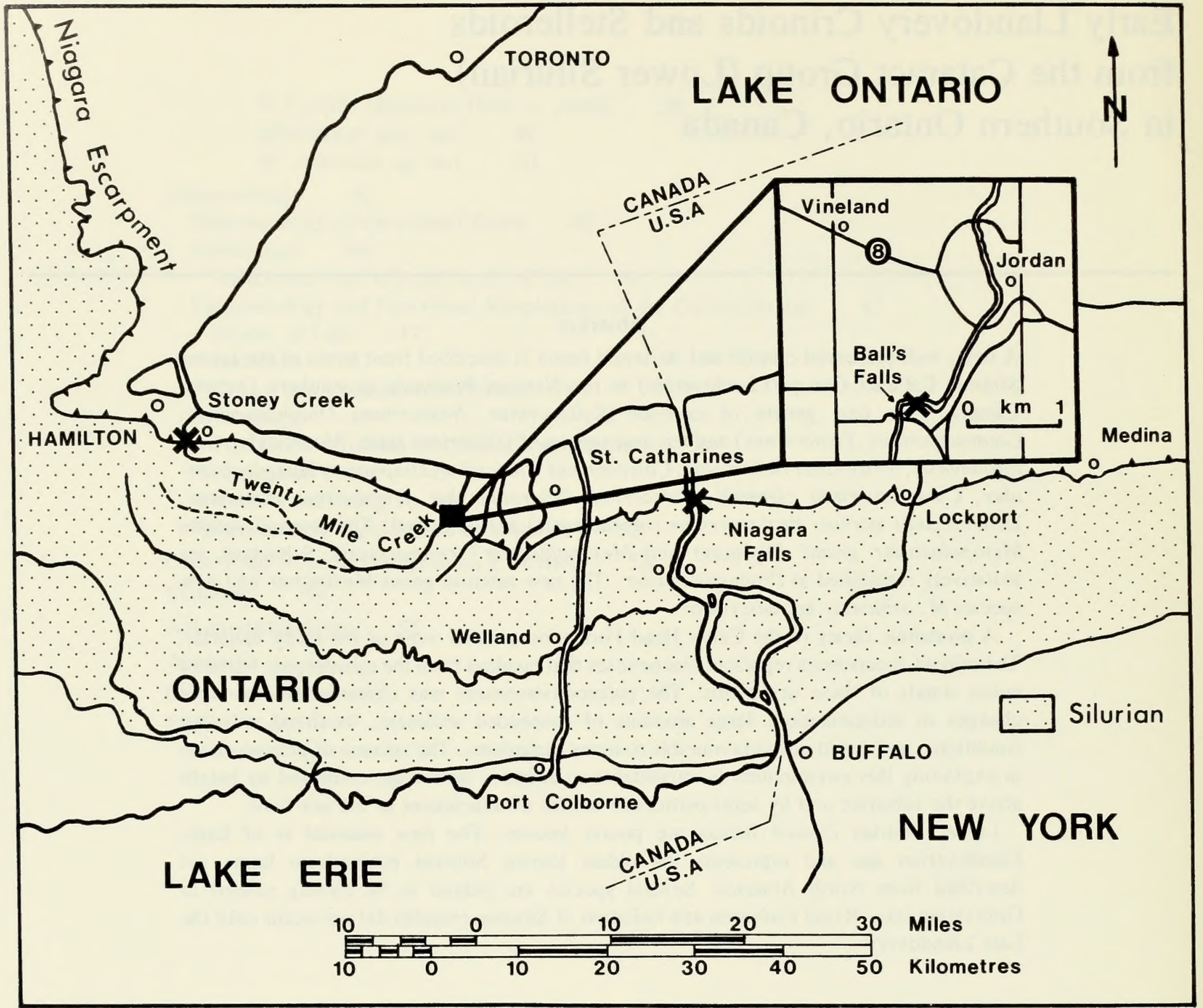

Text-fig. 1 Locality map of southwestern Ontario and western New York State showing occurrences $(\mathbf{x})$ of echinoderms in the Cataract Group.

Twelve Mile Creek. Brower (1966) described Calceocrinus pustulosus from the Manitoulin Formation at Stoney Creek. Brett (1978a) described Ptychocrinus medinensis from the lower Medina Group in the Niagara Gorge near Lewiston in New York State.

\section{Materials and Methods}

A complete section of the Cabot Head Formation is exposed in the gorge below the lower falls at Ball's Falls on Twenty Mile Creek, near Jordan, Ontario, $25 \mathrm{~km}$ west of Niagara Falls (Text-fig. 1). Most of the material that forms the basis of this report was collected from this locality during May 1977 and April 1978. Collecting was most productive at those times since the stream had scoured and cleared the outcrop of talus and other debris, rendering visible crinoid ossicles that would otherwise have been overlooked.

Most specimens were recovered through excavation of favourable areas. The precise horizon of each occurrence was determined using a hand-held level. The scrubbing of slabs in the field with a toothbrush revealed many 
echinoderms that would otherwise have been overlooked. In the laboratory, the material was prepared with the use of a Microblaster airbrasive machine with dolomite powder.

Immersion in ethanol facilitated study of certain specimens. Plate diagrams were traced over photographs. Most specimens were blackened and then coated with ammonium chloride sublimate before being photographed. A readily removable black pigment was devised by the dilution of Grumbacher black acrylic paint with ethanol. The resulting solution dries rapidly, producing a matt surface. After photography, the scrubbing of the specimen with a toothbrush soaked in ethanol readily removed the pigment. The writer recommends the use of this product in preference to India ink and other pigments that permanently blacken specimens. A water-based product was not used since water tended to make the matrix crumble.

\section{Regional Stratigraphic Setting}

Southern Ontario is underlain by essentially undeformed Cambrian to Upper Devonian strata that dip southerly away from the Precambrian Shield at 5.5 to $8.5 \mathrm{~m}$ per $\mathrm{km}$ (20 to $45 \mathrm{ft}$ per mile) (Winder and Sanford, 1972). The Algonquin Arch, the Michigan Basin, and the Allegheny Trough are structural elements that exerted facies control during the Silurian (Roliff, 1954; Liberty and Bolton, 1971). The study area lies between the Michigan Basin and the Allegheny Trough and is bounded to the west by the Algonquin Arch.

The Silurian outcrop belt in southern Ontario is bounded on the north and east by the Niagara Escarpment, a prominent topographical feature that rises $77 \mathrm{~m}(250 \mathrm{ft})$ above the Ordovician lowland in the Niagara Peninsula. Differential erosion of Upper Ordovician and Silurian strata produced this cuesta. Sandstone, shale, and carbonates of the Lower Silurian Cataract Group occur near the base of the escarpment.

The Cataract Group is underlain by the Upper Ordovician Queenston Formation throughout most of southern
Ontario. Consisting predominantly of red shale and siltstone, the Queenston Formation represents a deltaic sequence derived from the Taconic orogen to the east. Late Ordovician glaciation in the southern hemisphere initiated glacio-eustatic drawdown at this time and produced an unconformity that marks the close of the Ordovician throughout most of North America (Berry and Boucot, 1973; Boucot, 1975; Dennison, 1976).

The Whirlpool Formation contains the oldest Silurian strata in the Niagara Peninsula and is the lowest member of the Cataract Group in this area. This formation consists of white and grey, crossbedded, and ripple-marked orthoquartzitic sandstone resulting from an Early Silurian transgression. The Whirlpool Formation grades eastwards into coarse deltaic clastics of the Medina Group in New York State. The Medina Group grades rapidly westwards in Ontario into marine carbonates and shales represented by the Manitoulin and Cabot Head formations (Text-fig. 2). Deltaic redbeds of the Grimsby Formation complete the Cataract Group as a single transgressive-regressive

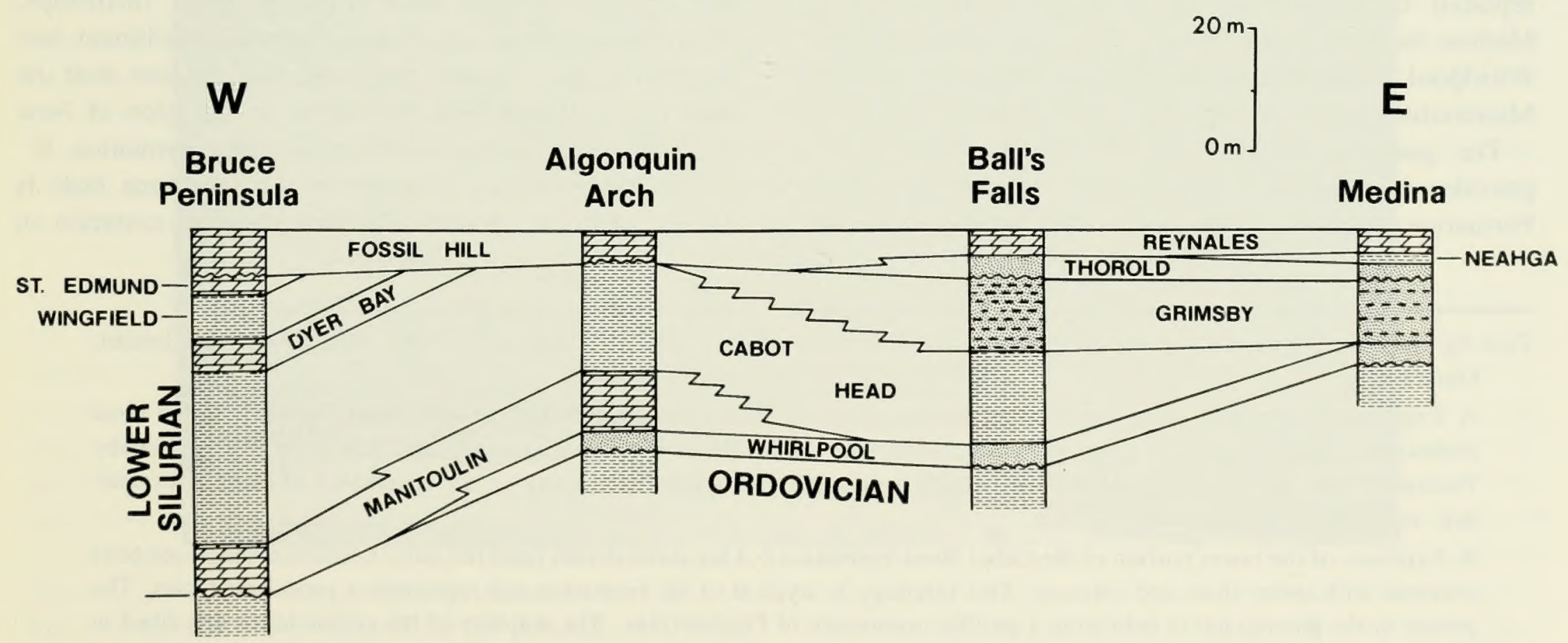

Text-fig. 2 Facies relationships of Lower Silurian formations in southwestern Ontario and western New York State. These strata disconformably overlie the Upper Ordovician Queenston Formation. Modified from Winder and Sanford (1972). 
cycle in the Niagara Peninsula, and time-equivalent platform carbonates occur on the Bruce Peninsula (Bolton, 1957).
During Early Silurian time, southern Ontario was situated at $20^{\circ}-25^{\circ}$ south of the equator, a latitude that indicates a subtropical environment (Ziegler et al., 1977).

\section{Stratigraphy of the Cabot Head Formation}

In the western Niagara Peninsula, the Cabot Head Formation consists of green, bluish grey, and red calcareous shale and interbedded grey and greenish grey argillaceous and arenaceous limestone from one to several centimetres in thickness. In the eastern Niagara Peninsula, however, an atypical facies is well developed. In this area the Cabot Head Formation consists of dark grey to green, fissile, calcareous to arenaceous shale and siltstone, and interbedded light grey to green, fine- to medium-grained calcareous sandstone (Bolton, 1957). The term Power Glen Formation was proposed for these strata by Bolton (1953). Recently, the Ontario Geological Survey has extended the name Cabot Head Formation to this area, indicating that there is no major lithological change in these strata (P. G. Telford, pers. comm., 1980). In the opinion of the writer, these strata are lithologically distinct from those of the Cabot Head Formation to the north but are restricted in nature. In this report they are considered to be a prodeltaic facies of the Cabot Head Formation. However, equivalent strata in the United States are still referred to as the Power Glen Formation, and the American Medina Group is equivalent to the Canadian Cataract Group.

The Cabot Head Formation crops out near the base of the Niagara Escarpment and averages $34 \mathrm{~m}$ in thickness in the Bruce Peninsula (Liberty and Bolton, 1971). These strata thin gradually south and east of this area and are replaced by redbeds of the Grimsby Formation near Medina in New York State. These strata overlie the Whirlpool Formation in the Niagara Peninsula and the Manitoulin Formation north of Stoney Creek.

The gorge at Ball's Falls on Twenty Mile Creek provides a complete section $(15 \mathrm{~m})$ of the Cabot Head Formation. A prodeltaic facies is well developed at this locality. The upper half of the formation is exposed at the base of the lower falls, and the remainder in a high bank $0.4 \mathrm{~km}$ downstream (Text-fig. 3A, B). The lower contact is gradational and is marked by a $25-\mathrm{cm}$-thick zone of shale and bioturbated sandstone beds that contain fragments of Lingula. Massive, crossbedded, ripple-marked sandstone of the Whirlpool Formation occurs below this interval. A similar gradational zone is present at DeCew Falls, $15 \mathrm{~km}$ to the east (Bolton, 1957).

The section downstream from Ball's Falls consists predominantly of interbedded sandstone, shale, and siltstone (Text-fig. 3B). The ratio of shale to sandstone increases upwards in the section, and the upstream exposure consists mostly of shale (Text-fig. 3A). The sandstone beds are light grey to greenish in colour, and up to $0.6 \mathrm{~m}$ in thickness. They tend to be lenticular and are rarely continuous laterally for more than $10 \mathrm{~m}$. Crossbedding and megaripple structures are present. A unit occurring approximately $1 \mathrm{~m}$ above the base of the formation at Ball's Falls contains megaripple structures that have a maximum amplitude of $0.5 \mathrm{~m}$ and a wavelength of $4.5 \mathrm{~m}$. These megaripples attenuate rapidly to the west (upstream) and are replaced by asymmetrical interference ripples with an amplitude of $2 \mathrm{~cm}$.

A unit with well-developed load casts is present about $2 \mathrm{~m}$ above the lower contact at Ball's Falls. Sandstone "pillow" structures up to $0.4 \mathrm{~m}$ in width occur in this unit and appear to have been produced by a thixotropic deformation (slumping) of water-saturated sediment into underlying mud. Similar structures may be seen near the base of the Power Glen Formation at Lewiston in New York State, and in the overlying Grimsby Formation.

The lower contact of many of the sandstone beds is abrupt. Obstacle, prod, and bounce marks are common on

Text-fig. 3A, B Echinoderm occurrences in the Cabot Head Formation at Ball's Falls on Twenty Mile Creek near Jordan, Ontario.

A Exposure of the Cabot Head and Grimsby formations at the base of the lower falls. The uppermost $7 \mathrm{~m}$ of the Cabot Head Formation, which consists of shale, siltstone, and minor sandstone, is overlain by crossbedded sandstone of the Grimsby Formation near the top of the photograph. The person in the photograph is standing on the occurrence of Cataractocrinus gen. nov. and of Kylixocrinus gen nov.

B Exposure of the lower portion of the Cabot Head Formation $0.4 \mathrm{~km}$ downstream from the falls. Lenticular sandstone beds alternate with softer shale and siltstone. This lithology is atypical of the formation and represents a prodeltaic facies. The person in the photograph is indicating a prolific occurrence of Ptychocrinus. The majority of the echinoderms described in this report were obtained from this exposure 

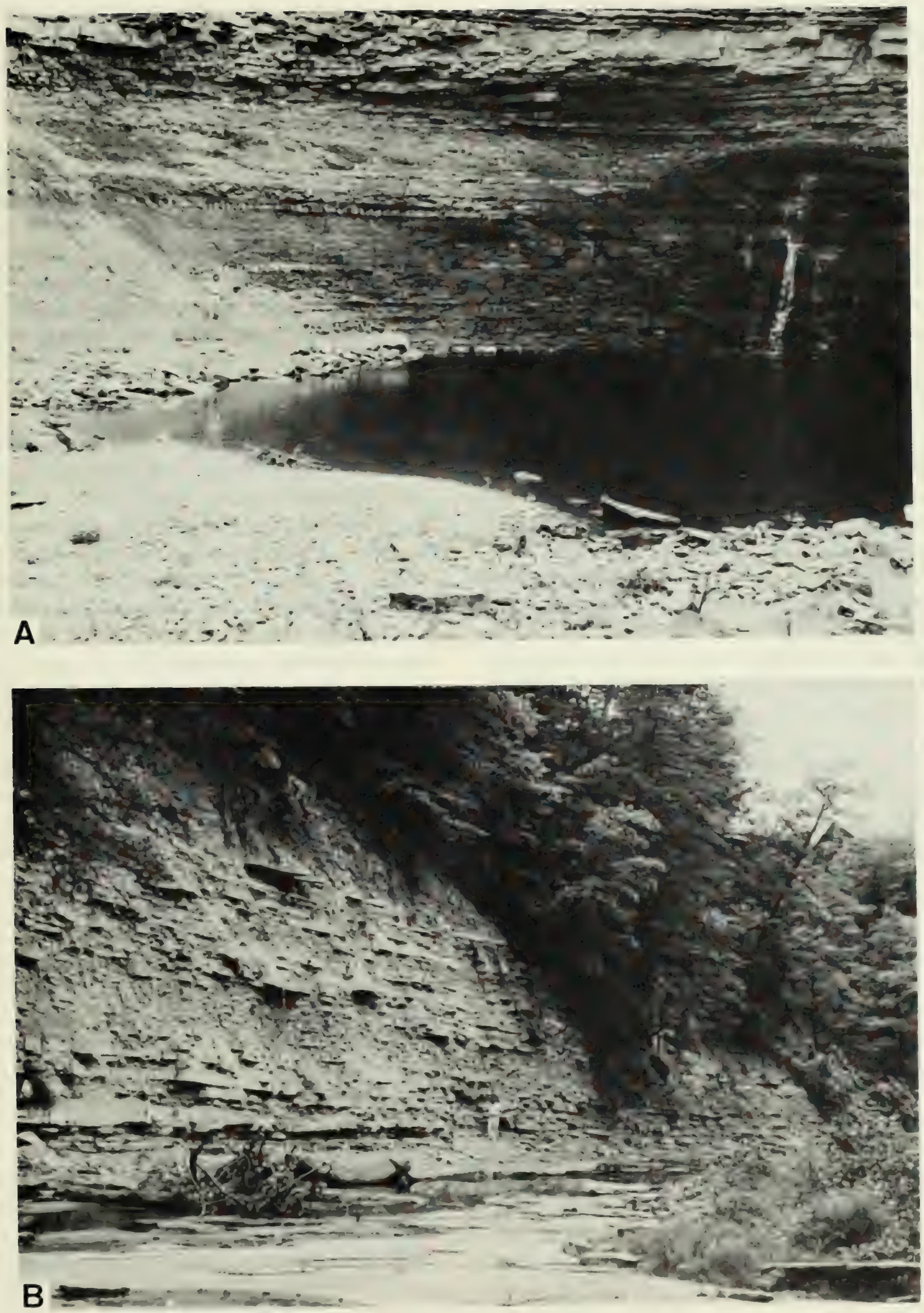
the undersides of these beds and appear to have been formed by the grounding of debris on soft substrates. Ripple marks may be present on the upper surfaces, but most are smooth and featureless. Certain layers are extensively bioturbated, obliterating the depositional fabric. The bioturbation features include structures probably made by annelids, trilobites, and gastropods.

Petrographic studies (Bolton, 1957; T. Iannelli, pers. comm., 1980) indicate that subangular to subrounded quartz grains constitute 60 to 70 per cent of the sandstone beds. The grains are consistently finer than those of the Whirlpool Formation. The size of these grains tends to decrease upwards through the formation. The lower beds are moderately well sorted, whereas the upper beds are typically well to very well sorted ( $T$. Iannelli, pers. comm., 1980). Carbonate cement comprises 10 to 25 per cent of the rock. Accessory minerals include microcline (less than 2 per cent), plagioclase, pyrite, magnetite, sphene, apatite, zircon, tourmaline, and carbonaceous matter.

Shale and siltstone are important constituents of the Cabot Head Formation at Ball's Falls. The shale is dark grey to blue or greenish, soft, and fissile, and disintegrates rapidly on exposure. Approximately 85 per cent is composed of clay minerals, 8 to 10 per cent of detrital quartz, 4 per cent of calcite cement, and less than 2 per cent of pyrite and carbonaceous matter (Fisher, 1954). Siltstone tends to occur in graded bed sequences at this locality,

The upper contact with the overlying Grimsby Formation at Ball's Falls is gradational and is indicated by red shale and sandstone. The Cabot Head Formation at DeCew Falls contains fewer and thinner sandstone beds than at Ball's Falls.

Equivalent strata in the Power Glen Formation are well exposed on the eastern side of the Niagara Gorge near Lewiston, New York (Text-fig. 4B). This section is thinner $(11 \mathrm{~m})$ than the Ball's Falls section and differs considerably in lithology. The beds that are gradational with the underlying Whirlpool Formation are thinner, and the lower third of the section consists mostly of silty shale. A fossiliferous, light bluish grey calcareous sandstone occurs $2 \mathrm{~m}$ above the base. A $1.5 \mathrm{~m}$ section of fossiliferous, yellowish grey, sandy and silty phosphatic dolomite is present $7 \mathrm{~m}$ above the base (Fisher, 1954). Whitish grey, fine- to medium-grained calcareous sandstone characterizes the upper part of the formation at this locality.

From Lewiston the Power Glen Formation thins rapidly eastwards, and it is only $6 \mathrm{~m}$ thick at Lockport, New York, $30 \mathrm{~km}$ east of the Niagara River. At Lockport the lowest metre contains numerous lenticular beds of impure sandstone, which is poorly sorted and coarser than in sections to the west. Thin sandstone beds are also common in the gradational zone near the top of the formation. Siltstone with minor shale comprises the remainder of the Lockport section.

Near Medina, $25 \mathrm{~km}$ east of Lockport, both the Whirlpool and Power Glen formations grade laterally into redbeds of the Medina Group, which are difficult to differentiate from Upper Ordovician strata of the Queenston Formation.

\section{Age of the Cataract Group}

The lowest Silurian rocks of North America are difficult to date (Berry and Boucot, 1970). These strata commonly lack diagnostic graptolites and brachiopods that permit correlation with European sections. Bolton (1957) observed that the fauna of the Cataract Group is largely restricted to the Michigan Basin. The Cataract Group does not contain the Hirnantian brachiopod fauna that is useful in delineating the Ordovician-Silurian boundary in many areas of Europe, Asia, Africa, and North America (Lespérance, 1974).

Brachiopods and conodonts have been used to determine the age of the Cataract Group. The Manitoulin Formation is shown to be of pre-Late Llandoverian age by the absence of Cyrtia, Eospirifer, Atrypa "reticularis", Eocoelia, and Resserella elegantula (Berry and Boucot, 1970). On Manitoulin Island, the few centimetres at the base of this formation contain the brachiopod Zygospirael$l a$, an index genus for Lower Llandoverian strata on the Siberian platform and in the Baltic area (Copper, 1978,
1982). The lowest Manitoulin portion contains the conodont Panderodus simplex, also suggestive of an Early Llandoverian age (Rexroad and Rickard, 1965; Pollock et al., 1970). The occurrence of the conodonts Spathognathodus celloni and $O$ zarkodina adiutricus places the upper portion of the Manitoulin Formation within the celloni irregularis Zone of the Middle Llandovery.

The Cabot Head Formation is considered to be highly diachronous (Winder and Sanford, 1972). The lower and middle Cabot Head in the Bruce Peninsula are of Middle Llandoverian age $\left(\mathbf{B}_{1}-\mathbf{B}_{3}\right)$ as indicated by the occurrence of the pentamerid Virgiana (Berry and Boucot, 1970). The uppermost Cabot Head in this area appears to be of early Late Llandoverian age $\left(\mathrm{C}_{1}-\mathrm{C}_{2}\right)$, a dating suggested by the occurrence of "Camarotoechia winiskensis" and "Plectatrypa" lowi in the overlying St. Edmund Formation (Berry and Boucot, 1970). The intergradation of the Cabot Head Formation with the Manitoulin, Dyer Bay, and St. Edmund formations to the west and north, and with the 
Grimsby Formation to the south and east indicates that the Cabot Head becomes progressively older to the south and east. This is probably also true of the underlying
Whirlpool Formation; which was deposited by a southeastern- to northwestern-migrating strand line.

\section{Age of Lower Silurian Crinoid Faunas}

Intergradation of the Manitoulin and Cabot Head formations and the disappearance of the former near Hamilton, Ontario, suggest that in the Niagara Peninsula the lower Cabot Head is the equivalent of the lower portion of the Manitoulin Formation, previously shown to be of Early Llandoverian age. Since the lower Cabot Head in the eastern Niagara Peninsula yielded most of the crinoids described in this report, the writer considers this fauna to also be of Early Llandoverian age. The antiquity of this Silurian assemblage is also suggested by the close relationship of the crinoid fauna to Ordovician genera. Cataractocrinus clementi gen. et sp. nov., Homocrinus diminutus sp. nov., Pariocrinus heterodactylus gen. et sp. nov., and Ptychocrinus medinensis are closely related to Ordovician forms. The nonechinoderm fauna from this assemblage also supports this view. Fisher (1954) considered that fossils collected from calcareous sandstone beds $2 \mathrm{~m}$ above the base of the Power Glen Formation in the Niagara Gorge probably represented the oldest known Silurian fossil assemblage in North America. A close relationship to Upper Ordovician faunas was suggested by the gastropod Cyclonema cf. bilix and the scolecodont Oeninites serratus.

The fauna of the Cataract Group is closely allied to the Lower Silurian Edgewood and Brassfield faunas of the east-central United States. Forty-two species of bryozoans and brachiopods are common to both areas (Savage, 1917; Johnson, 1934). The Brassfield Limestone has also produced a small crinoid fauna (Rowley, 1904; Foerste, 1919, 1936). Calceocrinus is at present the only crinoid known to occur in both the Cabot Head Formation and the Brassfield Limestone. This marked difference in crinoid faunas is probably a reflection of the different depositional environments of these units. The Cabot Head Formation in the eastern Niagara Peninsula was produced by the deposition of clastics in a prodeltaic environment, whereas the Brassfield Limestone was deposited in a higherenergy-platform environment characterized by the accumulation of carbonates. Current study of Brassfield echinoderms (Ausich, pers. comm., 1983) should clarify these relationships.

The Brassfield Limestone is probably slightly younger than the Cabot Head Formation. Conodont studies (Rexroad, 1967) indicated that the Brassfield is of Middle Llandoverian age. The uppermost Brassfield contains Microcardinalia, indicative of an early Late Llandoverian age (Berry and Boucot, 1970). Amsden (1974) placed the Ordovician-Silurian boundary within the Edgewood Group, which underlies the Brassfield in Missouri.

The Pentland Hills of Scotland have yielded a small crinoid fauna (Brower, 1975). This fauna also occurs in a clastic facies and resembles that of the Cabot Head Formation in several respects. The genera Dendrocrinus, Ptychocrinus, and Macrostylocrinus are common to both occurrences. The similarity of these faunas is a reflection of similar depositional environments. The Pentland Hills fauna, however, is younger than that of the Cabot Head Formation. The strata are currently assigned to the crenulata Zone of the latest Llandovery (Cocks et al., 1971).

The Hopkinton Dolomite of Iowa has proven to be the most prolific source of Llandovery crinoids yet discovered (Witzke and Strimple, 1981). This assemblage is of Late Llandoverian age, considerably younger than the assemblage described in this report (see p. 54 for discussion).

\section{Depositional Environment of the Cabot Head Formation at Ball's Falls}

Bolton (1957) interpreted these strata as an offshore facies characterized by a minimum of lime deposition, and he suggested that the faunal assemblage was indicative of a shallow, muddy, marine environment. Lateral replacement of the Cabot Head and Power Glen formations by coarser redbeds of the Medina Group to the east and by carbonates to the west indicated a sediment source from the southeast. Bolton noted that the mineralogy of the sandstone beds was similar to that of the underlying Whirlpool Formation, also derived from the southeast as indicated by grain size and sorting parameters (Gietz, 1954). A replacement of shale by siltstone in the Lockport area and a southerly increase in sandstone content of outcrops of the Power Glen Formation along the east side of the Niagara Gorge are also indicative of a source of sediment to the southeast.

Martini (1971) proposed a deltaic depositional model for the Cataract and Medina Groups. The Niagara Escarpment in westem New York State and southern Ontario represents an oblique cross section of the delta 
front. A major constructive phase of the deltaic sequence is recorded by red, unfossiliferous, channel-fill sandstones present in sections between Medina and Rochester. These strata are inferred to represent a flood-plain to high-tidalflat palaeoenvironment. Deeper sublittoral sediments were also being deposited farther west, in the Lockport area, at this time. These include the sparsely fossiliferous, grey to green sandstone and siltstone of the Power Glen Formation that contain rugose corals, brachiopods, and crinoids (Fisher, 1954). The transition from high-energy environments in the east is indicated by progressively finer clastics and the introduction of platform carbonates in the Hamilton area of southern Ontario.

Martini (1971:1252, fig. 3) recognized a prodeltaic facies within the Cabot Head Formation in the eastern Niagara Peninsula. This facies is restricted in occurrence and is typically developed in the DeCew Falls to Ball's Falls area only. Interbedded sandstone comprises almost one-third of the lower Cabot Head Formation in this area, a proportion that is anomalously high when compared to adjacent localities. The writer interprets this atypical facies as representing reworked distributary sediments that were deposited in the prodeltaic zone of a locally northward-extending lobe of the Medinan deltaic complex. This interpretation is supported by the presence of reworked distributary channels in the overlying Grimsby Formation at both DeCew Falls (Martini, 1971) and Ball's Falls (Text-fig. 4A). At the latter locality, massive, crossbedded, red-and-white-mottled sandstone forms a pod-shaped body that bows downwards into underlying shale. This structure has a maximum thickness of $4 \mathrm{~m}$ and an exposed width of $40 \mathrm{~m}$ and contains Lingula fragments and intraformational conglomerate. Orientations of flute casts on the underside of this sandstone structure indicate a southeastward-to-northwestward flow regime consistent with Medinan trends. The occurrence of abundant interbedded sandstone in the Cabot Head Formation below the channels at the two localities suggests derivation from distributary sands supplied to a deeper, sublittoral environment. Palaeocurrent data derived primarily from sole markings of these sandstone beds reveal a predominantly westward trend (Bolton, 1957; T. Iannelli, pers. comm., 1980). Orientations within a single bed tend to be consistent but may vary considerably from horizon to horizon. Northwestern, southwestern, and eastern trends also occur. These trends are not consistent with those of the distributary channels and suggest that in the Ball's Falls area longshore currents reworked deltaic clastics into submarine sandbars.

At Ball's Falls, interbedded sandstone decreases in abundance towards the top of the Cabot Head Formation, indicating that depositional energy gradually declined. The sandstone becomes finer grained near the top of these strata and is better sorted there, which supports this interpretation. These features may be correlated with the increasing areal extent and the deepening of the Early Silurian sea. As the distance from eastern shorelines increased, only finer clastics were normally transported as far west as the present-day Ball's Falls area. High-angle crossbedding, megaripple structures, and other features indicative of high-energy deposition are largely restricted to the lower beds of the Cabot Head Formation at Ball's Falls. Small, impure carbonate lenses near the middle of the formation at Ball's Falls and a 1.5-m-thick bed of phosphatic dolostone in the Niagara Gorge section indicate that clastic input from the southeast declined as the sea reached its maximum extent.

The Cabot Head Formation contains a rich and varied fauna of fossil marine invertebrates at Stoney Creek and in areas north of this locality (Bolton, 1957). In the eastern Niagara Peninsula and in the Power Glen Formation in western New York State, however, these strata are sparsely fossiliferous. Ichnofauna and the meagre assemblages reported by Fisher (1954) and Bolton (1957) are largely derived from interbedded sandstone, siltstone, and carbonates within these strata. Typical fossils include the brachiopods Resserella, Fardenia, and Leptaena; the gastropod Hormotoma; pelecypods Ctenodonta and Modiolopsis; and the bryozoan Helopora fragilis. Intervening shales are fissile and almost completely devoid of fossils, suggesting a lack of organic activity over much of the sea floor (Brett, 1978a). Brett interpreted the abundance of pyrite in these shales to be indicative of reducing conditions and postulated that there was little agitation near the sea floor. The greenish colour of much of the Cabot Head and Power Glen formations, which is owing

Text-fig. 4A, B Exposures of Lower Silurian strata in the Niagara Peninsula and vicinity.

A In the centre can be seen a large palaeodistributary channel located near the base of the Grimsby Formation at Ball's Falls. The structure has a maximum thickness of $4 \mathrm{~m}$ and an exposed width of $40 \mathrm{~m}$. The channel-fill deposits consist of massive, crossbedded sandstone and intraformational conglomerate, which cut downwards into underlying shale to a depth of approximately $1 \mathrm{~m}$. The covered interval below the channel is largely made up of the Cabot Head Formation.

B Exposure of the Medina Group on the east side of the Niagara Gorge at Lewiston, New York. The Power Glen Formation lies between the arrows. It overlies sandstone of the Whirlpool Formation in the foreground and is succeeded by the Grimbsy Formation. The Cabot Head Formation is $11 \mathrm{~m}$ thick at this locality. 

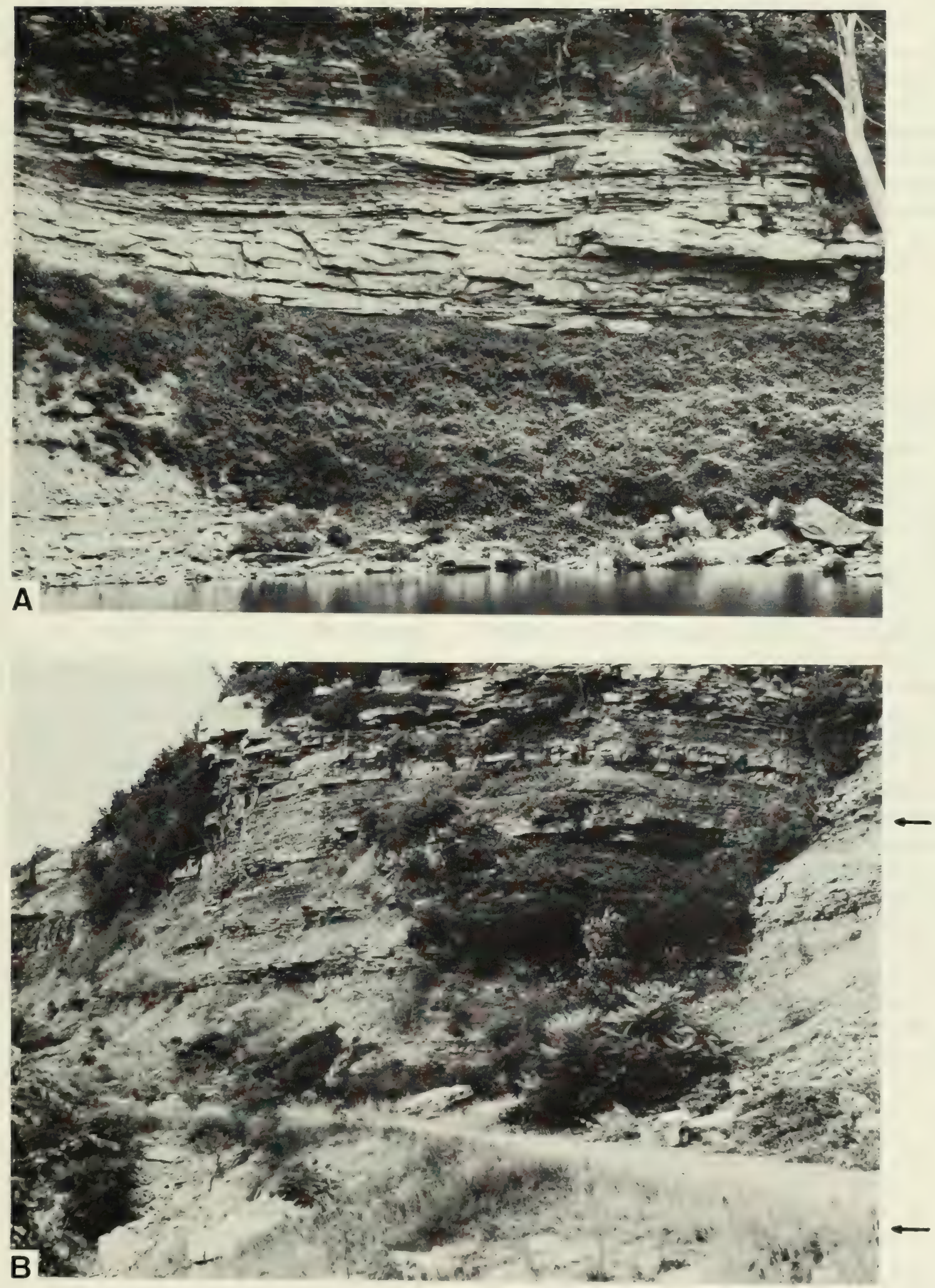
in part to iron in a ferrous state, and the associated small amounts of finely comminuted carbonaceous matter may indicate original reducing conditions. Alternating red and green coloration, produced by intergradation with the Grimsby Formation, suggests that oxidized deltaic sediments were reduced once they had been transported into a sublittoral regime.

Occurrences of well-preserved echinoderms at Ball's Falls are evidence that variable rates of sedimentation took place during deposition of the prodeltaic facies. These conditions were probably the result of variation in the amount of clastic sediments available owing to seasonal changes, storms, and changing distributary patterns. This hypothesis is supported by graded bedded sequences and the laminated texture of interbedded sandstone. Calcareous laminae may have been associated with decreased flow rates, a decrease in clastic input, and less sediment in suspension. Rates of sedimentation and turbidity levels were probably higher when flow rates increased.

\section{Occurrence and Preservation of the Echinoderm Fauna}

Exposures of the Cabot Head Formation at Ball's Falls yielded the majority of crinoids described in this report. Areas east of this locality produced few echinoderms despite careful investigation, suggesting that the apparently localized occurrence is not the result of collecting bias. However, abundant echinoderm debris present in the Manitoulin and Cabot Head formations indicates that suitable, and probably better, growth conditions prevailed to the west and north. The fine preservation of crinoids at Ball's Falls may reflect a facies-controlled preservational bias. These echinoderms are thought to represent biocoenoses that were a result of rapid, catastrophic burial. Preservation of this kind is typical in the prodeltaic facies only. Echinoderm debris present in platform carbonate facies to the west and north of Ball's Falls may indicate that slower, more uniform rates of sedimentation prevailed in these areas.

Occurrences of well-preserved crinoids at Ball's Falls are distinctly patchy and represent small stands or colonies of these organisms. They were found typically on the upper surfaces of sandstone lenses or within thin beds of siltstone. Each stand contained from a few to several hundred or more individuals. Most occurrences yielded fewer than 30 crinoid specimens and also contained a small nonechinoderm fauna. The preservation of crinoids in these stands is exceptional. Complete crowns are common, and some individuals retain the entire column and holdfast. In these instances little to no post-mortem transport is indicated. Modern crinoids decay rapidly after death and are thoroughly disarticulated within five to ten days of exposure (Meyer, 1971; Liddell, 1975). In the examples cited above, a covering layer of sediment inhibited disarticulation by decay, currents, and epifaunal scavengers.

Not all echinoderms in the prodeltaic facies are well preserved. Abraded, broken columnals are widely scattered at several horizons, suggesting prolonged exposure on the sea floor during periods of slow sedimentation and reworking of sediment containing ossicles. This type of preservation is common in the Cabot Head Formation. Most ossicles occur on the undersides of sandstone beds, possibly as a result of winnowing by currents. They may also occur in ripple troughs on the upper surfaces of these lenses. In one instance an occurrence of Nexocrinus gen. nov. was observed on the underside of a sandstone bed. The following series of biostratinomic events is postulated for this unusual occurrence. (1) Initially, these crinoids probably colonized a sandy substrate. (2) Several years later, they were torn away from their living site and swept along the substrate during a period of strong current activity. (3) Near the edge of the body of sand they became mired in soft mud and were rapidly buried by resuspended sand derived from the adjacent lens.

Many crinoids obtained from Ball's Falls are preserved as individuals flattened on bedding planes with the stem-crown axis directed horizontally. Individuals of the new genera Cataractocrinus, Nexocrinus, and Pariocrinus are typically preserved in this manner. Crowns of Kylixocrinus gen. nov, are preserved in an unusual manner. Each individual is typically inverted with the tegmen directed downwards into a siltstone matrix. The arms are spread out in a single bedding plane at about $90^{\circ}$ relative to the stem-crown axis, producing a radiating sunburst pattern. The pinnule fans of each arm are oriented at about $180^{\circ}$ to each other (PI. 1, fig. 4, ROM 38988a). Long lengths of the columns attached to these crowns were discovered on bedding planes immediately above the arms. By analogy with modern forms, these patelliocrinid camerates are thought to have been buried while feeding in a rheophilic manner (see Brower, 1973:270 for similar occurrence).

Crowns of Ptychocrinus recovered from a large stand are preserved in an unusual orientation. In a sample of 45 specimens, 43 individuals are preserved in an inverted position. In this orientation, the arms are typically preserved in a fanlike arrangement that is directed to one 
side of the cup, unlike the symmetrical orientation of arms present in Kylixocrinus. Furthermore, the arms penetrate downwards into the matrix at a shallow angle.

A scarcity of stem material is evident in the Ptychocrinus stand. Most individuals do not have attached columns. Flattened crowns preserved on bedding planes are an exception. Columns bearing distal coils (Ptychocrinus lacks a radix) are nonexistent in this occurrence.

The gastropod Naticonema is attached to the tegmen of most of these individuals (PI. 3, fig. 1). A coprophagous, commensal relationship is indicated (see pp. 50, 51 for discussion). However, the gastropod aperture is rarely positioned over the anal vent of its host in this stand.

Thin films of pyrite are present on many of the Ptychocrinus specimens. The pyrite is concentrated towards the base of the calyx, particularly in the area of the stem cicatrix and in sutures between plates. The arms and distal portions of the cup are notably free of this mineral.

The following series of events is postulated to account for the features observed in the Ptychocrinus stand. (1) An unusually strong current surge affected a large, mature stand of Ptychocrinus, separating most individuals from their stems. (2) The stand was transported en masse a short distance and rapidly buried by a thick blanket of silt. (3) The crinoid viscera began to decay, but covering sediment prevented disarticulation. (4) Buoying by decay gases caused the calyces to rotate to an inverted orientation, buckling the arms underneath the tegmen. Decay of the incompetent tegmen permitted each calyx to rotate relative to the attached gastropod, so that the gastropod aperture was no longer positioned over the anal vent of its host. (5) Once the calyces were inverted, a localized reducing environment was created by decay gases that collected near the base of each cup, causing syngenetic deposition of pyrite.

Ptychocrinus individuals preserved with short lengths of attached stem did not rotate as readily; perhaps the column acted as an anchor or drag.

Several dozen specimens of the asteroid Promopalaeaster? granti and of indeterminate ophiuroids were collected from megaripple troughs on interbedded sandstone near the base of the Cabot Head Formation at Ball's Falls.
Sandy substrates and a slow rate of subsidence following deposition of the underlying Whirlpool Formation appear to have provided an ideal environment for these organisms. High-angle crossbedding and large- and smallscale ripple structures suggest shallow-water, high-energy conditions. The concentration of individuals in megaripple troughs may have been the result of several processes. For instance, the stelleroids may have been seeking shelter from unusually strong currents, or they may have been swept into local depressions. The good preservation and the overturned position of many individuals is sound evidence of rapid burial accompanied by turbulence.

\section{DIAGENETIC ALTERATION}

Diagenetic alteration limits palaeontological investigation of the strata in which the echinoderms occur. All the crinoids collected have been dolomitized, and recrystallization has occasionally obscured plate sutures. The severity of this problem is dependent on the size of the affected organism and on lithotope association. Small, thin-plated forms, especially specimens of Nexocrinus gen. nov. and the discs of ophiuroids, tend to be severely recrystallized. Individuals preserved on sandstone are commonly recrystallized, while those collected from siltstone lenses are typically unaltered. This suggests that sediment porosity and permeability were controlling factors that governed recrystallization. None of the study material is preserved as hollow moulds, though certain small, inadunate calyces are not completely infilled with sediment.

Pyrite films are occasionally present on the crinoids and are probably of syngenetic origin, precipitated during the decay of the organisms. Subsequent decomposition etched and weakened plates, particularly in specimens of the new genus Kylixocrinus. These plates adhere loosely to the cups, and care must be taken during preparation. Groundwater solution may also have weakened plates and affected ornamentation.

Finally, most of the study material is preserved in a friable siltstone matrix that disintegrates readily upon wetting and drying. This made excavation and preparation of specimens difficult.

\section{Systematic Palaeontology}

\section{TERMINOLOGY}

The terminology used in the description of crinoids is that used by Moore et al. (1978). Terminology used in the description of asteroids is adopted from Spencer and Wright (1966) and Branstrator (1979).

\section{REPOSITORY}

All specimens, figured and unfigured, that form the basis of this report have been deposited in the collections of the Department of Invertebrate Palaeontology at the Royal Ontario Museum (ROM) in Toronto, Ontario, Canada. 


\section{Class Crinoidea Miller, 1821 \\ Subclass Camerata Wachsmuth and Springer, 1885 \\ Order Monobathrida Moore and Laudon, 1943 \\ Superfamily Patelliocrinacea Angelin, 1878 \\ Family Patelliocrinidae Angelin, 1878}

\section{Kylixocrinus gen. nov.}

TYPE SPECIES

Kylixocrinus latus sp. nov.

\section{ETYMOLOGY}

From the Greek kylix - a shallow cup - in reference to the low, bowl-like shape of the cup of this genus, and from the Greek krinon-lily.

\section{DIAGNOSIS}

Monotypic patelliocrinid with low, bowl-shaped aboral cup. Median ray ridges present. Interrays not depressed; CD-interray much wider than others. Radials largest plates in cup. Primibrachials two; fixed secundibrachials two or three. First interprimibrachial hexagonal, supporting two smaller plates. Primanal large, subequal, septagonal or octagonal, typically in contact with first primibrachial of D-ray, and bounded on right by smaller anal plate. Arms ten, pinnulate, biserial.

\section{DISCUSSION}

Kylixocrinus gen. nov, is closely related to Macrostylocrinus (see p. 16 for a discussion of Macrostylocrinus). The two genera differ primarily in the CD-interray area (Text-fig. 5). There are two anal plates in the first range on Kylixocrinus, in contrast to only one plate (the primanal) on many species of Macrostylocrinus. The primanal of Kylixocrinus is large and approximately the same size as the underlying radials whereas the primanal of Macrostylocrinus is typically much smaller. The primanal of Kylixocrinus is typically in lateral contact with the first primibrachial of the D-ray, but it is separated from the corresponding plate in the C-ray by a smaller anal plate that is supported by a septagonal radial. The primanal of Macrostylocrinus, in contrast, is commonly in lateral contact with the first primibrachials of the C- and D-rays, and its underlying radials are typically hexagonal. Kylixocrinus has smaller basals than does Macrostylocri-
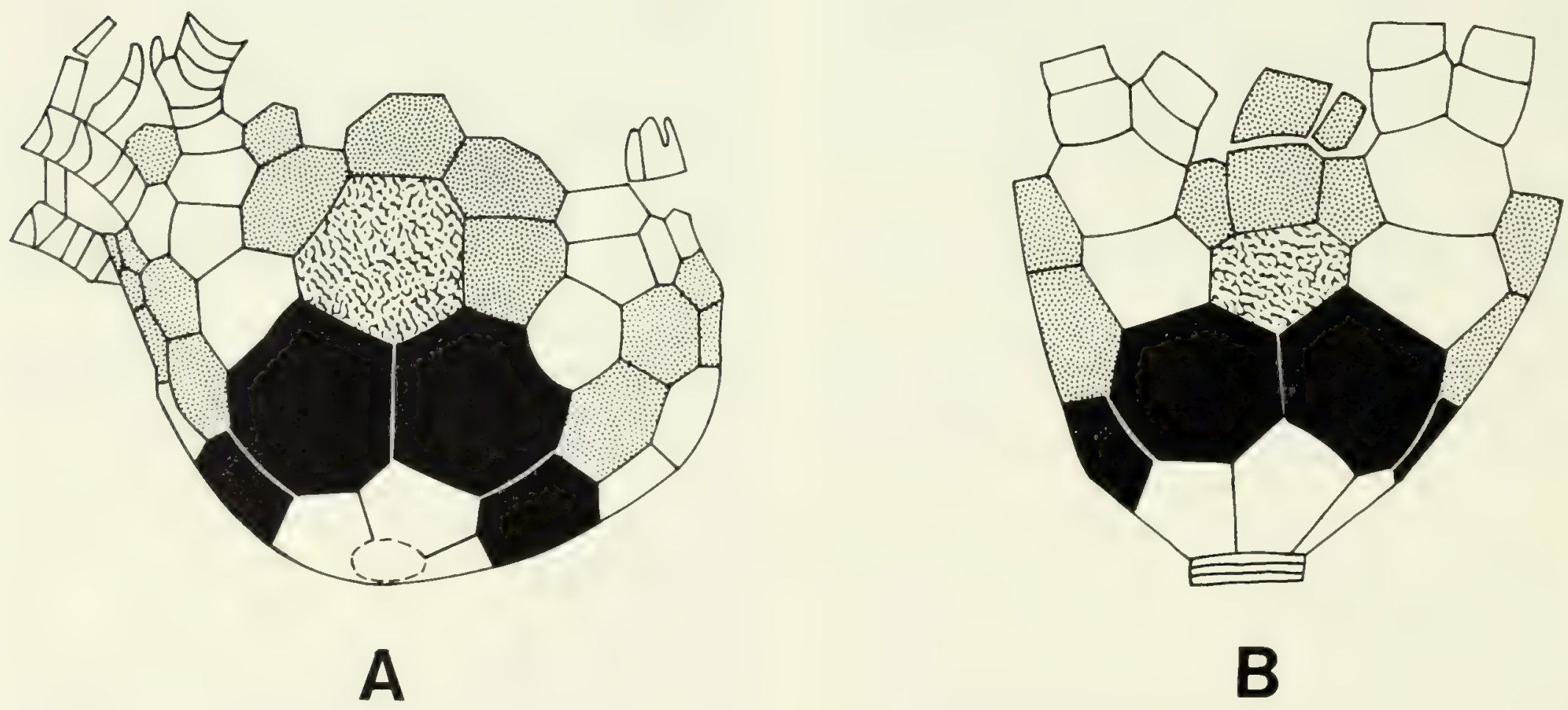

Text-fig. 5A, B CD-interray comparison of patelliocrinid genera.

Radials black; primanal wrinkle stipple; anals and interbrachials dot stipple. Scales $5 \mathrm{~mm}$.

A Kylixocrinus latus gen. et sp. nov. (holotype ROM 38987, Pl. 1, fig. 1; Pl. 2, fig. 1). Note anal plate to right of primanal, separating primanal from C-ray brachitaxis, and note greater width of posterior interray.

B Macrostylocrinus ornatus, type species of Macrostylocrinus (specimen figured by Springer, 1926, pl. 4, fig. 24). 
Table 1 Measurements (in $\mathbf{m m}$ ) of types of Kylixocrinus latus gen. et sp. nov.

\begin{tabular}{|c|c|c|c|c|}
\hline Measurements & $\begin{array}{c}\text { Holotype } \\
\text { ROM } 38987\end{array}$ & $\begin{array}{c}\text { Paratype } \\
\text { ROM 38988a }\end{array}$ & $\begin{array}{c}\text { Paratype } \\
\text { ROM } 38988 b\end{array}$ & $\begin{array}{c}\text { Paratype } \\
\text { ROM 38995t }\end{array}$ \\
\hline Aboral cup height & $9.0^{*}$ & $6.6^{*}$ & $11.0^{*}$ & $6.9 *$ \\
\hline Aboral cup width & $11.0^{*}$ & $10.0^{*}$ & $13.0^{*}$ & $10.0^{*}$ \\
\hline Basal height & 1.5 & - & 1.3 & - \\
\hline Basal width & 3.1 & - & 3.2 & - \\
\hline Radial height & 3.0 & 2.9 & 3.6 & 2.7 \\
\hline Radial width & 4.1 & 3.4 & 4.4 & 3.4 \\
\hline Primibrachial, height & 2.2 & 1.9 & 2.3 & 1.6 \\
\hline Primibrachial, $_{1}$ width & 2.7 & 2.4 & 3.1 & 2.4 \\
\hline Axillary, height & 1.5 & - & 1.7 & 1.4 \\
\hline Axillary, width & 2.9 & - & 2.4 & 2.2 \\
\hline Anal $\mathrm{X}$ height & 3.3 & - & 3.8 & - \\
\hline Anal $\mathrm{X}$ width & 3.3 & - & 3.7 & - \\
\hline Arm length & 40.0 & 28.0 & 38.0 & $18.0 * *$ \\
\hline Proximal stem diameter & - & - & 1.7 & - \\
\hline
\end{tabular}

* Measurement approximate owing to distortion of specimen.

** Distal portions of arms not preserved.

nus, and the low, bowl-shaped aboral cup of the former differs from the conical cup and depressed interrays of the type species $M$. ornatus Hall and of many other species assigned to Macrostylocrinus .

Kylixocrinus may have been derived from an Ordovician species of Macrostylocrinus through accelerated growth of the primanal. Potential ancestors include the Middle Ordovician species $M$. wyomingensis Kolata, and the Upper Ordovician species $M$. cirrifer Ramsbottom and $M$. pristinus Brower. $M$. cirrifer, a species from Scotland, resembles Kylixocrinus latus in that it possesses whorls of cirri along the column, and $M$. cirrifer inhabited a prodeltaic environment similar to that inferred for $K y$ lixocrinus. It is judged to be the most probable ancestor of Kylixocrinus.

\section{Kylixocrinus latus sp. nov.}

Text-fig. 5A; Text-fig. 6A-E; PI. 1, figs. 1-4; Pl. 2, figs. $1-6$

\section{TYPE MATERIAL}

Sixteen specimens were available for study: holotype ROM 38987; paratypes figured ROM $38988 \mathrm{a}$, b to 38990 inclusive, 38992, 38995a; paratypes unfigured ROM $38991,38993,38994,38995 b, 38996,39044$ to 39047 inclusive.

\section{OCCURRENCE}

Cabot Head Formation, $6.4 \mathrm{~m}$ above base, at Ball's Falls on Twenty Mile Creek near Jordan, Ontario.

\section{ETYMOLOGY}

From the Latin latus-broad-in reference to the wide CD-interray of this species.

\section{DIAGNOSIS}

As for genus.

\section{DESCRIPTION}

Height of crown approximately $60 \mathrm{~mm}$. Aboral cup bowl-shaped, approximately one and one-half to two times wider than high; sides nearly vertical at top of cup. Interrays inflated. CD-interray much wider than others. Narrow median ridges on rays, weakly to strongly developed in type specimens, extending upwards from basals. Ridges flare in aboral direction on basal and radial plates. Ridges ornamented with fine, distinct striae. Plates of cup ornamented with pustules that commonly coalesce, forming irregular, anastomosing ridges (PI. 1, fig. 1). Faint stellate ornamentation may also be present (ROM 38991). Basals three, small; basal circlet very low, visible in side view. Radials five, largest plates in cup, hexagonal or septagonal, subequal to slightly wider than high (Table 1), and in lateral contact. Radial circlet height about one-third that of cup. First primibrachial hexagonal, slightly wider than high; size approximately half that of radials. Second primibrachial smaller, wider than high, pentagonal, axillary, supporting two fixed secundibrachials (Text-fig, 6A-C). First secundibrachial hexagonal, wider than high. Second secundibrachial irregularly pentagonal or hexagonal, followed by free brachials. First 
interprimibrachial hexagonal, with size about equal to that of first primibrachial, and with distal upper edges level with those of adjoining first primibrachials. Each interprimibrachial supports two smaller plates of irregular pentagonal or septagonal form, the upper edges of which are approximately level with those of adjoining axillaries; smaller plates followed by two, or typically three, smaller, irregular polygonal plates in the next range (Text-fig. 6B, C; Pl. 2, figs. 2, 3). A few smaller, higher interprimibrachials may be present in adults. One or two intersecundibrachials present (Text-fig. 6F; Pl. 2, fig. 6). Primanal large, with size about equal to that of radials; primanal septagonal or octagonal, with height equal to width, and with distal edges at about same level as those of axillaries (Text-fig. 6A, F; Pl. 2, figs. 1, 6). Primanal typically in lateral contact with first primibrachial of D-ray but not with that of C-ray; right edge bounded by smaller, irregular, subequal anal plate, which is in contact with C-ray brachitaxis to axillary or first secundibrachial (Text-fig. 6A; Pl. 2, fig. 1). Primanal supports a series of at least three subequal polygonal plates, which become smaller distally, forming a distinct anal ridge in some individuals (PI. 1, fig. 4). Anal ridge flanked by smaller, irregular polygonal plates (Text-fig. 6F; PI. 2, fig. 6). Tegmen not observed. Arms ten, pinnulate, composed of rounded, wedge-shaped brachials. Proximal six to ten brachials of each arm form uniserial taxis; remainder in immature biserial arrangement. Narrow, deep groove present on adoral side of arm. Pinnules long, lath-shaped, composed of up to 20 pinnulars.

Stem heteromorphic, small, round, tapering distally. Proxistele and mesistele composed of alternating nodal and internodal columnals. Columnals low, with heights one-fifth to one-quarter of widths. Proxistele nodals display narrow epifacets; those of mesistele are downcurved. Lumen concavopentastellate, with width approximately one-quarter of stem diameter. Crenularium wide; 20 to 25 culminae present. Proxistele and mesistele bear slender cirri up to $3 \mathrm{~cm}$ in length ( $\mathrm{Pl}$. 1, fig. 3). Proxistele cirri arranged in irregular fashion; cirri of mesistele arranged in whorls, typically five cirri per whorl. Each cirrus borne by two or three columnals and composed of 40 to 50 cirrals. Lengths of proximal cirrals about one-half of widths; distal cirrals moderately elongated. Dististele not preserved.

\section{DISCUSSION}

The 16 specimens of Kylixocrinus latus gen. et sp. nov. available for study show considerable variation in the development of median ray ridges and anitaxial ridges, in the degree and type of ornamentation, and in the construction of the $\mathrm{CD}$-interray. The median ray ridges are typically low and become indistinct below the radials (holotype ROM 38987), but one individual has higher ridges that extend to the basals (ROM 38995a). A distinct anitaxial ridge is present in some specimens (ROM $38988 \mathrm{~b}$, 38995a) but absent in others (ROM 38987). The ornamentation of most individuals consists of pustules that commonly coalesce to form irregular anastomosing ridges. A faint stellate pattern of ridges may be superimposed on this ornament (ROM 38991). The construction of the CD-interray of the holotype is considered to be typical for the genus. In one individual, however, the anal plate to the left of the primanal (closest to the D-ray) extends downwards so that it is in narrow contact with the D-ray radial (paratype unfigured ROM 38993). This specimen is considered to represent a variant in a population of single species.

The lateral cirri borne by $K$. latus suggest a semipermanent mode of attachment to the sea floor (see p. 46 for discussion).

\section{Genus Macrostylocrinus Hall, 1852}

\section{TYPE SPECIES}

Macrostylocrinus ornatus Hall, 1852, by monotypy.

\section{DIAGNOSIS}

Patelliocrinid with conical to bowl-shaped aboral cup. $\mathrm{CD}$-interray wider than other interrays. Interbrachial areas depressed or inflated. Radials in lateral contact. Primibrachials two; second primibrachial axillary. One to three fixed secundibrachials present. First interprimibrachial usually hexagonal, followed by several higher ranges.

Text-fig. 6A-F Kylixocrinus latus gen. et sp. nov.

Radials black; primanal wrinkle stipple; anals and interbrachials dot stipple. Scales $5 \mathrm{~mm}$.

A CD-interray of holotype. Note asymmetric placement of primanal, which is bounded on right by a smaller anal plate. ROM 38987, Text-fig. 5A; Pl. 1, fig. 1; Pl. 2, fig. 1 .

B DE-interray of holotype ROM 38987, Pl. 2, fig. 2.

C Holotype centred on A-ray, ROM 38987, Pl. 2, fig. 3.

D CD-interray of paratype ROM 38992, Pl. 2, fig. 4

E Basal view of paratype RoM 38995 a, Pl. 2, fig. 5

F CD-interray of largest individual. Paratype ROM 38988 b, Pl. 1, fig. 4; Pl. 2, fig. 6 


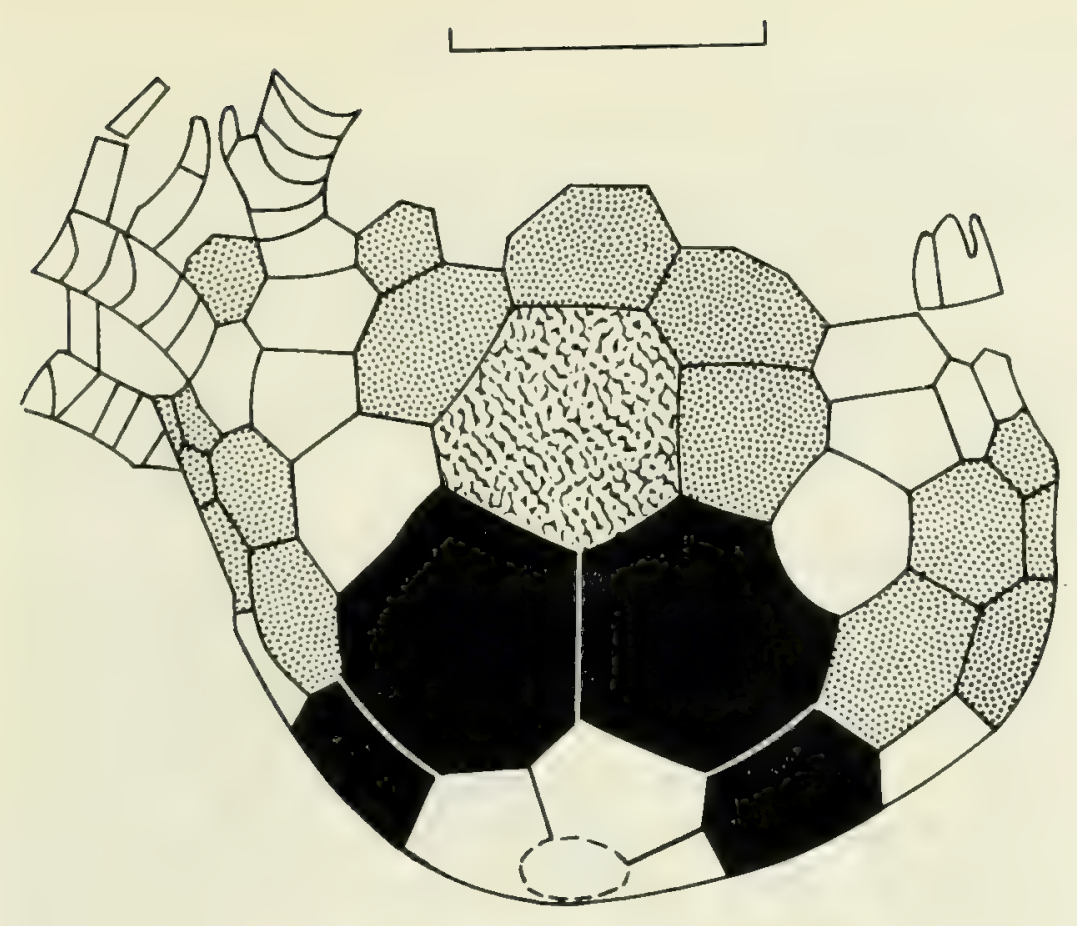

A
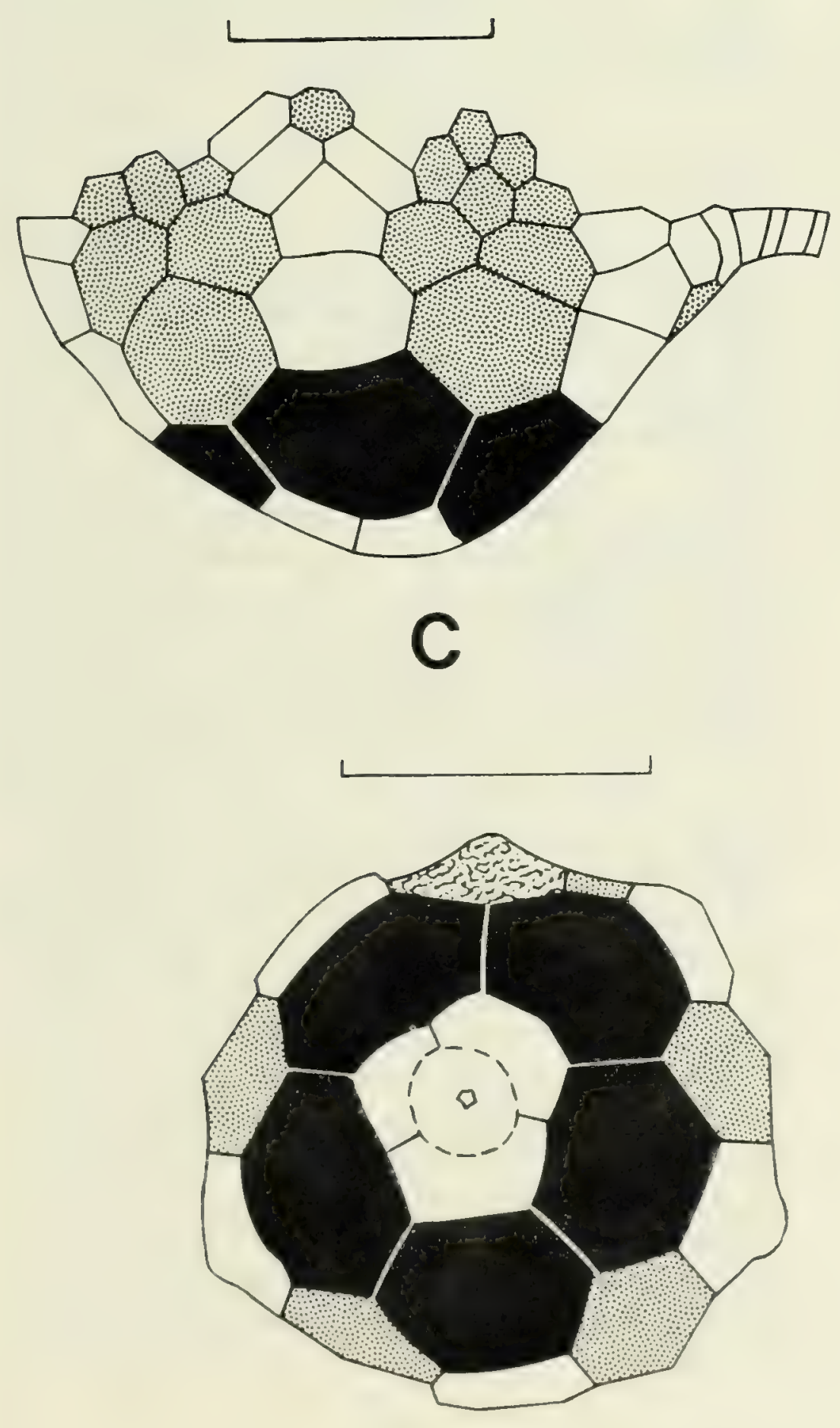

E

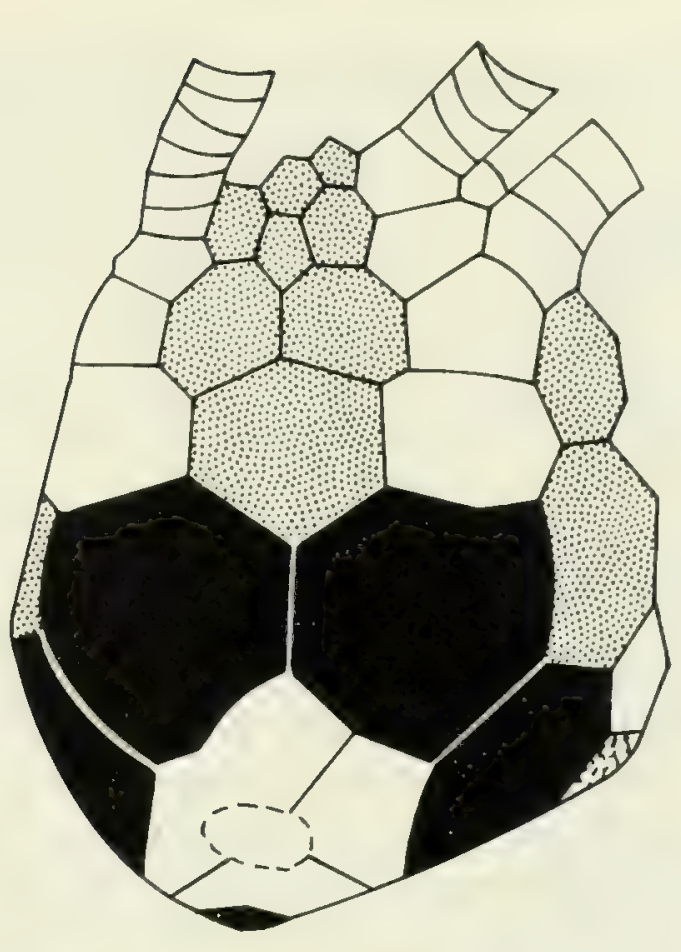

B
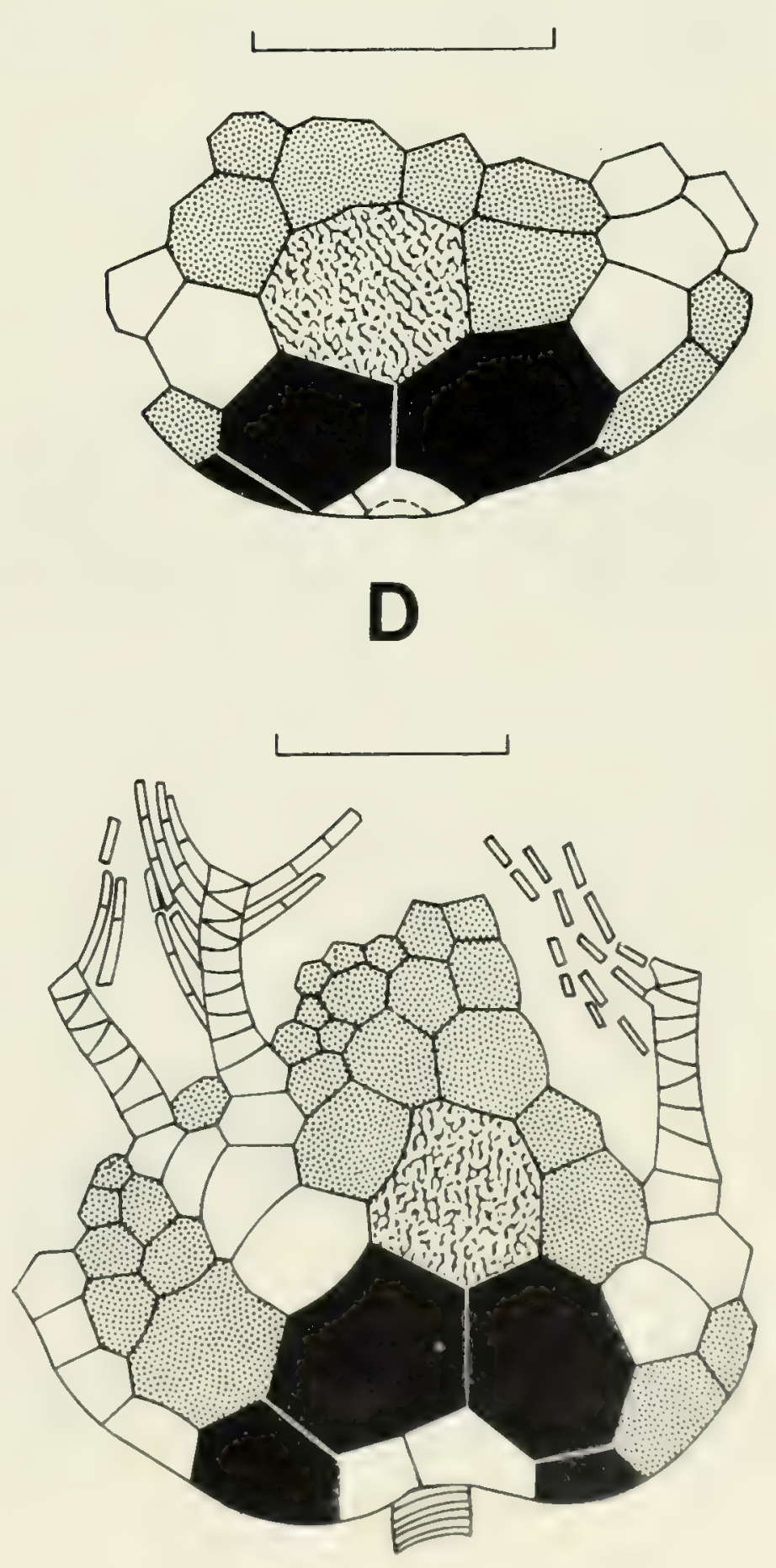

F 
Intersecundibrachials present or absent. Primanal typically in lateral contact with adjoining first primibrachials, supporting two to six plates, typically three, in next range. Anal ridge present or absent. Arms ten, biserial.

\section{KNOWN RANGE AND DISTRIBUTION}

Middle Ordovician to Upper Silurian, in North America and Europe.

\section{DISCUSSION}

Witzke and Strimple (1981) indicated that Macrostylocrinus includes a diverse group of patelliocrinids in need of taxonomic revision. Shapes of aboral cups at present include conical forms such as those of $M$. ornatus Hall and $M$. granulosus Hall, bowl-shaped forms including those of $M$. fusibrachiatus Ringueberg and M. meeki (Lyon), and the subcylindrical form of $M$. fasciatus Hall. The interrays of Macrostylocrinus are depressed or inflated. The sizes and shapes of the primibrachials show considerable intraspecific and interspecific variation. One to three fixed secundibrachials are present. Intersecundibrachials may be present ( $M$. pristinus) or absent ( $M$. ornatus). The interprimibrachials vary considerably in size and shape and are present in two to five or six ranges. The plates of the cup may be smooth or strongly tuberculate or striate. The construction of the CD-interray is especially variable among species currently assigned to Macrostylocrinus. The type species, $M$. ornatus Hall (Upper Silurian, Wenlock), typically has a small primanal that is in lateral contact with adjacent first primibrachials and that supports three plates in the next (higher) range. The primanal in other species such as $M$. fusibrachiatus Ringueberg is typically separated from the adjacent rays by smaller anal plates so that the posterior interray is much wider than the other interrays. Considerable variation may occur in individuals assigned to a single species. As an example, in specimens of $M$. laevis Springer the primanal may or may not be in lateral contact with the adjacent rays and it supports three to six plates. Specimens of $M$. granulosus Hall show similar variation (see Springer, 1926:180, 181, pl. 4, figs. 9-25 for illustrations of Macrostylocrinus).

The writer agrees that Macrostylocrinus needs taxonomic revision. However, careful study of the type species is needed to differentiate features of ontogenetic significance, intraspecific value, and higher taxonomic rank.

\section{Macrostylocrinus jordanensis sp. nov. Text-fig. 7; Pl. 10, figs. 6-8}

\section{TYPE MATERIAL}

Eight specimens were available for study: holotype ROM $38997 \mathrm{a}$; paratypes figured ROM 38998a, b; paratypes unfigured ROM 38997b, 38998c, 38999 to 39001 inclusive.

\section{OCCURRENCE}

Cabot Head Formation, $1.3 \mathrm{~m}$ above base, at Ball's Falls on Twenty Mile Creek near Jordan, Ontario.

\section{ETYMOLOGY}

The specific name refers to occurrences of this species near the village of Jordan.

\section{DIAGNOSIS}

Aboral cup small, cone-shaped. Plates smooth, unornamented. Interbrachial areas depressed. Basals small for genus. Primibrachials wider than high. One secundibrachial incorporated into cup. Interprimibrachials in two or three ranges. Primanal supports three smaller plates. Free brachials of immature biserial form. Stem round, bearing whorls of cirri.

\section{DESCRIPTION}

Height of crown approximately $35 \mathrm{~mm}$. Aboral cup conical with rounded sides; height equal to width. Interbrachial areas strongly depressed. CD-interray wider than other interrays. Cup plates smooth, unornamented. Basals three, small, unequal. Basal circlet low, about one-fifth of cup height. Radials five, largest plates in cup, hexagonal or septagonal, slightly wider than high (Table 2 ), and in lateral contact. Combined height of basal and radial circlets approximately one-half that of cup. First primibrachial small, rectangular to hexagonal, wider than high (Table 2; Pl. 10, figs. 6-8). This plate and succeeding axillary strongly arcuate in cross section, forming wide ranges on rays (Pl. 10, fig. 6). Axillary pentagonal to septagonal, wider than high (Table 2). First secundibrachial rectangular and incorporated into cup. First secundibrachials of each ray in lateral contact. Interprimibrachials in two or three ranges. First interprimibrachial hexagonal, subequal, with distal edges level with those of first primibrachials, and followed by two smaller, subequal, irregular plates that extend nearly to top of cup. One additional higher range of smaller plates present in some individuals. Intersecundibrachials not present. Primanal hexagonal, wider than high, in contact with adjoining rays, supporting three smaller plates followed by at least one higher range. Anal ridge not present. Arms ten, two per ray, tapering gradually distally, densely pinnulate. Proximal four to six free brachials cuneate, uniserial (Text-fig. 7; Pl. 10, fig. 6). Remaining free brachials in immature biserial arrangement. Each pinnule composed of up to ten elongate, lath-shaped pinnulars.

Proxistele bears whorls of cirri. Each cirrus borne by two or three columnals. Columnals round, narrow; at least two orders present. Mesistele and dististele not preserved. 
Table 2 Measurements (in $\mathbf{m m}$ ) of types of Macrostylocrinus jordanensis sp. nov.

\begin{tabular}{|c|c|c|c|c|}
\hline Measurements & $\begin{array}{c}\text { Holotype } \\
\text { ROM 38997a }\end{array}$ & $\begin{array}{c}\text { Paratype } \\
\text { ROM } 38997 \mathrm{~b}\end{array}$ & $\begin{array}{c}\text { Paratype } \\
\text { ROM 38998a }\end{array}$ & $\begin{array}{c}\text { Paratype } \\
\text { ROM } 38998 b\end{array}$ \\
\hline Aboral cup height & 6.1 & - & $5.4^{*}$ & $4.0^{*}$ \\
\hline Aboral cup width & $7.1^{*}$ & 8.6 & $7.1^{*}$ & $4.8^{*}$ \\
\hline Basal height & 1.4 & - & - & - \\
\hline Basal width & 2.1 & - & - & - \\
\hline Radial height & 2.1 & 2.4 & 2.5 & 1.3 \\
\hline Radial width & 2.9 & 2.8 & 2.7 & 1.5 \\
\hline Primibrachial $_{1}$ height & 0.89 & 1.5 & 0.76 & 0.76 \\
\hline Primibrachial $_{1}$ width & 1.8 & 2.3 & 1.2 & 1.0 \\
\hline Axillary, height & 0.94 & 1.3 & 0.71 & 0.74 \\
\hline Axillary, width & 1.5 & 1.9 & 1.1 & 1.0 \\
\hline Anal $X$ height & 0.86 & - & - & - \\
\hline Anal $X$ width & 1.5 & - & - & - \\
\hline Arm length & $18.0^{* *}$ & - & 23.0 & $16.0^{* *}$ \\
\hline Proximal stem diameter & - & 1.5 & - & - \\
\hline
\end{tabular}

* Measurement approximate owing to distortion of specimen.

** Distal portions of arms not preserved.

\section{DISCUSSION}

Macrostylocrinus jordanensis sp. nov. can be differentiated from the type species, $M$. ornatus, by several characteristics. $M$. jordanensis has smaller basals, lower primibrachials, more strongly depressed interrays, and free brachials in immature rather than mature biserial arrangement.

M. jordanensis is closely allied with $M$. wyomingensis Kolata (Middle Ordovician, Wyoming). The two species have few interbrachials, a similar construction of the CD-interray, and cirriferous stems. The rounded, conical cup of $M$. jordanensis differs from the wide, bowl-shaped cup of $M$. wyomingensis. The arms of $M$. wyomingensis are more massively constructed than those of $M$. jordanensis.

Witzke (1977) considered M. wyomingensis, known only from the holotype, to be a species of Allocrinus. However, Allocrinus typus Wachsmuth and Springer, the type species of Allocrinus, has stout arms that are composed of hyperpinnulated compound brachials, a feature unknown in Macrostylocrinus. The writer believes that $M$. wyomingensis should be retained in Macrostylocrinus pending discovery of additional specimens.

$M$. pristinus Brower and $M$. cirrifer Ramsbottom are the only other Ordovician species of Macrostylocrinus. $M$. pristinus possesses more numerous interbrachials than $M$. jordanensis and lacks a cirriferrous stem. The cup plates of $M$. jordanensis lack the nodose ornamentation of those of $M$. cirrifer.

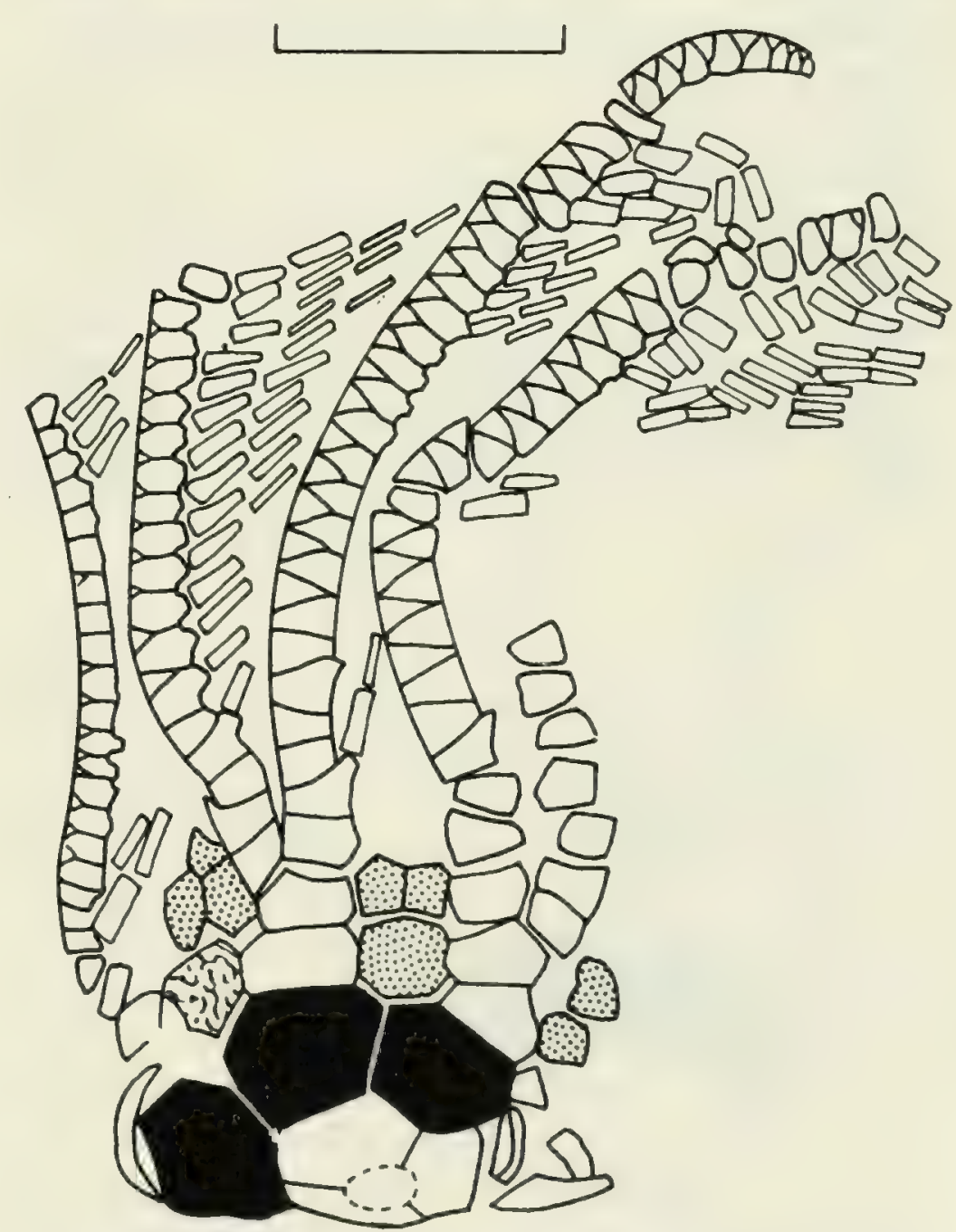

Text-fig. 7 Macrostylocrinus jordanensis sp. nov. Holotype centred on BC-interray, ROM 38997a, PI 10, fig. 6.

Radials black; primanal wrinkle stipple; anals and interbrachials dot stipple. Scale $5 \mathrm{~mm}$ 


\section{Order Diplobathrida Moore and Laudon, 1943 \\ Superfamily Dimerocrinatacea Zittel, 1879 \\ Family Dimerocrinitidae Bassler, 1938}

\section{Nexocrinus gen. nov.}

\section{TYPE SPECIES}

Nexocrinus delicatulus sp. nov.

\section{ETYMOLOGY}

From the Latin nexus - link - in reference to the inferred intermediate position of this genus in the evolution of the Dimerocrinitidae.

\section{DIAGNOSIS}

Genus of Dimerocrinitidae with small, cone-shaped aboral cup and inflated interrays. CD-interray slightly wider than others. Median ridges prominent on rays. Infrabasals small, concealed by stem. Posterior basal hexagonal, supporting primanal that separates posterior radials. Arms 20 , four per ray, uniserial, pinnulate.

\section{DISCUSSION}

Most genera currently assigned to the Dimerocrinitidae possess biserial arms. This includes the genera Ambicocri-

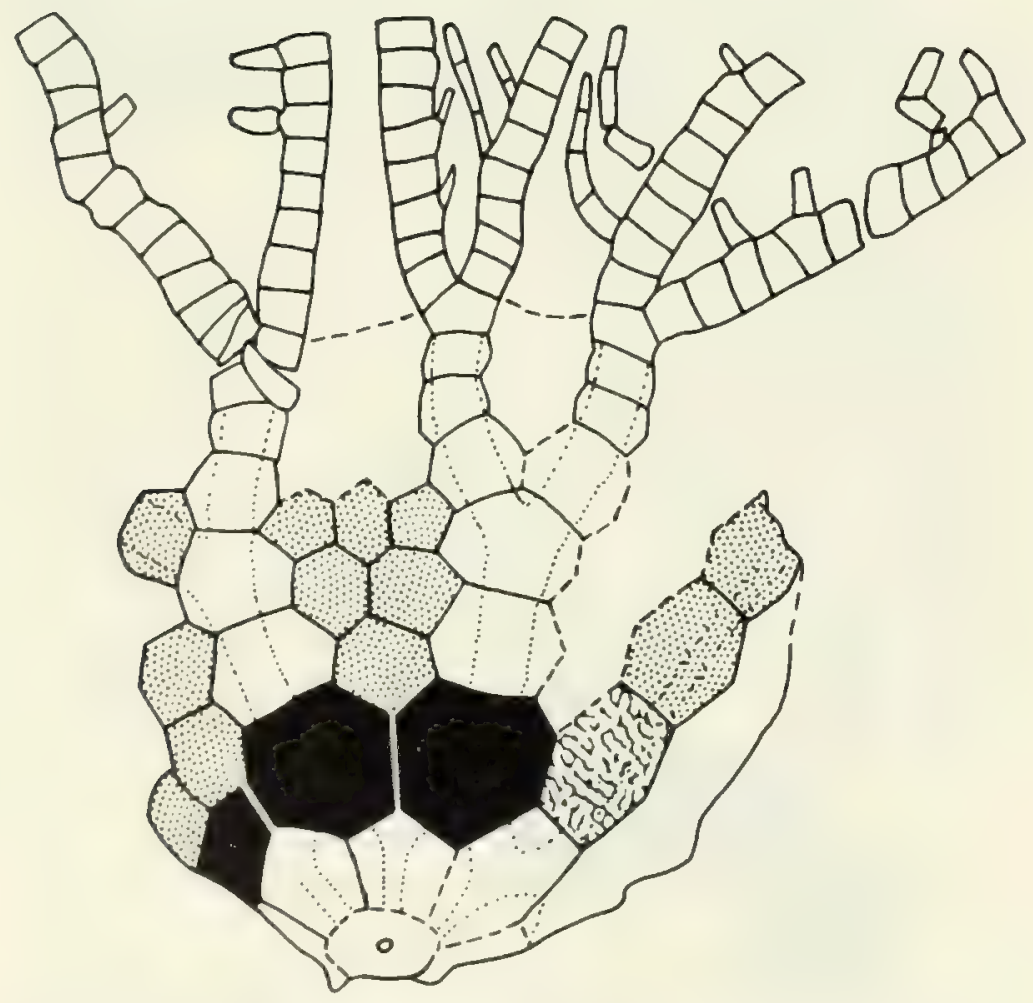

Text-fig. 8 Nexocrinus delicatulus gen. et sp. nov Holotype centred on DE-interray, ROM 666 1-A, PI. 3, fig. 4

Radials black; primanal wrinkle stipple; anals and interbrachials dot stipple. Scale $5 \mathrm{~mm}$. nus, Cyphocrinus, Dimerocrinites, Eudimerocrinus, and Griphocrinus. Macarocrinus, Pterinocrinus, and Ptychocrinus are dimerocrinitids characterized by uniserial arms. Macarocrinus has large, differentiated orals, in contrast to the incompetent tegmen of Nexocrinus gen. nov., and has a different arm structure. The arms of Pterinocrinus possess compound bipinnulated brachials in contrast to the simple, uniserial brachitaxis of Nexocrinus. Similarity with Ptychocrinus is much closer. Of the species at present assigned to Ptychocrinus, $P$. parvus (Hall), a species that should probably be removed from Ptychocrinus (see p. 20 for discussion), is allied most closely with $N$. delicatulus. $P$. parvus resembles Nexocrinus in that it possesses concealed infrabasals, narrow, median ray ridges, and 20 uniserial, unbranched arms. $P$. parvus, however, has two fixed secundibrachials, while Nexocrinus possesses four. The CD-interray of Nexocrinus is wider than that of $P$. parvus and has a distinct anal ridge. The primanal of the specimen of $P$. parvus figured by Hall (1872, pl. 5, fig. 17) supports a single series of three plates up to the level of the first axillaries, while the primanal of Nexocrinus supports an anitaxis that is flanked by smaller plates.

Nexocrinus appears to be monotypic, but a thorough study of the Dimerocrinitidae is needed to determine whether or not additional species of the genus Nexocrinus exist.

\section{Nexocrinus delicatulus sp. nov. \\ Text-fig. 8; Pl. 3, figs. 2-5}

\section{TYPE MATERIAL}

Only four specimens were sufficiently well preserved for study: holotype ROM 666cl-A; paratypes figured ROM 666cl-B, 39050, 39051 .

\section{OCCURRENCE}

Whirlpool Formation at Cataract and Credit Forks, Ontario; Cabot Head Formation, $2.3 \mathrm{~m}$ above base, at Ball's Falls on Twenty Mile Creek near Jordan, Ontario.

\section{ETYMOLOGY}

The specific name refers to the delicate, pinnulate arms of this species.

\section{DIAGNOSIS}

As for genus. 
Table 3 Measurements (in $\mathbf{m m}$ ) of type of Nexocrinus delicatulus gen. et sp. nov.

Holotype ROM 666cl-A

\begin{tabular}{llll}
\hline Aboral cup height & 6.8 & Axillary, height & 0.66 \\
Aboral cup width & $5.3^{*}$ & Axillary, width & 1.0 \\
Basal height & 0.80 & Anal X height & 1.3 \\
Basal width & 0.75 & Anal X width & 1.1 \\
Radial height & 1.1 & Anal $_{2}$ height & 1.2 \\
Radial width $_{\text {Primibrachial }_{1} \text { height }}$ & 1.5 & Anal $_{2}$ width & 0.96 \\
Primibrachial $_{1}$ width & 0.71 & Arm length & $6.6^{* *}$ \\
\end{tabular}

* Measurement approximate owing to distortion of specimen.

** Distal portions of arms not preserved.

\section{DESCRIPTION}

Height of crown approximately $30 \mathrm{~mm}$. Aboral cup small, cone-shaped, slightly higher than wide (Table 3 ). Interrays inflated. Posterior interray wider than others. Plates of ray series and basals bear prominent narrow $(0.5 \mathrm{~mm})$ median ridges that remain nearly constant in width throughout their length. Ridges bifurcate near the centre of each radial plate; branches diverge aborally and continue onto each of adjoining basals, forming depressed areas of equilateral triangular shape. Depressed areas bounded proximally by column, ventrolaterally by two ray-ridge segments shared between adjacent basals (Pl. 3, fig. 3). Ridges from two adjoining radials meet and coalesce near centre of each basal, forming angular, raised nodes just above column. Adorally, ray ridges remain as single straight segments from centre of each radial plate to each first axillary and bifurcate near centre of first axillary at angles of $50^{\circ}-60^{\circ}$ to produce gently curved ray segments that in turn bifurcate on fourth secundibrachial and merge with free brachials above. Posterior interray with distinct anal ridge. Plates without additional ornamentation. Infrabasals five, small, concealed by stem. Basals five, erect, pentagonal, with heights equal to widths-except posterior basal, which is larger, hexagonal, and elongate. Radials in lateral contact except at posterior side. Radials heptagonal, wider than high-except C- and D-ray radials, which are hexagonal. First primibrachial smaller, hexagonal, wider than high, followed by second primibrachial, which is heptagonal, with height equal to width. Secundibrachials four, pentagonal to heptagonal, becoming smaller distally. First interprimibrachial hexagonal, small, supporting two smaller plates that extend to level of adjoining axillaries; smaller plates followed by at least three ranges of smaller plates that merge into the tegmen. Primanal hexagonal, elongate; proximal half contained within radial circlet (Text-fig. 8; Pl. 3, fig. 4). Secundanal hexagonal, subequal, followed by at least one more plate to form an anitaxial ridge bordered by smaller, irregular plates. Free arms 20, four per ray, delicate, uniserial, pinnulate above first or second tertibrachial (Pl. 3, fig. 4). Some brachials cuneate. Pinnules rounded, long and slender; fixed pinnules do not appear to be present.

Column cylindrical, heteromorphic, tapering distally almost to a point. At least three orders of columnals present. Columnals three to seven per noditaxis, increasing in number distally. Nodals with extremely broad, downcurved epifacets up to one-half of columnal diameter in width (Pl. 3, fig. 5). Margins of proximal epifacets scalloped. Priminternodals bear smaller epifacets. Epifacets less prominent distally, restricted to nodals. Secundinternodals without epifacets. Crenularium broad, with numerous fine, nonbranching culminae. Lumen small, round.

\section{DISCUSSION}

Johnson (1934) believed Nexocrinus delicatulus gen. et sp. nov. to be an undescribed species of Alisocrinus. He obtained the "types"' from the upper part of the Whirlpool Formation in the Cataract-Credit Forks area west of Toronto.

Nexocrinus delicatulus is a small, thin-plated crinoid that was susceptible to recrystallization that obliterated plate sutures. Only the holotype and three paratypes were suitable for study. Numerous specimens collected from the Cabot Head Formation at Ball's Falls are badly recrystallized and are provisionally assigned to this genus.

The small size of the type specimens of $N$. delicatulus may indicate that these individuals are juveniles. The relatively wide spacing of the pinnules and the absence of intersecundibrachials in these specimens are characteristics typical of juvenile dimerocrinitids. 


\section{Genus Ptychocrinus Wachsmuth and Springer, 1885}

\section{TYPE SPECIES}

By designation of Wachsmuth and Springer, 1897:197; Gaurocrinus splendens S. A. Miller, 1883b.

\section{DIAGNOSIS}

A genus of Dimerocrinitidae with obconical, thinly plated cup, well-developed median ray ridges, depressed interprimibrachials, and distinct anal ridge. Arms 10 to 20, uniserial, simple or branching isotomously.

\section{KNOWN RANGE AND DISTRIBUTION}

Upper Ordovician to Lower Silurian, in North America and Europe.

\section{DISCUSSION}

Species currently assigned to Ptychocrinus include the Upper Ordovician forms $P$. splendens (Miller), $P$. fimbriatus (Schumard), and $P$. parvus (Hall), and the Lower Silurian species $P$. medinensis Brett and $P$. longibrachialis Brower. Brower (1973) noted that species assigned to Ptychocrinus are highly divergent. The writer is in agreement with this observation and believes that Ptychocrinus is in need of taxonomic revision. P. parvus, in particular, should be removed from Ptychocrinus since it possesses 20 arms while other Ptychocrinus species possess only 10 arms.

\section{Ptychocrinus medinensis Brett, 1978a}

Text-figs. 19, 20; Pl. 3, figs. 1, 7

Ptychocrinus medinensis Brett, 1978a:91-103, text-figs. 3-6; pl. 1, figs. 1-7; pl. 2, figs. 1-8.

\section{DIAGNOSIS}

A large species of Ptychocrinus with narrow median ridges on rays. Height of crown approximately $100 \mathrm{~mm}$. Infrabasals largely concealed by column. Plates with stellate ornamentation. Free arms branch isotomously a maximum of four times.

\section{DISCUSSION}

The original description (Brett, 1978a) stated that the arms of Ptychocrinus medinensis branched twice above the calyx. Well-preserved specimens recently discovered at Ball's Falls on Twenty Mile Creek near Jordan, Ontario, show that the arms bifurcate as many as four times above the calyx. The degree of arm branching increased through ontogeny. Juveniles typically display two or three branchings while the arms of large adults may bifurcate four times. Brett (1978a) observed bifurcations on the fourteenth to the seventeenth secundibrachial and again on the twenty-fifth to the twenty-eighth tertibrachial of this species. The more than 200 specimens collected from Ball's Falls, of which at least 80 are available for study, show considerably more variation in arm branching. Bifurcations occur on the tenth to the twenty-second secundibrachial, the twenty-first to the sixty-fifth tertibrachial, and again on the sixteenth to the thirty-fifth quartibrachial. A bifurcation on the first tertibrachial of one individual is considered abnormal (ROM 39079b).

Ptychocrinus medinensis is probably a direct descendant of the Upper Ordovician species $P$. splendens. The larger size of $P$. medinensis, the stellate ornamentation of its plates, and the concealed infrabasals, narrow ray ridges, and repeatedly branching arms on this species differentiate it from $P$. splendens.

The plates on the cup of Ptychocrinus medinensis are rather thin and easily destroyed during preparation of specimens. The characteristic stellate ornamentation is judged to be a feature that served to strengthen these ossicles. Median ridges on the rays also served to strengthen the cup. The aborally directed bifurcations of the median ridges near the base of the calyx formed a triangulated network that provided strength and rigidity. This arrangement is typical of many dimerocrinitids, reteocrinids, archaeocrinids, and other lower Palaeozoic camerates. The planar configuration of the infrabasal and the proximal portion of the basal circlet provided a large area for attachment of the stem, strengthening the union of stem and calyx and permitting development of a stout, long column (6 mm in diameter and $50-70 \mathrm{~cm}$ in length) that may have been of adaptive advantage (p. 44-46).

Ptychocrinus medinensis is judged to have been a moderate- to high-energy rheophile. The species was adapted to marginal environments and to a variety of substrates including carbonates and terrigenous clastics. It is the most common and most widely distributed crinoid of the Cataract Group.

\section{OCCURRENCE}

Power Glen Formation, 3-5 $\mathrm{m}$ above base, in the Niagara Gorge at $0.6 \mathrm{~km}$ south of Lewiston, New York (type locality); Cabot Head Formation, $0.9 \mathrm{~m}$ and $3.0 \mathrm{~m}$ above base, at Ball's Falls on Twenty Mile Creek near Jordan, Ontario. Columnals of this species occur in the lower part of the Cataract Group in Ontario and equivalent strata in the Medina Group of western New York State. 


\section{Subclass Inadunata Wachsmuth and Springer, 1885 \\ Order Disparida Moore and Laudon, 1943 \\ Superfamily Calceocrinacea Meek and Worthen, 1869 \\ Family Calceocrinidae Meek and Worthen, 1869}

\section{Genus Calceocrinus Hall, 1852}

\section{TYPE SPECIES}

By designation of Wachsmuth and Springer 1886:205; Cheirocrinus chrysalis Hall, 1860.

\section{DIAGNOSIS}

Genus of Calceocrinidae with bilaterally symmetrical crown and weakly developed main axil series. Basals four. E-ray inferradial and superradial generally in narrow contact. B- and C-ray inferradials present, separated adanally by subanal. A- and D-ray radials large, undivided, supporting axil series. Arms three; main axils relatively few and intercalated with nonaxillary plates, giving off unbranched ramules at intervals in typical

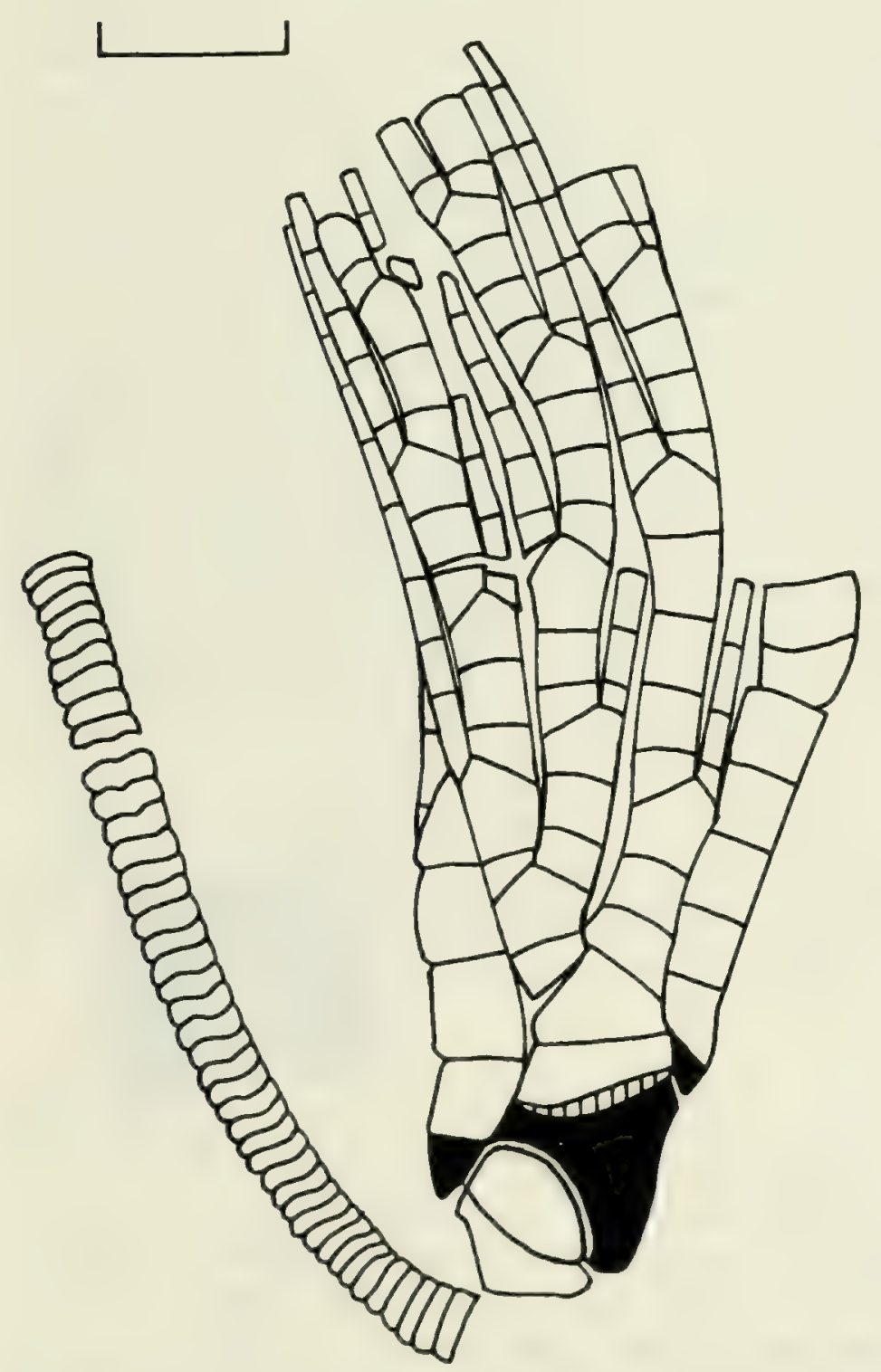

Text-fig. 9 Calceocrinus pustulosus Brower. A-ray view of holotype ROM $628 \mathrm{cl}$, PI. 4, fig. 12.

Radials black. Scale $5 \mathrm{~mm}$. calceocrinid pattern. Median (E-ray) arm generally branched dichotomously but may be unbranched.

\section{KNOWN RANGE AND DISTRIBUTION}

Middle Ordovician to Upper Silurian, in North America and Europe.

\section{Calceocrinus pustulosus Brower, 1966}

Text-fig. 9; Pl. 4, fig. 12

Calceocrinus pustulosus Brower, 1966:627-628, text-fig. 2c; pl. 75, fig. 13.

\section{DIAGNOSIS}

A species of Calceocrinus characterized by wide aboral cup, three main axils, strongly developed heterotomy of axil arms, and branched E-ray arm.

\section{DISCUSSION}

Calceocrinus pustulosus is known only from the holotype (ROM 628cl). The writer collected several calceocrinids at the type locality, but none appear to be conspecific with $C$. pustulosus.

\section{OCCURRENCE}

Manitoulin Formation at Devil's Punch Bowl near Stoney Creek, Ontario.

\section{Calceocrinus tridactylus sp. nov.}

Text-fig. 10A-C; Pl. 4, figs. 5-9

\section{TYPE MATERIAL}

Three specimens were available for study: holotype ROM 39007, paratype figured ROM 39008, paratype unfigured ROM 39009.

\section{OCCURRENCE}

Cabot Head Formation, $1.3 \mathrm{~m}$ above base, at Ball's Falls on Twenty Mile Creek near Jordan, Ontario.

\section{ETYMOLOGY}

From the Latin tri-three, and dactylus-finger-in reference to the three main arms of this calceocrinid.

\section{DIAGNOSIS}

A species of Calceocrinus characterized by a wide aboral cup, four robust, extensively branched axil arms, and a 
repeatedly branched E-ray arm. Branching of axil arms strongly heterotomous proximally, becoming nearly isotomous distally.

\section{DESCRIPTION}

Height of crown approximately $32 \mathrm{~mm}$. Calyx rectangular in anterior (E-ray) view; width one-half of height. Ornamentation variable; distal portions of arms faintly pitted; pitting becomes more prominent proximally. Patterns of pitting coalesce and form narrow, irregular ridges on calyx (Pl. 4, fig. 9). Basal circlet triangular, with height about equal to width, enclosed within triangular notch formed by B- and C-ray inferradials and subanal. Basals four, all forming part of column facet. Basal sutures well defined; centrally located DE- and EA-interray basals separated by straight median suture; sutures with lateral (AB- and CD-interray) basals sinuous (Pl. 4, fig. 6). Median (E-ray) inferradial and superradial in narrow contact. Inferradial with width about one-half of height (Table 4), tapering distally, with slightly concave lateral sutures. E-ray superradial triangular, with height one-half of width, and with well-developed distal articulat- ing facet (Text-fig. 10C; Pl. 4, fig. 9). A- and D-ray radials largest aboral-cup plates; posterolateral corners deeply notched for B- and C-ray inferradials. Radial facets broad and steeply sloping. B- and C-ray inferradials tumid, roughly elliptical with pointed abanal and adanal extremities (Text-fig. 10A; Pl. 4, fig. 7). Subanal plate anvil-shaped, widening adorally. Anal tube incompletely preserved in type material, composed of stout quadrangular plates; height and width of plates equal. Arms three, robust, and extensively branched. First primibrachial of E-ray wider than high, tapering distally. Brachials massive proximally, wider than high, becoming more slender distally. E-ray arm bifurcates on fourth or fifth primibrachial, fourth secundibrachial, fourth tertibrachial, and sixth quartibrachial (Text-fig. 10B; Pl. 4, fig. 5). First bifurcation isotomous; higher bifurcations heterotomous. Lateral arms symmetrical, extensively branched. Main axil series typically composed of eight plates (nine in D-ray of holotype), four of which are axillary. First plate of axil series nonaxillary, broad, low, tapering distally. Axillaries of shape of equilateral triangle, with subequal, concave distal facets. Third, fifth, and seventh axils

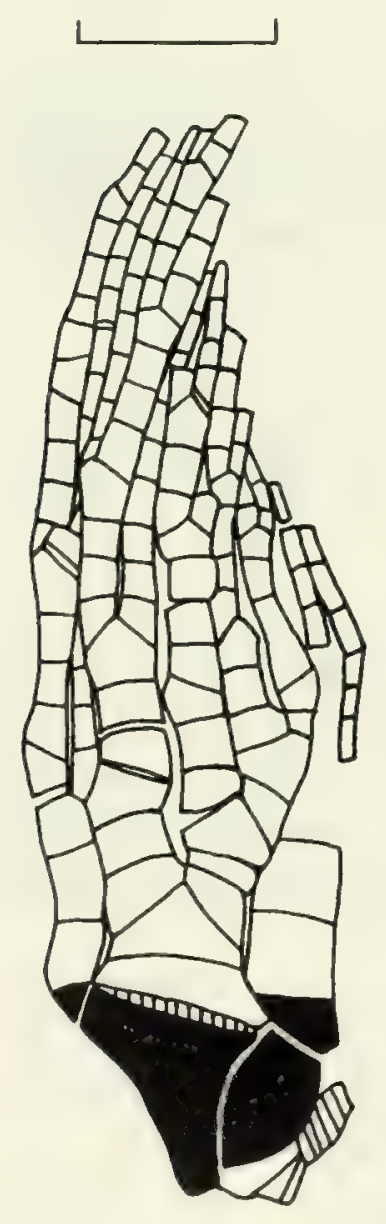

A

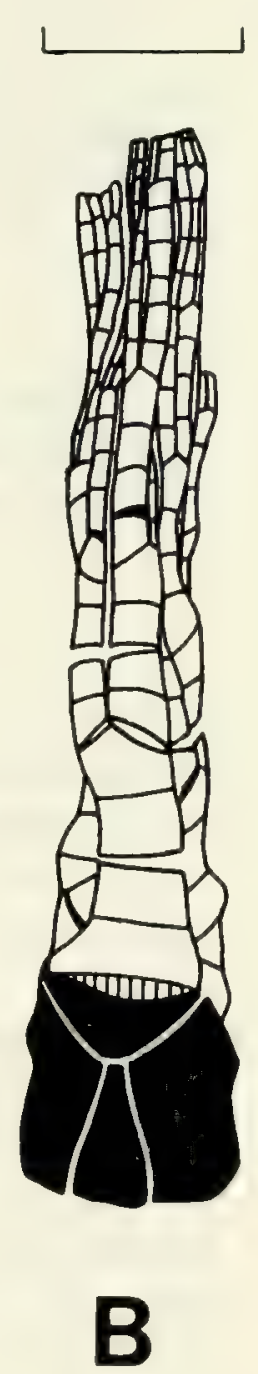

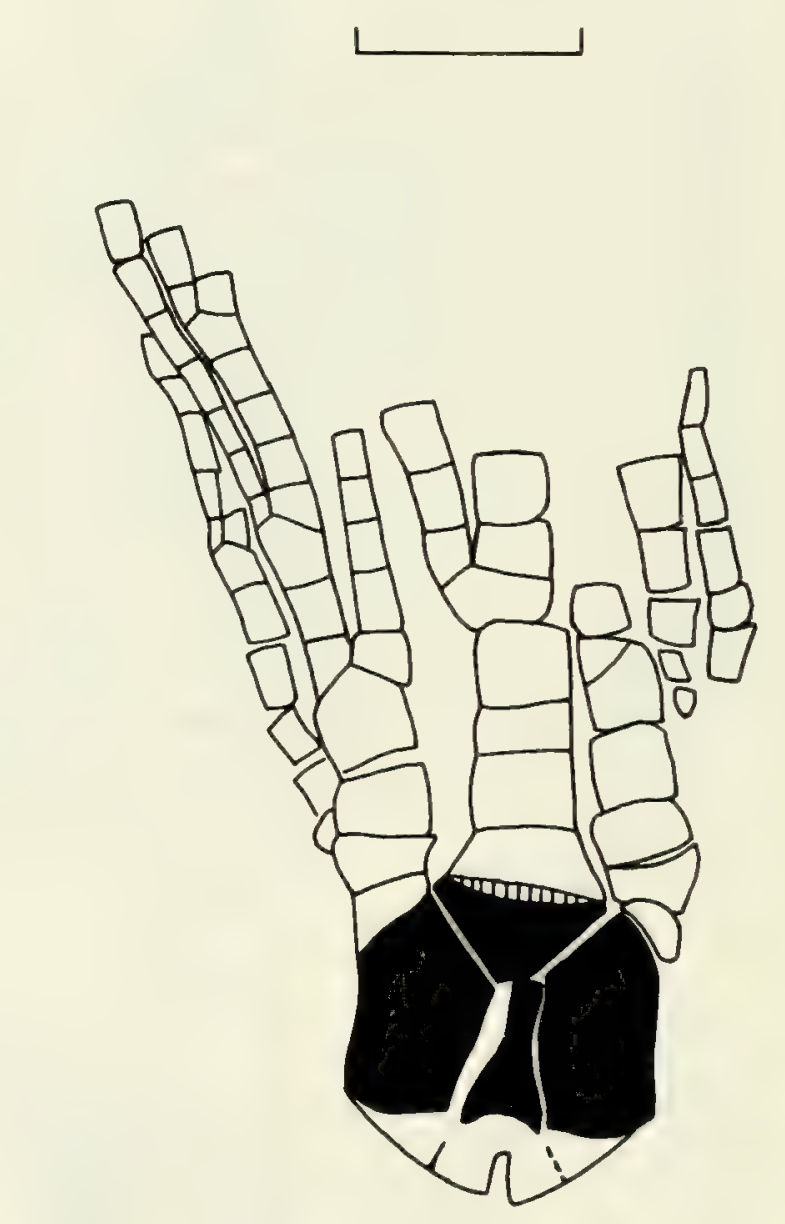

C

Text-fig. 10A-C Calceocrinus tridactylus sp. nov. Radials black. Scales $5 \mathrm{~mm}$.

A D-ray view of holotype ROM 39007, Pl. 4, fig. 7.

B E-ray view of holotype ROM 39007, PI. 4, fig. 5.

C Individual centred on E-ray of paratype ROM 39008, Pl. 4, fig. 9. 
Table 4 Measurements (in $\mathrm{mm}$ ) of types of Calceocrinus tridactylus sp nov.

\begin{tabular}{lcc} 
Measurements & $\begin{array}{c}\text { Holotype } \\
\text { ROM 39007 }\end{array}$ & $\begin{array}{c}\text { Paratype } \\
\text { ROM 39008 }\end{array}$ \\
\hline Crown height & $32.0^{*}$ & $24.0^{*}$ \\
A-ray radial height & 6.1 & 4.8 \\
B-ray radial height & 4.1 & - \\
B-ray radial width & 2.8 & - \\
E-ray inferradial height & 4.1 & 3.1 \\
E-ray inferradial width & 2.2 & 1.8 \\
E-ray superradial height & 2.3 & 1.8 \\
E-ray superradial width & 4.3 & 3.3 \\
Subanal height & 1.2 & - \\
Subanal width & 3.5 & - \\
Anal X height & 2.3 & - \\
Anal X width & 3.4 & \\
\end{tabular}

* Distal portions of arms not preserved.

nonaxillary, smaller than axillaries, trapezoidal in form, and tapering abanally. Axil arms abut closely proximally. Primaxil arm bifurcates on third (or on rare occasion second) alphabrachial, third betabrachial, third or fourth gammabrachial, fourth deltabrachial, and fourth epsilonbrachial. Secundaxil arm bifurcates on third alphabrachial, fourth betabrachial, and third gammabrachial; distal portions not preserved. Tertaxil arm bifurcates on third alphabrachial, third or fourth betabrachial, and third or fourth gammabrachial; distal portions not preserved. Quartaxil arm bifurcates on fourth alphabrachial; distal portions not preserved. Four brachials of omega ramule preserved in D-ray of holotype. Proximal bifurcations of arms strongly heterotomous; distal branchings nearly isotomous (see Text-fig. 10A and Pl. 4, figs. 7, 8 for patterns of arm branching). Axillaries of arms slightly nodose

Proximal portion of column known in one individual. Column round; proxistele composed of low columnals. Mesistele homoeomorphic; columnals approximately three times wider than high. Dististele and holdfast unknown.

\section{DISCUSSION}

Calceocrinus tridactylus sp. nov. is an uncommon species. The type specimens were found with an occurrence of Macrostylocrinus jordanensis. The bestpreserved specimen has been selected as the holotype. It is slightly abnormal in that it has an extra plate in the axil series of the D-ray between the primaxil and secundaxil arms.

Calceocrinus tridactylus may be distinguished from $C$. pustulosus Brower by its four rather than three axil arms, its tapering rather than rectangular E-ray inferradial, and its stronger and more rugose ornamentation. All four basals share the stem facet in $C$. tridactylus; only the ABand $\mathrm{CD}$-interray basals share this facet in $C$. pustulosus. The columnals of $C$. tridactylus lack the sinuous sutures present in $C$. pustulosus.

The ancestry of Calceocrinus tridactylus is uncertain. This species is not closely related to $C$. pustulosus and may have been derived from a Middle or Upper Ordovician species. However, few Ordovician species of Calceocrinus are known at present, and none resemble the new species. $C$. tridactylus does not appear to be an ancestor of any currently known Silurian species.

\section{Diaphorocrinus gen. nov.}

\section{TYPE SPECIES}

Diaphorocrinus pleniramulus sp. nov.

\section{ETYMOLOGY}

From the Greek diaphoros — different-in reference to the arm-branching pattern that differentiates this genus from other calceocrinids, and from the Greek krinon-lily.

\section{DIAGNOSIS}

Monotypic genus of Calceocrinidae with well-developed bilateral symmetry. Basal circlet composed of three plates. E-ray inferradial in contact with superradial. Main axil series well developed, consisting of successive axillaries interposed with nonaxillary plates. Arms three, robust, extensively branched. A- and D-rays each with five axil arms that abut closely; each bifurcation of an axil arm gives off two branches that typically divide again. Typical calceocrinid pattern of unbranched ramules not evident.

\section{DISCUSSION}

The axil-arm structure of Diaphorocrinus differentiates this genus from the majority of calceocrinids, which are characterized by unbranched ramules arranged as follows: "The pattern of branching is remarkably constant, alpha-ramules being given off invariably on the abanal side of the arm, beta-ramules on the adanal side, and so on' (Moore, 1962:36). In Diaphorocrinus, however, each bifurcation of axil arms bears two branches that typically divide again.

The numerous bifurcations of the axil arms of Diaphorocrinus greatly increase the total length of the ambulacral tract. The structure of the lateral axil arms of $D$. pleniramulus sp. nov, is incompletely known at present, but its ambulacral tract is probably an order of magnitude greater in length than that of most calceocrinids. This atypical structure of the axil arms of 
Diaphorocrinus is repeated on two unrelated calceocrinid specimens within the same narrow stratigraphic interval. One individual appears to be an aberrant specimen of Calceocrinus (ROM 39066a, Pl. 4, fig. 10). The remaining specimen, to be described in a future publication, was found associated with an occurrence of Ptychocrinus at Ball's Falls. Bifurcations of ramules also occur on the Ordovician calceocrinid Cremacrinus gerki (Brower and Strimple, 1983). The similar structure of the axil arms of these unrelated genera is hypothesized to have resulted from a selective pressure that favoured convergent evolution. The bifurcation of typically unbranched ramules may have evolved in response to competition for trophic resources. Alternatively, it may represent an adaptation for the capture of small food particles.

Calceocrinids increased the total length of their foodgathering systems through a variety of evolutionary mechanisms, including an increase in the number of axil arms, from two or three in Cremacrinus to five or eight in Anulocrinus, Chirocrinus, Synchirocrinus, Chiropinna, and Halysiocrinus (Moore, 1962). Repeated bifurcations of the E-ray arm also increased ambulacral-tract length. Primitive Ordovician species such as Calceocrinus longifrons (Brower, 1977:24, pl. 4, figs. 1-8) tend to have unbranched E-ray arms, whereas advanced forms such as the Mississippian species Halysiocrinus nodosus (Springer, 1926:232, pl. 30, figs. 1-8) typically have extensively branched arms. Certain species, including Deltacrinus clarus (Moore, 1962:17, pl. 1, fig. 7), have rather long arms that may also have aided feeding. Large numbers of ramules also increased the length of the ambulacral tract of the Ordovician calceocrinid Calceocrinus multibifurcatus and the Upper Silurian species Cremacrinus tubuliferus (Springer, 1926:228, pl. 28, figs. 3-6). Chiropinna represents an extreme example where ramules proliferated to such an extent that the axil arms became pinnulate (Moore, 1962:16, pl. 2, figs. 2a-c). Finally, Diaphorocrinus adopted the unusual strategy of repeated divisions of ramules unbranched on other calceocrinids.

The proximal bifurcations of the axil arms of Diaphorocrinus are largely concealed between the lateral rays. The distal bifurcations, however, remain in view. In contrast, the unbranched beta ramules of Synchirocrinus conceal higher bifurcations of the axil arms.

The evolutionary lineage that leads to Diaphorocrinus is unknown. This genus is a divergent, specialized form that is not closely related to other calceocrinids. The presence of four arm-bearing rays in Cremacrinus and Anulocrinus renders derivation from these genera unlikely. Paracremacrinus is also an unlikely ancestor. Intercalated nonaxillary plates in the axil series of Diaphorocrinus suggest that it could not have descended from Chirocrinus or Synchirocrinus. At present, derivation from Calceocri- nus through the bifurcation of ramules and the fusion of basals appears plausible.

\section{Diaphorocrinus pleniramulus sp. nov. Text-fig. 11A-D; Pl. 4, figs. 1-4}

\section{TYPE MATERIAL}

Three specimens were available for study: holotype ROM $39010 a$, paratypes figured ROM 39010b, c.

\section{OCCURRENCE}

Cabot Head Formation at Devil's Punch Bowl near Stoney Creek, Ontario.

\section{ETYMOLOGY}

From the Latin plenus-full, and ramulus-small branch-in reference to the numerous ramules of the axil arms of this species.

\section{DIAGNOSIS}

As for genus.

\section{DESCRIPTION}

Height of crown approaches $30 \mathrm{~mm}$. Bilateral symmetry well developed. Plates ornamented with numerous small pits that coalesce to form irregular ridges (Pl. 4, figs. 3, 4). Basal circlet subtriangular, wider than high, composed of three plates (Text-fig. 11C). Basal sutures faint. DEand EA-interray basals fused to form single median plate of full width of basal circlet. AB-and CD-interray basals triangular, sharing column facet. Basal circlet closely abutting B- and C-inferradials and partly enclosed by them

Table 5 Measurements (in $\mathbf{m m}$ ) of types of Diaphorocrinus pleniramulus gen. et sp. nov.

\begin{tabular}{lcc} 
Measurements & $\begin{array}{c}\text { Holotype } \\
\text { ROM 39010a }\end{array}$ & $\begin{array}{c}\text { Paratype } \\
\text { ROM 39010c }\end{array}$ \\
\cline { 2 - 3 } Crown height & 29.0 & - \\
A-ray radial height & - & 3.2 \\
B-ray radial height & $2.8^{*}$ & - \\
D-ray radial height & $4.8^{*}$ & - \\
E-ray inferradial height & - & 1.9 \\
E-ray inferradial width & - & 1.6 \\
E-ray superradial height & 1.3 & 1.3 \\
E-ray superradial width & - & 2.9 \\
Proximal stem diameter & 1.7 & - \\
\end{tabular}

* Measurement approximate owing to breakage of these ossicles 
when hinge in closed position. E-ray inferradial and superradial in narrow contact (Text-fig. 11D; PI. 4, fig. 4). Inferradial triangular, expanded and forked proximally, with concave sides that become parallel distally. Superradial subtriangular; height one-half of width (Table 5). A- and D-ray radials largest plates in calyx; posterolateral sides concave for reception of B- and C-ray inferradials. Radial facets declivate, broad, straight, with upturned, adorally directed spear-shaped projections. Band C-ray inferradials tumid, strongly rounded. Presence or absence of subanal not determined. Proximal portion of anal tube preserved, consisting of stout quadrangular plates; height of each plate one-half of width (Text-fig. 11B; Pl. 4, fig. 4). Arms three; E-ray arm very stout, bifurcating four times, composed of broad quadrangular brachials. First bifurcation isotomous on fourth primibrachial; higher heterotomous bifurcations present on third secundibrachial and fourth tertibrachial (Text-fig. 11 A; Pl. 4, fig. 1). Distal faces of all axillaries have well-developed articulating facets that create a gaping appearance when
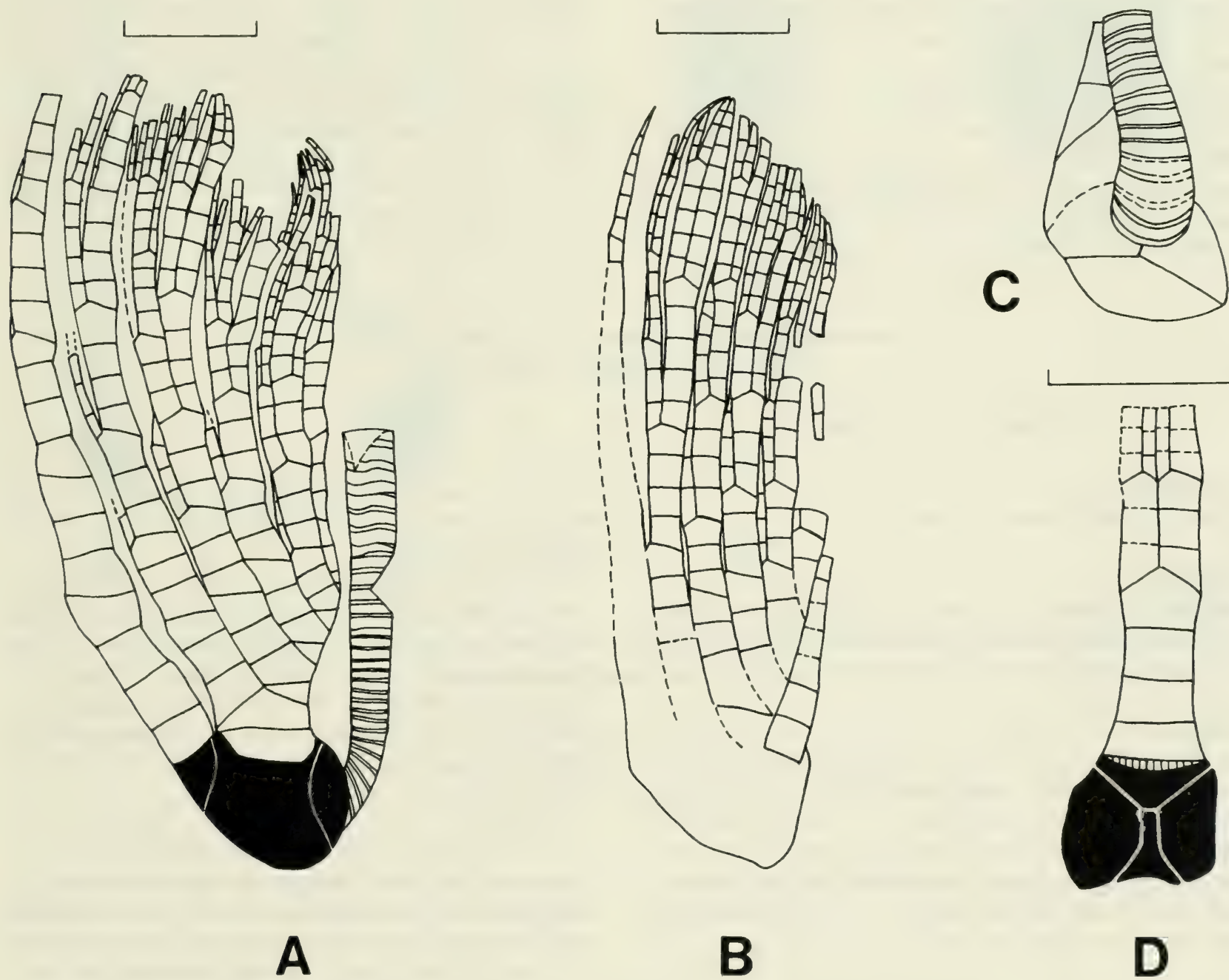

Text-fig. 11A-D Diaphorocrinus pleniramulus gen. et sp. nov.

Radials black. Scales $5 \mathrm{~mm}$.

A D-ray view of holotype. Each bifurcation of an axil arm gives off two branches that each divide again. This repeated branching of axil arms differentiates Diaphorocrinus from most calceocrinids. ROM 39010a, Pl. 4, fig. 1

B D-ray view. Arms of this individual are tightly closed in a defensive posture, concealing much of their structure. Paratype ROM 39010b, Pl. 4, fig. 2.

C Posterior view of holotype ROM 39010a.

D E-ray view of paratype ROM 39010 c, Pl. 4, fig. 4. 
arms are in closed position. Main axil series prominent, consisting of successive axillaries interposed with single nonaxillary plates of equal size (Text-fig. 11A). First plate of axil series nonaxillary, broad, and low; succeeding nonaxillaries wedge-shaped. Axillaries broadly pentagonal with subequal distal sides. A- and D-rays each have five robust axil arms that abut closely adorally and conceal proximal branchings, as in Synchirocrinus. Axil arms bifurcate five or six times. Proximal bifurcations strongly heterotomous; distal branchings nearly isotomous (Textfig. 11B; Pl. 4, fig. 2). Each bifurcation produces two branches, which each bifurcate again (Text-fig. 11A). Some distal ramules do not branch (Text-fig. 11B). Typical calceocrinid pattern of unbranched alpha ramules, beta ramules, and so on is not evident in this species. Primaxil and secundaxil arms each have three primibrachials; tertaxil through quintaxil arms each have two primibrachials. Bifurcations occur on following plates: third secundibrachial, third tertibrachial, third or fourth quartibrachial, and fourth to eighth quintibrachials (Textfig. $11 \mathrm{~A}, \mathrm{~B}$; Pl. 4, figs. 1, 2). Distal widths of axillaries greater than proximal widths, giving nodose appearance to arms. Proximal brachials subequal; distal brachials elongate.

Column round, smooth, incompletely known. Proxistele heteromorphic, composed of alternating thick and thin columnals of equal diameter (Pl. 4, fig. 1). Columnals lowest near basal circlet. Height of columnals one-eighth to one-fifth of width. Mesistele cryptohomoeomorphic.

\section{DISCUSSION}

The three known specimens of Diaphorocrinus pleniramulus gen. et sp. nov. are preserved on a small, lenticular slab of sandstone that contains shale-pebble intraclasts. The slab was found loose in the stream bed near the base of the upper falls at Devil's Punch Bowl near Stoney Creek, by Dr. Carlton E. Brett. The bases of the calyces of the holotype and of one paratype are partly broken away. Additional specimens have not been discovered despite careful investigation. Although the precise horizon is indeterminate, the slab was probably derived from the upper half of the Cabot Head Formation. The occurrence is thus stratigraphically higher than that of other calceocrinids from this locality.

\section{Superfamily Myelodactylacea S. A. Miller, 1883a Family Eustenocrinidae Ulrich, 1925}

\section{Cataractocrinus gen. nov.}

\section{TYPE SPECIES}

Cataractocrinus clementi sp. nov.

\section{ETYMOLOGY}

This genus is named in reference to the occurrence of the type species near the base of the lower falls at Ball's Falls on Twenty Mile Creek near Jordan, Ontario.

\section{DIAGNOSIS}

Monotypic genus of Eustenocrinidae with small, cylindrical aboral cup. Five basals appear to be present, each pentagonal and with height equal to width. Compound radials present in each ray. Anal $\mathrm{X}$ not incorporated into cup, supporting single armlike series of plates that become successively more elongate distally. Arms four, uniserial, apinnulate, branching isotomously.

\section{DISCUSSION}

Cataractocrinus gen. nov. is tentatively placed in the Eustenocrinidae, extending the range of this family into the Llandoverian. Cataractocrinus was probably derived from the Middle Ordovician genus Eustenocrinus when fixed brachials were expelled from the cup. Cataractocrinus resembles Peniculocrinus Moore to a lesser degree. Peniculocrinus has five arms and an anibrachial that supports an anal appendage whereas Cataractocrinus has only four arms, with the C-ray superradial directly supporting the anal sac.

Although the number of basals is at present indeterminate, the unique features of Cataractocrinus serve to firmly define this genus. The five compound radials, the four arms, and an anal appendage that is little differentiated from the arms are all features judged to be primitive. Similar features are more characteristic of certain Ordovician genera such as Eustenocrinus than of typical Silurian crinoids.

Interpretation of the plate structure of Cataractocrinus is difficult because of the undifferentiated nature of the cup plates. The C-ray is indistinguishable in the absence of the armlike anal structure, which in life probably formed the "backbone" of a delicate anal sac, as on calceocrinids. Anal X very closely resembles adjacent brachials. This feature is of interest from an evolutionary point of view: it has been postulated that the crinozoan anal structure may have been derived through evolutionary modification of the C-ray arm, implying that the first anal plate of these crinoids must have originated as a plate morphologically equivalent to an ordinary brachial (Ubaghs, 1978). This may well be the case for Cataractocrinus; the presence of four arms and the similarity of 


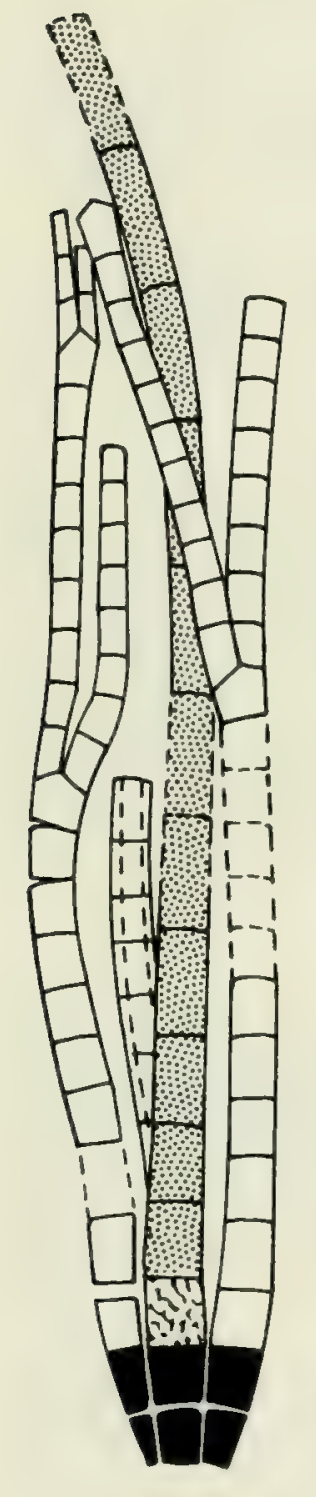

A

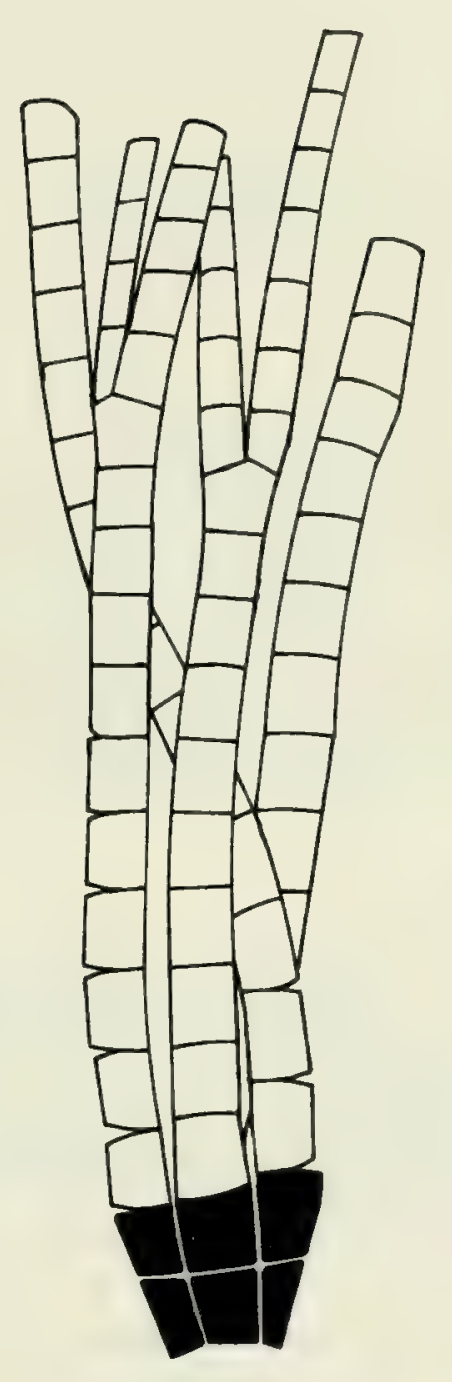

B
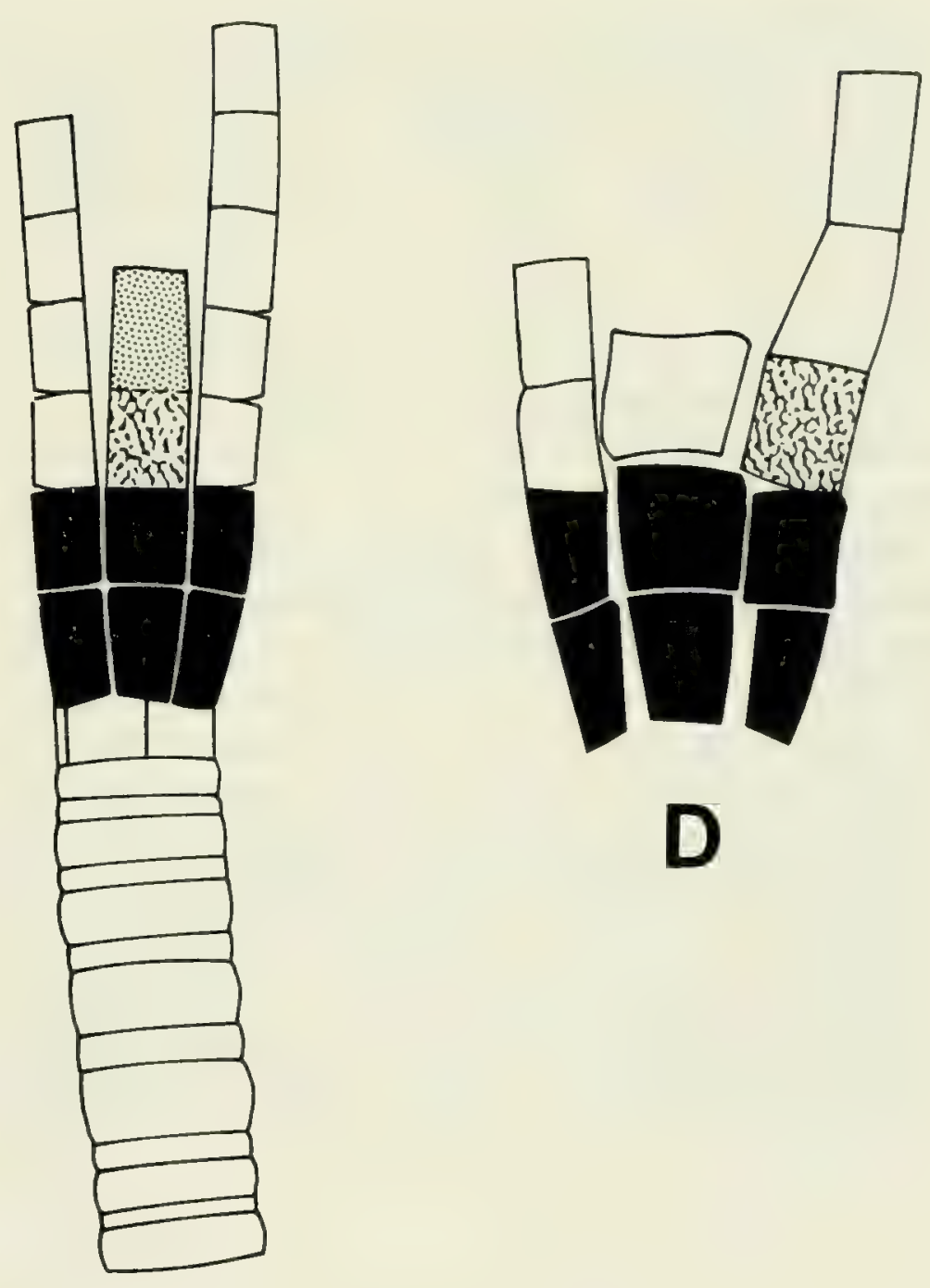

D

Text-fig. 12A-D Cataractocrinus clementi gen. et sp. nov.

Inferradials and superradials black; anal X wrinkle stipple; higher anals dot stipple; A, B scales 5 mm; C, D scales $1 \mathrm{~mm}$.

A Holotype centred on C-ray. Note long anal appendage and isotomous branching of arms, incomplete in this individual. Basals of this specimen are missing. ROM 39011, Pl. 5, fig. 1.

B Anterior view of typical individual. Basals of this specimen are missing. Paratype ROM 39012, PI. 5, fig. 2.

C Anterior view of only individual found attached to its column. Paratype ROM 39017, Pl. 5, fig. 9.

D Anterior view of crushed specimen. Basals are missing. Paratype ROM 39016, PI. 5, fig. 7.

the anal structure to the adjacent arms on this genus support the hypothesis. Differentiation of the first anal plate, however, had already occurred in unrelated genera by the Middle Ordovician.

\section{Cataractocrinus clementi sp. nov.}

Text-fig. 12A-D; PI. 5, figs. 1-9

\section{TYPE MATERIAL}

Ten specimens were available for study: holotype ROM 39011; paratypes figured ROM 39012 to 39014 inclusive,
ROM 39016 to 30919 inclusive; paratypes unfigured ROM 39015, 39048.

\section{OCCURRENCE}

Cabot Head Formation, $6.4 \mathrm{~m}$ above base, at Ball's Falls on Twenty Mile Creek near Jordan, Ontario.

\section{ETYMOLOGY}

The specific name refers to the discovery of this species by Mr. Craig Clement, a graduate student at the University of Tennessee at Knoxville. He found the specimens in difficult collecting conditions near the base of Ball's Falls. 
DIAGNOSIS

As for genus.

\section{DESCRIPTION}

Height of incomplete crown approximately $25 \mathrm{~mm}$. Cup small, cylindrical, flaring slightly above level of basals; diameter nearly that of stem (Pl. 5, fig. 8). Number of basals indeterminate, probably five. Basal circlet composed of subequal pentagonal plates forming a cylindrical ring; diameter equal to that of stem; sutures with stem indistinct (Pl. 5, fig. 9). Aboral cup displays perfect pentaradiate symmetry. All cup plates above basals arranged in horizontal and vertical rows, forming a checkerboard pattern. Plates smooth, unornamented. Compound radials present in all five rays. Inferradials quadrangular, flaring distally, subequal to slightly elongate (Table 6). Superradials smaller. Radial facets plenary, planate. Anal X on C-ray not incorporated into cup, undifferentiated, resembling a proximal brachial; height equal to width. Anal X supports long, unbranched, armlike anal appendage composed of single vertical series of plates that become successively more elongate distally (Text-fig. 12; Pl. 5, fig. 1). Proximal anal plates slightly higher than wide; distal plates approximately four times higher than wide. Anal plates thin, arcuate in cross section, with concave ventral surfaces. Arms four, uniserial, apinnulate, branching isotomously on the ninth to the eleventh primibrachial and again on the sixth to the eighth secundibrachial. Distal portions of arms not preserved. Brachials rounded aborally; shallow, wide groove present ventrally (Pl. 5, fig. 6). Heights of proximal brachials equal to widths; distal brachials elongate. First primibrachial may taper slightly (PI. 5, figs. 6, 7). Sutures between brachials depressed.

Stem length in incomplete specimens exceeds $15 \mathrm{~cm}$. Column round proximally, pentagonal distally. Proxistele heteromorphic, composed of alternating thick and thin columnals of equal diameter. Heights of columnals one-quarter to one-half of their widths. Mesistele round, homoeomorphic, grading into pentagonal dististele. Columnals of dististele composed of five distinct pentameres, each with a small, circular canal. Lumen small, concavopentastellate. Columnal sutures symplexial. Holdfast composed of numerous unbranched or sparsely branched radicles up to $3 \mathrm{~cm}$ in length arranged in loose whorls round distal $1.5-2 \mathrm{~cm}$ of column.

\section{DISCUSSION}

The delicate crown of Cataractocrinus clementi gen. et sp. nov. was susceptible to disarticulation upon the death of the organism and was rarely preserved intact. However, widespread occurrence of distinctive columnals in the Cabot Head Formation indicates that $C$. clementi was a common species.

Table 6 Measurements (in mm) of types of Cataractocrinus clementi gen. et sp. nov.

\begin{tabular}{|c|c|c|c|c|}
\hline Measurements & $\begin{array}{c}\text { Holotype } \\
\text { ROM } 39011\end{array}$ & $\begin{array}{c}\text { Paratype } \\
\text { ROM } 39012\end{array}$ & $\begin{array}{c}\text { Paratype } \\
\text { ROM } 39013\end{array}$ & $\begin{array}{c}\text { Paratype } \\
\text { ROM } 39014\end{array}$ \\
\hline Aboral cup height & $1.9^{*}$ & $1.5^{*}$ & $1.6^{*}$ & $1.7 *$ \\
\hline Aboral cup width & $2.4^{* *}$ & $2.3 * *$ & $1.8 * *$ & $2.4 * *$ \\
\hline Inferradial height & 0.86 & 0.79 & 0.79 & 0.93 \\
\hline Inferradial width & 0.64 & 0.91 & 0.82 & 0.89 \\
\hline Superradial height & 0.86 & 0.85 & 0.92 & 0.94 \\
\hline Superradial width & 0.91 & 0.96 & 0.81 & 0.93 \\
\hline Primibrachial $_{1}$ height & 0.89 & 0.95 & 0.88 & 1.1 \\
\hline Primibrachial, width & 0.81 & 0.86 & 0.83 & 0.94 \\
\hline Anal X height & 0.95 & - & - & - \\
\hline Anal $\mathrm{X}$ width & 0.91 & - & - & - \\
\hline $\mathrm{Anal}_{2}$ height & 0.97 & - & - & - \\
\hline Anal $_{2}$ width & 0.94 & - & - & - \\
\hline Arm length & $21.0 \dagger$ & $14.0 \dagger$ & $19.0^{\dagger}$ & $17.0^{\dagger}$ \\
\hline
\end{tabular}

* The basals of this specimen are missing.

** Measurement approximate owing to distortion of specimen.

† Distal portions of arms not preserved. 
Pariocrinus gen. nov.

\section{TYPE SPECIES}

Pariocrinus heterodactylus sp. nov.

\section{ETYMOLOGY}

Pariocrinus, in reference to the close affinity of this genus to Iocrinus .

\section{DIAGNOSIS}

Monotypic genus of Iocrinidae with small, steeply conical aboral cup. Cup structure resembles that of Iocrinus. C-ray anibrachial supports long armlike anal appendage to left and arm to right. Anal appendage composed of single series of plates that are successively more elongate distally. Arms five, apinnulate, bifurcating several times. First branching isotomous; higher branchings heterotomous.

\section{DISCUSSION}

Pariocrinus gen. nov. is closely related to Iocrinus, a Middle to Upper Ordovician genus endemic to North America and Europe. Pariocrinus is differentiated from Iocrinus by the heterotomous, rather than isotomous, bifurcations of its arms. Pariocrinus has straight or nearly straight radial facets, rather than the arcuate facets of locrinus, and has proportionately larger basals, narrower brachials, and a different anal structure and stem. The absence of interbrachials distinguishes Pariocrinus from Caleidocrinus, the third member of the Iocrinidae.

The plate here designated as an anibrachial occupies a position intermediate between that of the C-ray superradial of Ordovician inadunates such as Dystactocrinus and Isotomocrinus (incorporated into the cup) and that of the anibrachial of Iocrinus (not incorporated into the cup). The proximal edge of the corresponding plate on Pariocrinus is slightly below the level of adjoining radial facets, but the distal facets of this plate extend well beyond the level of the radials. For this reason, the plate on Pariocrinus is designated as an anibrachial rather than a superradial or aniradial (see Ubaghs, 1978:116 for discussion).

The heterotomous bifurcations of the arms of Pariocrinus may indicate evolutionary advancement overlocrinus. The pattern of arm heterotomy present in the new genus remains uncertain in the absence of specimens with complete arms. The strong heterotomy indicated suggests the possibility of unbranched ramules, arrayed either in an endotomous manner, as in Daedelocrinus, or in a bilateral heterotomous manner, as in most calceocrinids.

Pariocrinus was probably derived from an Ordovician species of locrinus. The discovery of Pariocrinus extends the range of iocrinids into the Llandoverian. No other Silurian or later forms are known that incorporate features possibly derived from Pariocrinus. This genus is interpreted to be an offshoot of the family that left no descendants.

\section{Pariocrinus heterodactylus sp. nov. Text-fig. 13A-D; PI. 6, figs. 1-6}

\section{TYPE MATERIAL}

Eleven specimens were available for study: holotype ROM 39026; paratypes figured ROM 39027, 39028, 39029a, 39030 ; paratypes unfigured ROM 39031 to 39036 inclusive.

\section{OCCURRENCE}

Cabot Head Formation, $3 \mathrm{~m}$ above base, at Ball's Falls on Twenty Mile Creek near Jordan, Ontario.

\section{ETYMOLOGY}

The specific name refers to the heterotomy of the arms of this species.

\section{DIAGNOSIS}

As for genus.

\section{DESCRIPTION}

Height of crown approximately $15 \mathrm{~mm}$. Aboral cup small, narrow, steeply conical. Plates smooth, unornamented Basals five, pentagonal, with heights equal to widths, gently curved in side view. Height of basal circlet one-half that of cup. Radials approximately same size as basals. Radials in contact all round, five-sided; heights equal to widths (Table 7) except on C-ray radial facet, which is smaller and wider than high. Radial facets plenary, and straight or slightly curved (Text-fig. 13B, D). C-ray radial facet below level of others (Text-fig. 13A, C; PI. 6, figs. $1,4)$. C-ray anibrachial five-sided, with height equal to that of underlying radial but of greater width, extending well beyond level of radial facets of adjoining rays (Text-fig. 13A, C; PI. 6, figs. 1, 4). Anibrachial supports long armlike anal appendage to left and arm to right (Text-fig. 13A; Pl. 6, fig. 1). Anibrachial-anal-X suture longer and more steeply sloping than anibrachial-brachial suture. Anal X larger than proximal brachials, in contact with C-ray brachial, and supporting single series of rounded plates that become successively more elongate distally and extend beyond level of tertibrachials (Textfig. 13A; Pl. 6, figs. 1,3). Heights and widths of proximal 
anal plates equal; maximum widths of distal anal plates equal one-half of heights. Distal portion of anal appendage not preserved. Arms five, uniserial, apinnulate, branching at least three times. First bifurcation isotomous; higher bifurcations strongly heterotomous (Text-fig. 13A, B; Pl. 6, figs. 1, 2). Primibrachials three to six per taxis; last brachial in each taxis axillary. Secundibrachials four to six per taxis. One additional branching observed on fifth tertibrachial of holotype (ROM 39026). Heights and widths of proximal brachials equal; widths of distal brachials one-third of heights. Arms incompletely preserved.

Proxistele heteromorphic, round; diameter one-half that of cup. Lumen of proxistele columnals round; diameter one-third that of stem. Heights of proxistele and mesistele columnals one-quarter to one-third of widths. Mesistele columnals pentagonal with concavopentastellate lumen and five distinct pentameres; each pentamere with small, circular axial canal.

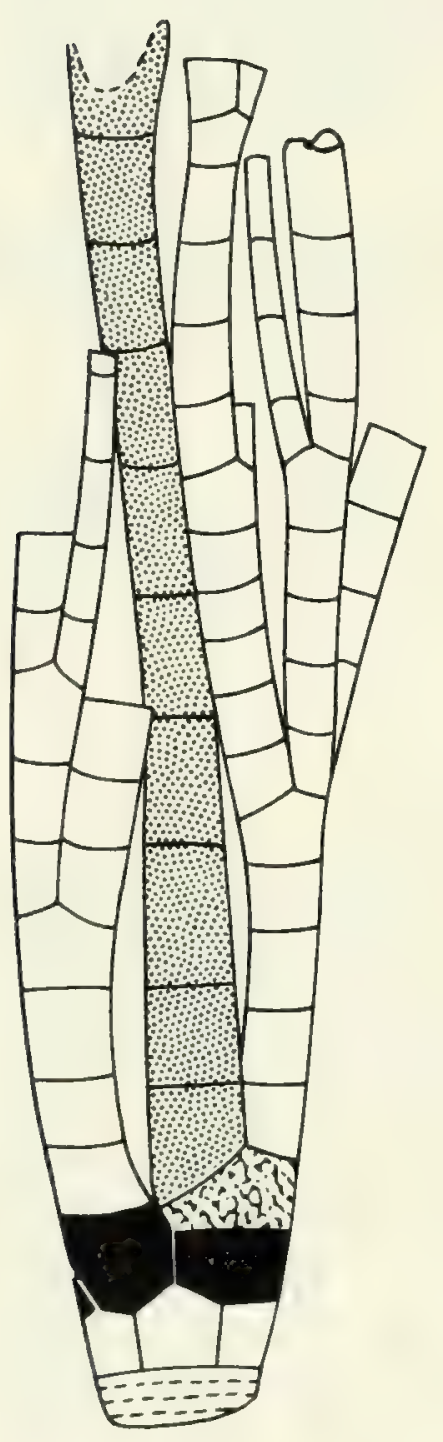

A

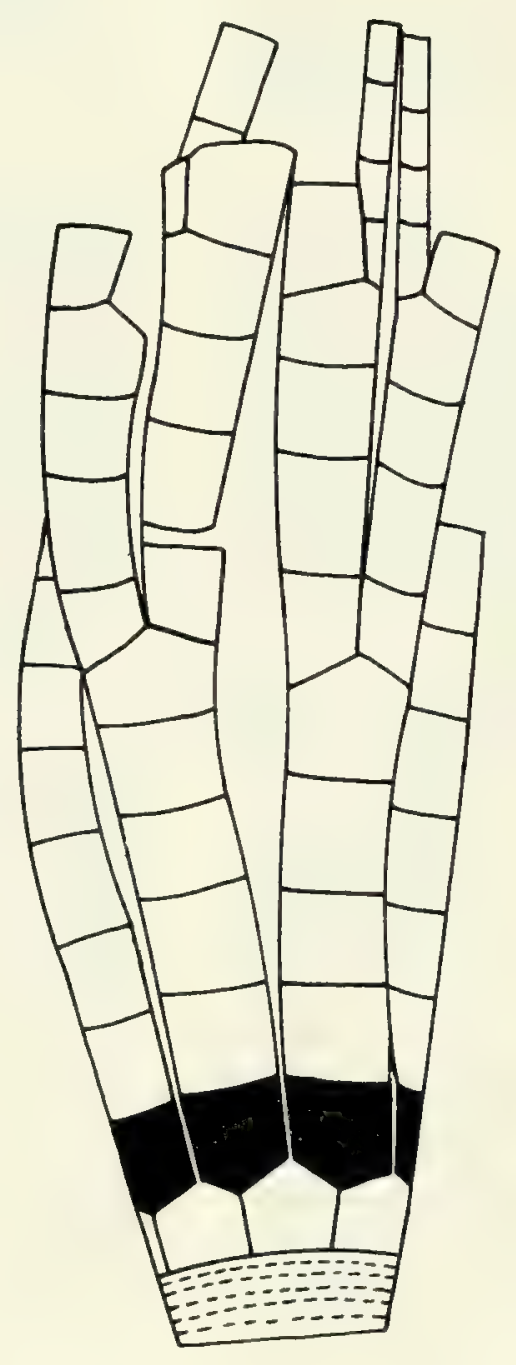

B
C
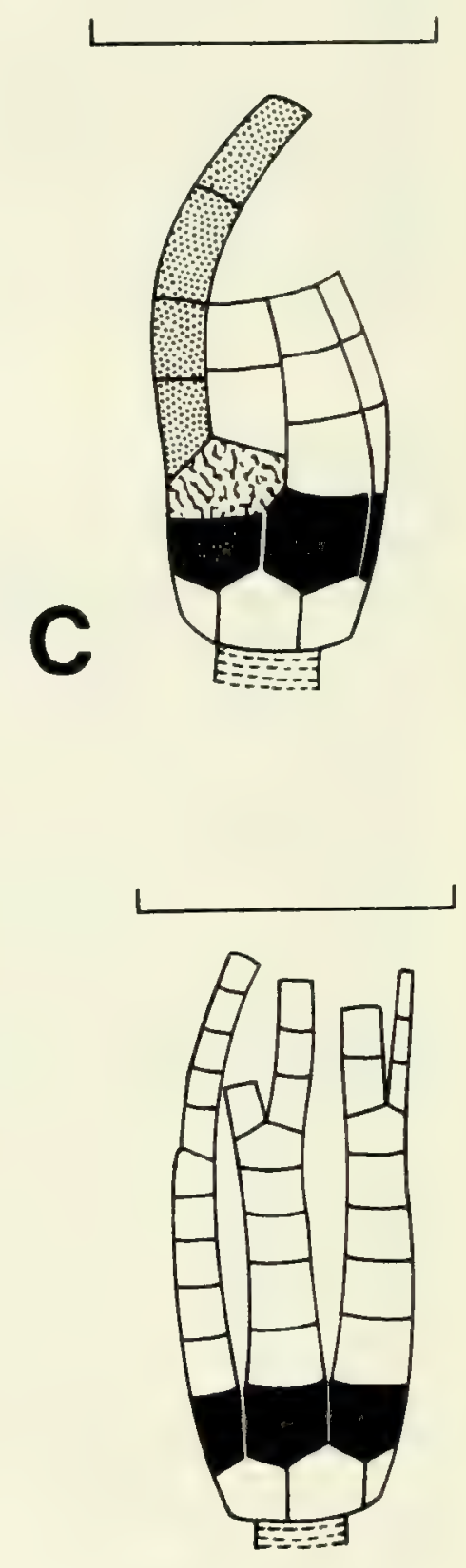

D

Text-fig. 13A-D Pariocrinus heterodactylus gen. et sp. nov.

Radials black; anibrachial wrinkle stipple; anals dot stipple. Scales $3 \mathrm{~mm}$.

A CD-interray of holotype. Note long anal appendage and strong heterotomy of higher branchings of arms, which are incomplete in this individual. ROM 39026, PI. 6, fig. 1.

B Anterior view of paratype ROM 39027, PI. 6, fig. 2.

C Right posterior view of paratype ROM 39029a, Pl. 6, fig. 4.

D Anterior view of paratype ROM $39028, \mathrm{Pl}$. 6, figs. 5, 6. 
Table 7 Measurements (in mm) of types of Pariocrinus heterodactylus gen. et sp. nov.

\begin{tabular}{|c|c|c|c|c|}
\hline Measurements & $\begin{array}{c}\text { Holotype } \\
\text { ROM } 39026\end{array}$ & $\begin{array}{c}\text { Paratype } \\
\text { ROM } 39027\end{array}$ & $\begin{array}{c}\text { Paratype } \\
\text { ROM } 39028\end{array}$ & $\begin{array}{c}\text { Paratype } \\
\text { ROM } 39029 a\end{array}$ \\
\hline Aboral cup height & 1.5 & 1.2 & 1.3 & 2.0 \\
\hline Aboral cup width & $2.0^{*}$ & $2.1 *$ & $2.2 *$ & $2.4^{*}$ \\
\hline Basal height & 0.71 & 0.62 & 0.69 & 0.78 \\
\hline Basal width & 0.74 & 0.65 & 0.77 & 0.83 \\
\hline Radial height & 0.91 & 0.74 & 0.79 & 0.97 \\
\hline Radial width & 0.98 & 0.67 & 0.78 & 0.98 \\
\hline C-ray radial height & 0.66 & - & - & 0.72 \\
\hline C-ray radial width & 1.0 & - & - & 0.94 \\
\hline Anibrachial height & 0.72 & - & - & 0.78 \\
\hline Anibrachial width & 1.2 & - & - & 1.2 \\
\hline Primibrachial, height & 0.59 & 0.69 & 0.58 & 0.76 \\
\hline Primibrachial, width & 0.75 & 0.71 & 0.78 & 0.85 \\
\hline Anal $\mathrm{X}$ height & 1.0 & - & - & 0.99 \\
\hline Anal $\mathrm{X}$ width & 0.82 & - & - & 0.53 \\
\hline $\mathrm{Anal}_{2}$ height & 0.87 & - & - & 0.79 \\
\hline $\mathrm{Anal}_{2}$ width & 0.82 & - & - & 0.53 \\
\hline Arm length & $10.5^{* *}$ & $7.8^{* *}$ & - & - \\
\hline Proximal stem diameter & 1.1 & 1.1 & 0.89 & 1.0 \\
\hline
\end{tabular}

* Measurement approximate owing to distortion of specimen.

** Distal portions of arms not preserved.

\section{Superfamily Homocrinacea Kirk, 1914 \\ Family Homocrinidae Kirk, 1914}

\section{Genus Homocrinus Hall, 1852}

\section{TYPE SPECIES}

Homocrinus parvus Hall, 1852, by monotypy.

\section{DIAGNOSIS}

Genus of Homocrinidae with small, steeply conical aboral cup. Basals five, pentagonal, elongate. Compound radials present in B-, C-, and E-rays. Anal X incorporated into cup between $\mathrm{C}$ - and D-ray superradials. One primibrachial in each ray incorporated into cup. Arms five, uniserial, apinnulate, unbranched, composed of greatly elongated brachials.

\section{KNOWN RANGE AND DISTRIBUTION}

Lower Silurian (Llandoverian), in southern Ontario. Upper Silurian (Wenlockian), in western New York State and southern Ontario.

\section{Homocrinus diminutus sp. nov.} Text-fig. 14; Pl. 6, figs. 7-9

\section{TYPE MATERIAL}

Six specimens were available for study: holotype ROM
39020; paratypes figured ROM 39021, 39022; paratypes unfigured ROM 39023 to 39025 inclusive.

\section{OCCURRENCE}

Cabot Head Formation, 1.1 m above base, at Ball's Falls on Twenty Mile Creek near Jordan, Ontario.

\section{ETYMOLOGY}

The specific name refers to the diminutive aboral cup of this species.

\section{DIAGNOSIS}

A species of Homocrinus with maximum aboral-cup height of $2 \mathrm{~mm}$. Proxistele round, nodal, heteromorphic.

\section{DESCRIPTION}

Height of crown approximately $15 \mathrm{~mm}$. Aboral cup very small, steeply conical. Basals five, pentagonal, elongate. Height of basal circlet approximately one-third that of cup. Compound radials present in B-, C-, and E-rays. Inferradials and superradials of equal size, quadrangular; heights equal to widths (Table 8). Superradial circlet 
Table 8 Measurements (in $\mathbf{m m}$ ) of type of Homocrinus diminutus sp. nov.

Holotype ROM 39020

\begin{tabular}{lclr}
\hline Aboral cup height & 0.74 & Primibrachial $_{1}$ height & 0.20 \\
Aboral cup width & 0.71 & Primibrachial $_{1}$ width & 0.27 \\
Basal height & - & Primibrachial $_{2}$ height & 0.78 \\
Basal width & - & Primibrachial $_{2}$ width & 0.26 \\
Inferradial height & 0.29 & Arm length & $12.0^{*}$ \\
Inferradial width & 0.29 & Proximal stem diameter & - \\
Superradial height & 0.29 & & \\
Superradial width & 0.30 & &
\end{tabular}

* Distal portions of arms not preserved.

extends nearly to top of cup (Text-fig. 14; Pl. 6, figs. 8 , 9). Each superradial supports fixed, small, quadrangular primibrachial of equal height and width. Posterior interray not exposed in type material. Arms five, relatively long, uniserial, apinnulate, unbranched, composed of greatly elongated brachials ( $\mathrm{Pl} .6$, figs. 7-9).

Column incompletely preserved. Stem threadlike in appearance, enlarging slightly below cup. Proxistele heteromorphic, composed of alternating nodal and internodal columnals. Heights of columnals one-half to one-third of widths. Nodals slightly wider and higher than internodals.

\section{DISCUSSION}

Homocrinus diminutus sp. nov. is only the second species referrable to the genus Homocrinus. The type species, $H$. parvus, is known from the Upper Silurian (Wenlockian) Rochester Formation in western New York State and southern Ontario; it is also a small crinoid-maximum height of aboral cup is about $3 \mathrm{~mm}$-and is known from several hundred individuals from at least six localitiesproof that small size is characteristic of this species.

Homocrinus diminutus differs from the type species in possessing a lower basal circlet and a heteromorphic, rather than xenomorphic, column (compare Pl. 6, figs. 8, 10). The type specimens of $H$. diminutus are also considerably smaller than most individuals of $H$. parvus and would have been overlooked in the field had they not been found in association with asteroids and ophiuroids.

The phylogenetic position of Homocrinus diminutus is problematic. It may have been derived from an undiscovered Ordovician species. H. parvus may have descended from $H$. diminutus through undiscovered, intermediate species. Because it is inconspicuous, Homocrinus is easily overlooked in the field; it is probably, therefore, a more abundant and more widespread genus than is indicated at present.

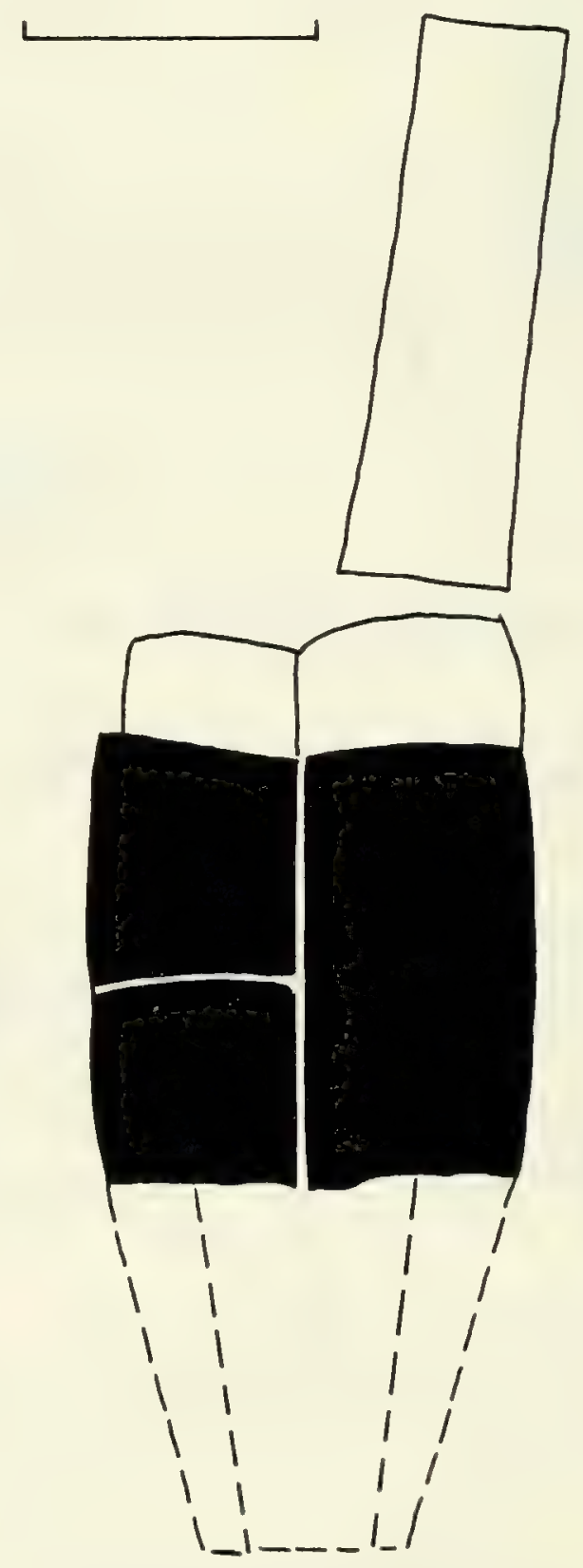

Text-fig. 14 Homocrinus diminutus sp. nov. Lateral view of holotype. Basals of this specimen are missing. Note single fixed primibrachial in each ray. ROM 39020, Pl. 6, fig. 9.

Inferradials and superradials black. Scale $0.5 \mathrm{~mm}$. 


\section{Order Cladida Moore and Laudon, 1943 \\ Suborder Dendrocrinina Bather, 1899 \\ Family Dendrocrinidae Wachsmuth and Springer, 1886}

Genus Dendrocrinus Hall, 1852

\section{TYPE SPECIES}

Dendrocrinus longidactylus Hall, 1852, by monotypy.

\section{DIAGNOSIS}

Genus of Dendrocrinidae with radianal situated directly below C-ray radial. Anal $\mathrm{X}$ incorporated into cup, positioned between $\mathrm{C}$ - and D-ray radials. Radial facets narrow, horseshoe-shaped, typically declivate. Arms apinnulate, branching repeatedly and isotomously. Anal sac prominent, tall, composed of regular plates.

\section{KNOWN RANGE AND DISTRIBUTION}

Middle Ordovician to Upper Silurian, in North America and Europe.

\section{DISCUSSION}

Brower (1973:452) noted that Dendrocrinus constitutes one of the most important dicyclic inadunate groups of the Ordovician. Nearly 20 species are known at present.

Dendrocrinus may be divided into two morphotypes: those characterized by aboral cups ornamented with
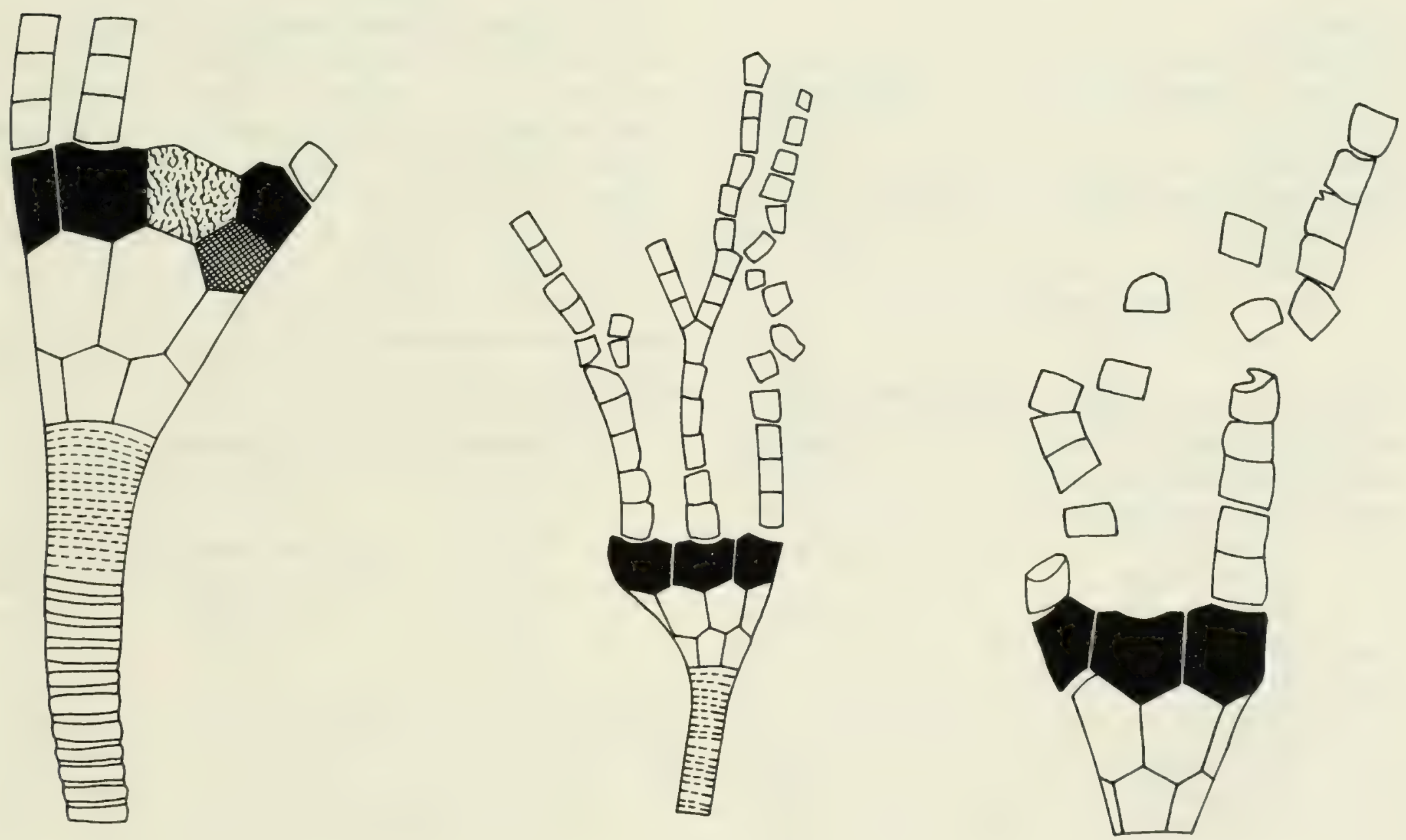

A

B

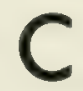

Text-fig. 15A-C Dendrocrinus parvus sp. nov.

Radials black; radianal ruled; anal X wrinkle stipple. Scales $5 \mathrm{~mm}$.

A CD-interray of holotype ROM 39037, PI. 7, fig. 3.

B Anterior view of paratype ROM 39038a, Pl. 7, fig. 4

C Anterior view of paratype ROM 39039, Pl. 7, fig. 5. 
heavy, single or multiple stellate ridges, typified by $D$. casei Meek and D. rugocyathus Ramsbottom; and those belonging to a larger group characterized by smooth, unornamented cups, typified by $D$. gregarius Billings, $D$. celsus Ringueberg, and many other species that are often difficult to differentiate from one another. $D$. parvus sp. nov. may be placed in the larger group.

The widespread distribution and numerous species of Dendrocrinus, and the variety of lithotopes associated with the genus, indicate that this genus was a highly adaptable crinoid. The writer believes that this adaptability is correlated with the modes of attachment that permitted the genus to colonize a variety of substrates (p. 46).

Dendrocrinus parvus sp. nov.

Text-fig. 15A-C; Pl. 7, figs. 3-6

\section{TYPE MATERIAL}

Eight specimens were available for study: holotype ROM 39037; paratypes figured ROM 39038a, b, 39039, 39043; paratypes unfigured ROM 39040 to 39042 inclusive.

\section{OCCURRENCE}

Cabot Head Formation, 2.1 and $6.4 \mathrm{~m}$ above base, at Ball's Falls on Twenty Mile Creek near Jordan, Ontario.

\section{ETYMOLOGY}

From the Latin, parvus - small - in reference to the small size of this species.

\section{DIAGNOSIS}

A species of Dendrocrinus characterized by small size and smooth, unornamented plates. Five or six primibrachials per ray. Tall, plicate anal sac. Stem heteromorphic and round proximally, becoming pentagonal distally.

\section{DESCRIPTION}

Height of incomplete crown approximately $40 \mathrm{~mm}$. Aboral cup small, steeply conical. Plates smooth, unornamented. Infrabasals five, pentagonal, slightly elongate, expanding distally. Height of infrabasal circlet about one-third that of cup. Basals five. EA-, AB-, and DE-interray basals hexagonal, higher than wide. $\mathrm{BC}$ interray basal hexogaonal; height equal to width. CDinterray basal septagonal, higher than wide, supporting anal X. Radianal located directly below C-ray radial; radianal pentagonal, with height equal to width (Text-fig. $15 \mathrm{~A}$; Pl. 7, fig. 3). Anal X six-sided; height equal to width. Anal $\mathrm{X}$ located above and to left of radianal, between $\mathrm{C}$ - and D-ray radials, and supporting tall anal sac composed of regular, plicate hexagonal plates (Pl. 7, fig. 6). Radials five, pentagonal; heights equal to widths (Table 9). Radial facets narrow, with widths about one-third widths of radials, horseshoe-shaped, slightly declivate. Arms five, apinnulate, branching isotomously. Primibrachials five or six per taxis, strongly rounded aborally, deeply grooved ventrally (Pl. 7, figs. 5, 6). Heights and widths of proximal brachials equal; distal brachials slightly elongate. A higher branching observed

Table 9 Measurements (in mm) of types of Dendrocrinus parvus sp. nov.

\begin{tabular}{lccc} 
Measurements & $\begin{array}{c}\text { Holotype } \\
\text { ROM } 39037\end{array}$ & $\begin{array}{c}\text { Paratype } \\
\text { ROM 39038a }\end{array}$ & $\begin{array}{c}\text { Paratype } \\
\text { ROM 39039 }\end{array}$ \\
\hline Aboral cup height & 3.4 & 2.0 & 3.1 \\
Aboral cup width & $3.7^{*}$ & $2.7^{*}$ & $3.4^{*}$ \\
Infrabasal height & 0.92 & 0.59 & 0.93 \\
Infrabasal width & 0.83 & 0.43 & 0.88 \\
Basal height & 1.6 & 0.80 & 1.5 \\
Basal width & 1.1 & 0.62 & 1.2 \\
Radial height & 1.1 & 0.74 & 1.2 \\
Radial width & 1.1 & 0.90 & 1.3 \\
Radianal height & 0.89 & - & - \\
Radianal width & 1.0 & - & - \\
Anal X height & 1.0 & - & - \\
Anal X width & 1.2 & - & - \\
Primibrachial, height & 0.60 & 0.52 & 0.67 \\
Primibrachial, width & 0.51 & 0.48 & 0.77 \\
Arm length & - & $13.0^{* *}$ & $7.4^{* *}$ \\
Proximal stem diameter & 1.4 & 0.77 & 1.1 \\
\hline
\end{tabular}

* Measurement approximate owing to distortion of specimen.

** Distal portions of arm not preserved. 
on ninth secundibrachial of one individual (ROM 39038a). Distal portions of arms not preserved.

Column round proximally, becoming pentagonal distally, heteromorphic, composed of alternating thick and thin columnals. Dististele and holdfast unknown.

\section{DISCUSSION}

Dendrocrinus parvus sp. nov. may be readily differentiated from the Upper Silurian type species $D$. longidactylus Hall because it has relatively wide radial facets, fewer arm branches, and a different stem morphology, and is much smaller in size than the latter. Plicate anal plates, fewer primibrachials, and a different stem morphology distinguish the new species from $D$. celsus Ringueberg. The subequal or slightly elongate brachials of $D$. parvus differentiate this species from the British Llandovery form D. extensidiscus Brower, which is characterized by greatly elongate brachials. The rounded brachiais of $D$. parvus contrast with the narrow-backed brachials of the Trenton species $D$. acutidactylus Billings and $D$. proboscidiatus Billings. $D$. parvus has a heteromorphic column, in contrast to the undifferentiated columnals of $D$. dyeri (Meek) of Kentucky and Ohio. $D$. parvus lacks the pentameric columnals of the Cincinnatian species Quinquecaudex cincinnatiensis (Meek).

Subclass Flexibilia Zittel, 1895

Order Taxocrinida Springer, 1913

Superfamily Taxocrinacea Angelin, 1878

Family Taxocrinidae Angelin, 1878

\section{Genus Protaxocrinus Springer, 1906}

\section{TYPE SPECIES}

By designation of Springer, 1906:515; Taxocrinus ovalis Angelin, 1878.

\section{EMENDED DIAGNOSIS}

Genus of Taxocrinidae with elongate crown and isotomously branching arms that do not abut laterally. Basals visible in side view. Radianal situated directly below C-ray radial and resembles an inferradial. Anal tube prominent; proximal portion sutured to C-ray brachials. Primibrachials two or three. Interbrachials absent or few in number, small.

\section{KNOWN RANGE AND DISTRIBUTION}

Middle Ordovician to Lower Devonian, in North America and Europe.

\section{DISCUSSION}

All previously described species of Protaxocrinus have two primibrachials in each ray. The generic diagnosis is here emended to accommodate $P$. cataractensis sp. nov., which has two or three primibrachials in each ray.

\section{Protaxocrinus cataractensis sp. nov.} Text-fig. 16A-C; Pl. 8, figs. 1-9

\section{TYPE MATERIAL}

Four specimens were available for study: holotype ROM 39003, paratypes figured ROM 39004 to 39006 inclusive.

\section{OCCURRENCE}

Cabot Head Formation, 1.3 and $3.0 \mathrm{~m}$ above base, at Ball's Falls on Twenty Mile Creek near Jordan, Ontario.

\section{ETYMOLOGY}

The specific name is derived from occurrence of this species in strata of the Cataract Group.

\section{DIAGNOSIS}

A species of Protaxocrinus characterized by a narrow aboral cup and low infrabasal circlet. Primibrachials two or three per ray. Arms branching three or four times; brachials rounded with smooth sides. Plates smooth, unornamented.

\section{DESCRIPTION}

Crown of small size, with maximum height approximately $21 \mathrm{~mm}$. Aboral cup steeply conical, expanding from stem axis at approximately $30^{\circ}$. Plates smooth, unornamented. Infrabasal circlet low, with height one-fifth that of cup, composed of three plates-two large and one small. Azygous infrabasal located in CD-interray. Infrabasals pentagonal; heights of two larger infrabasals one-half of widths (Table 10); height of azygous infrabasal two-thirds of width. Basal circlet high, with height two-fifths that of aboral cup. Basal that supports radianal is hexagonal, slightly elongate. Radial circlet high; height approximately equal to that of basal circlet. Radials typically pentagonal, wider than high; distal edges truncated to accommodate interbrachials. Radial facets plenary, gently 


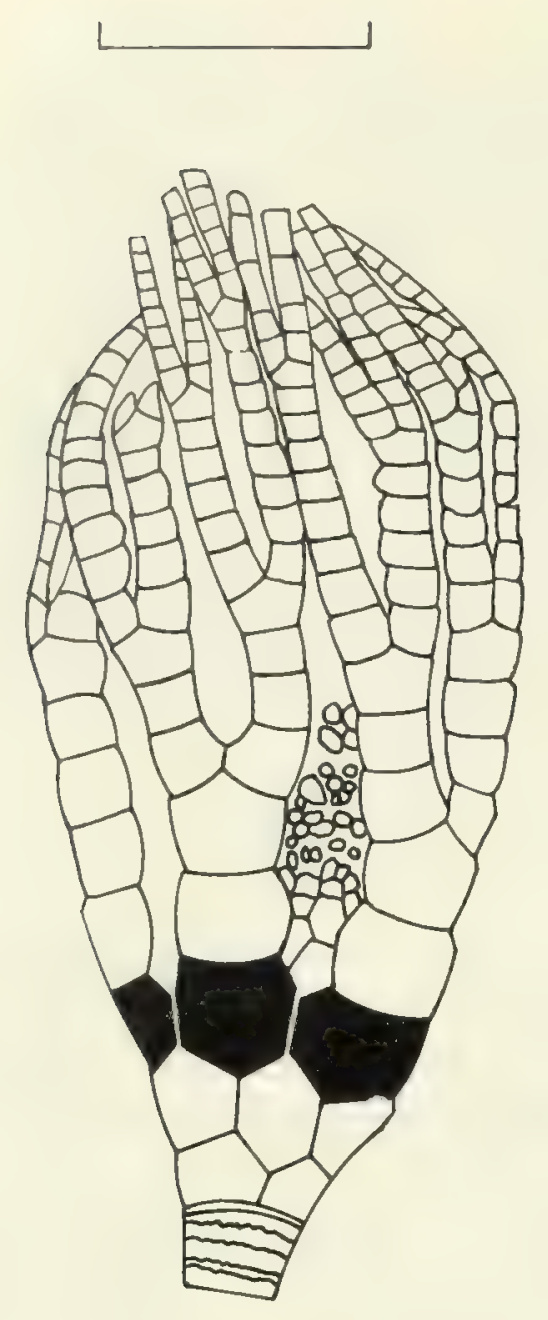

A
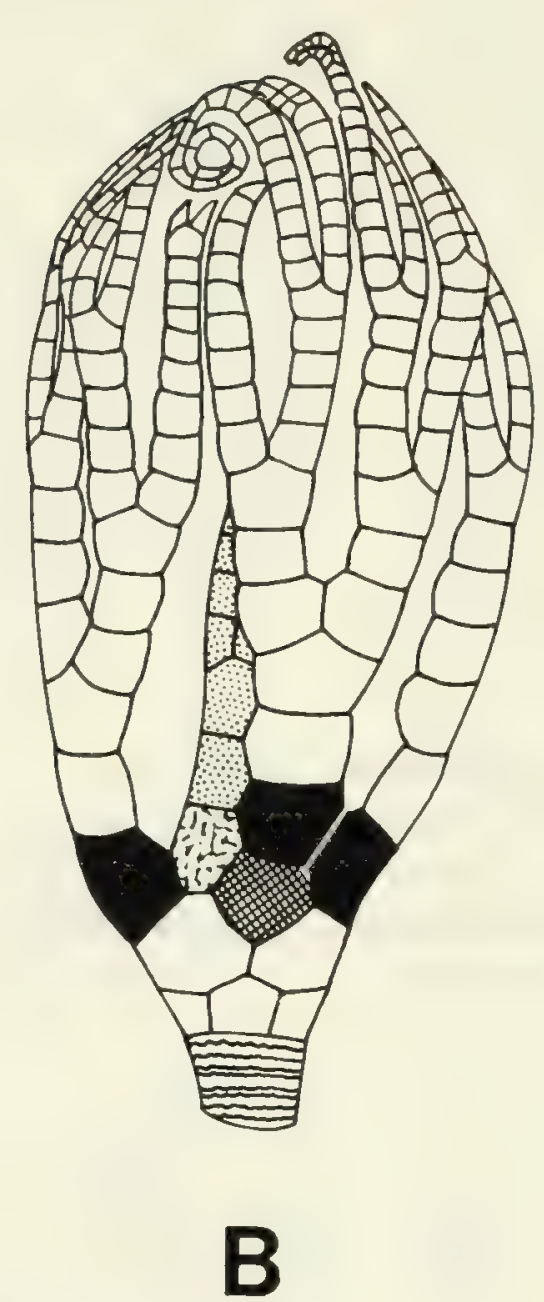

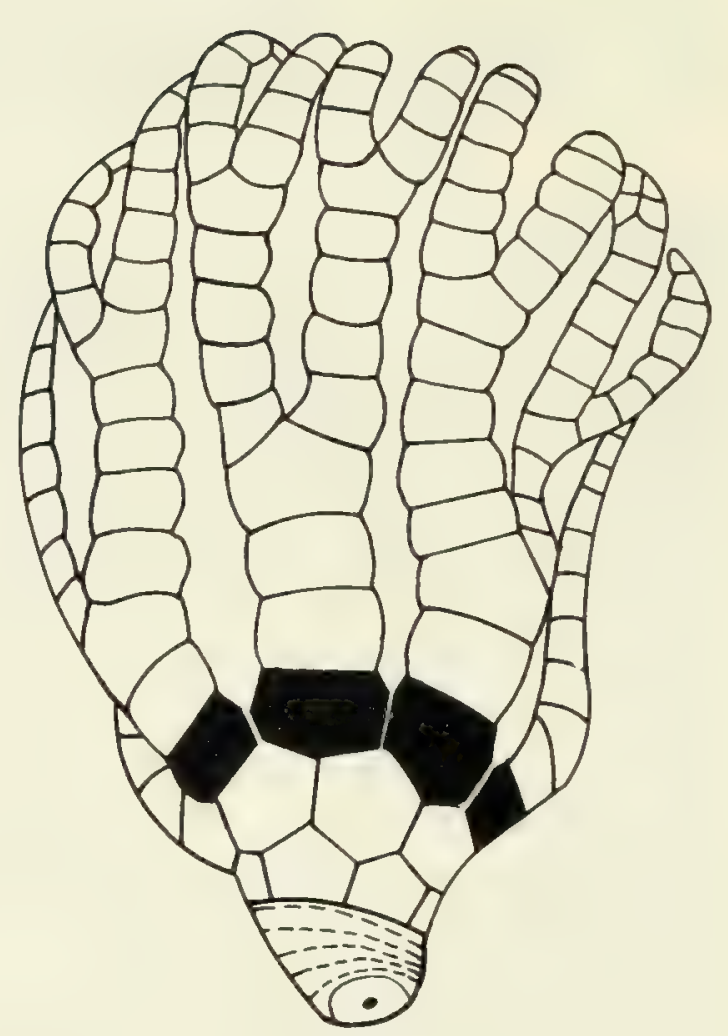

C

Text-fig. 16A-C Protaxocrinus cataractensis sp. nov.

Radials black; radianal ruled; anal X wrinkle stipple; higher anals dot stipple. Scales $10 \mathrm{~mm}$.

A Anterior view of holotype, showing irregular perisomic plates. ROM 39003, Pl. 8, fig. 8.

B CD-interray of holotype. Proximal portion of anal tube is sutured to C-ray. ROM 39003, Pl. 8, fig. 7.

C Anterior view of individual centred on A-ray. A-ray has three primibrachials; B- and E-rays each have two primibrachials.

Paratype ROM 39005, Pl. 8, fig. 5.

curved (Pl. 8, fig. 9). Radianal pentagonal, with height equal to width, lying below C-ray radial, adjoining anal $\mathrm{X}$ and BD-interray basals. Anal X hexagonal, with height equal to width, adjoining C- and D-ray radials and the underlying basal. Anal tube long, narrow; proximal portion sutured to C-ray. Proximal anal plates irregular, polygonal, becoming smaller and more numerous distally (Text-fig. 16B; Pl. 8, fig. 7). Interbrachials small, diamond-shaped, overlying truncated distal facets of radials ( $\mathrm{Pl} .8$, fig. 3), incorporated into cup, followed by irregular perisomic plates that become smaller distally and extend beyond secundaxillaries (Text-fig. 16A; PI. 8, figs. $3,9)$. Arms composed of smooth, rounded brachials with gently curved sides. Proximal brachials wider than high; distal brachials equidimensional to twice as high as wide. Proximal brachials of adjacent rays not in contact. Sutures between brachials slightly sinuous, depressed. Axillaries pentagonal, with gently to strongly curved distal facets that each produce a spear-shaped projection. Distal width of axillary slightly greater than its proximal width. Arms branching isotomously three or four times. Primibrachials two or three per taxis-variation in individuals. Secundibrachials three to five; tertibrachials six to 12 ; quartibrachials absent or few in number. Distal portions of arms not preserved or hidden from view.

Proxistele round, enlarging next to calyx, composed of alternating thick and thin columnals (Text-fig. 16A; Pl. 8, fig. 8). Heights of columnals approximately one-twentieth to one-fifth of widths. Columnals slightly wedge-shaped in one specimen (ROM 39005: Text-fig. 13C; Pl. 8, fig. 5). Sutures crenulate, symplexial. Lumen small, pentastellate; diameter approximately one-tenth that of stem at $2 \mathrm{~mm}$ below calyx. Mesistele and dististele unknown.

\section{DISCUSSION}

The infrabasal circlet of Protaxocrinus cataractensis is lower than that of many species of Protaxocrinus. These include the Middle Ordovician species $P$. elegans (Bil- 
lings) and $P$. laevis (Billings), both from Ontario, and the Upper Ordovician form $P$. girardeau Springer. $P$. cataractensis lacks the angular brachials and abundant interbrachials of $P$. elegans and is smaller; it also lacks the stout anal tube of $P$. laevis. The arms of $P$. cataractensis branch a minimum of three times in contrast to the two or three bifurcations of the arms of $P$. girardeau. $P$. cataractensis has three to five secundibrachials in contrast to the four to six corresponding plates on $P$. girardeau. The Upper Silurian species $P$. amii Bolton has a lower infrabasal circlet than $P$. cataractensis. $P$. virginiensis Springer has fewer secundibrachials than $P$. cataractensis. $P$. robustus Springer has more robust arms. The European species $P$. interbrachiatus (Angelin) and $P$. ovalis (Angelin) have angular-sided brachials, rather than the smooth plates of $P$. cataractensis.

Occurrence of three primibrachials in one or more rays of individuals of Protaxocrinus cataractensis sp. nov. is unusual. Many early crinoid researchers assumed there was intraspecific constancy in the number of primibrachials and used this feature as an important taxobase. Warn and Strimple (1977) noted that intraspecific variability in numbers of primibrachials has seldom been documented for fossil crinoids, with the exception of cincinnaticrinids and Eutaxocrinus wideneri. Eutaxocrinus typically has two primibrachials in each ray, but four of 21 specimens of $E$. wideneri studied by Kesling and Strimple (1971) have one or three primibrachials in one or more rays. Interestingly, this genus is also a taxocrinid. Similar variability occurs in certain genera of Mississippian flexibles. Gnormocrinus individuals may have two or three primibrachials in each ray, and three to six primibrachials occur in specimens of Onychocrinus (Springer, 1920). Many inadunate lineages, including dendrocrinids, display similar variability (personal observation). To the writer's knowledge, similar variation has not been documented for the fixed primibrachials of camerates, although elimination of first primibrachials appears to have occurred in some specimens of the Mississippian camerate Alloprosallocrinus (Van Sant and Lane, 1964).

The writer hypothesizes that genetic coding for numbers of primibrachials in camerates was rigid because variability from ray to ray would drastically affect the cup symmetry and the geometry of internal organs. In flexible crinoids, however, the primibrachials did not form part of the wall of the cup, and numerical variability did not significantly affect structure. Similar intraspecific variation in inadunates had no effect on the geometry of the cup since the primibrachials are typically free above the radials.

Protaxocrinus cataractensis was probably derived from an Ordovician species of Protaxocrinus. The low infrabasal circlet and the few interbrachials of this form indicate evolutionary advancement, while the steeply conical cup remains as a primitive characteristic. As indicated on page 35, no other species of Protaxocrinus show variability in the number of primibrachials. $P$. cataractensis may represent an offshoot of the lineage that left no descendants.

Table 10 Measurements (in mm) of types of Protaxocrinus cataractensis sp. nov.

\begin{tabular}{|c|c|c|c|c|}
\hline Measurements & $\begin{array}{c}\text { Holotype } \\
\text { ROM } 39003\end{array}$ & $\begin{array}{c}\text { Paratype } \\
\text { ROM } 39004\end{array}$ & $\begin{array}{c}\text { Paratype } \\
\text { ROM } 39005\end{array}$ & $\begin{array}{c}\text { Paratype } \\
\text { ROM } 39006\end{array}$ \\
\hline Crown height & 21.2 & 20.3 & 15.2 & 14.6 \\
\hline Infrabasal height & 1.1 & 0.71 & 0.61 & 0.61 \\
\hline Infrabasal width & 2.3 & 1.4 & 1.3 & 1.3 \\
\hline Basal height & 2.0 & 1.3 & 1.5 & 1.1 \\
\hline Basal width & 1.9 & 1.4 & 1.5 & 1.3 \\
\hline Radial height & 1.9 & 1.4 & 1.4 & 0.89 \\
\hline Radial width & 2.2 & 2.2 & 2.0 & 1.5 \\
\hline Radianal height & 1.9 & 0.91 & 1.2 & - \\
\hline Radianal width & 2.2 & 1.4 & 1.6 & - \\
\hline Anal X height & 1.6 & - & 1.1 & - \\
\hline Anal $\mathrm{X}$ width & 1.3 & - & 1.2 & - \\
\hline Axillary, height & 1.8 & 1.3 & 1.2 & 1.2 \\
\hline Axillary, width & 2.1 & 2.2 & 1.9 & 1.3 \\
\hline Proximal stem diameter & 2.3 & 2.1 & 2.2 & 1.6 \\
\hline
\end{tabular}




\author{
Class Stelleroidea Lamarck, 1816 \\ Subclass Asteroidea de Blainville, 1830 \\ Order Valvatida Perrier, 1884 \\ Suborder Pustulosina Spencer, 1951 \\ Superfamily Promopalaeasteraceae Schuchert, 1914 \\ Family Promopalaeasteridae Schuchert, 1914
}

\title{
Genus Promopalaeaster Schuchert, 1914
}

\section{TYPE SPECIES}

By designation of Schuchert (1914); Palaeaster speciosus Meek, 1872.

\section{GENERIC DIAGNOSIS}

Asteroids with all external ossicle surfaces having numerous, prominent spine-base pustules, each pustule carrying or having carried a single articulating spine; paxillae never present. All primary columns of ossicles prominent throughout life. Intermarginals and adradial ossicles arranged in longitudinal columns as well as transverse rows. More prominent transverse rows of intermarginals alternate with less prominent ones. Podial pores abradial to ambulacral ossicle bodies at junctions of ambulacral and adambulacral ossicle columns. Proximal podial cupules quadriserial; distal podial cupules biserial.

[Taken from Branstrator, 1979]

\section{KNOWN RANGE AND DISTRIBUTION}

Middle Ordovician to Lower Silurian, in North America and Europe.

Promopalaeaster? granti (Spencer) 1884, n. comb. Text-fig. 17A-E; Pl. 9, figs. 1-8; Pl. 10, fig. 5

Palaeaster granti Spencer, 1884:53, pl. 7, fig. 1. Mesopalaeaster granti Schuchert, 1915:89, 90, pl. 9, fig. 3.

Mesopalaeaster? cataractensis Schuchert, 1915:89, pl. 9, fig. 2 .

\section{TYPE MATERIAL}

Nineteen specimens were available for study: hypotypes figured ROM 39029b, 39059 to 39064 inclusive; specimens unfigured ROM 39067 to 39078 inclusive.

\section{OCCURRENCE}

Cabot Head Formation, $1.1 \mathrm{~m}$ and $3.0 \mathrm{~m}$ above base, at Ball's Falls on Twenty Mile Creek near Jordan, Ontario.

\section{DIAGNOSIS}

Disc proportionately large. Rays with small interbrachial arcs, tapering uniformly distally. All ossicles except ambulacrals tuberculate. Radial, superomarginal, and marginal columns separated by smaller accessory ossicles in adults. Madreporite small, round, striate. Mouth-angle plates prominent, triangular, elongate. Ambulacrals lathshaped, each with a diagonal keel. Proximal podial cupules quadriserial; distal podial cupules biserial.

\section{DESCRIPTION}

Body stellate and small with short arms, about $2 \mathrm{~cm}$ across; disk less than $1 \mathrm{~cm}$ wide, and apparently formed by the junction of the rays; rays $5 \mathrm{~mm}$ wide at base, tapering slowly, and terminating in rounded extremities, at about $8 \mathrm{~mm}$ from junction of their base with the disk; upper surfaces of rays composed of five [not less than nine in mature specimens at mid-length of rays] ranges of highly convex or tuberculiform plates [the marginal (supramarginal) and ventral (inframarginal) rows being the most conspicuous] and separated from each other by minute plates [becoming fewer on approaching the extremities of the rays].

The ellipsoid [supra] marginal tuberculiform plates number about 12 [20 in mature examples] for each complete side of the rays, and the central range [radial] is composed of a similar number, but in form these plates are more circular. The disk between the terminal central [radial] row of plates of the rays is crushed and structureless, except a slight elevation in the center. The terminal [proximal] plates of the marginal series are larger than the others of the range. The madreporoform tubercule is of spherical form and relatively large, being nearly $2 \mathrm{~mm}$ in diameter, and is situated at the axil of two rays. Both the tuberculiform plates and the madreporiform tubercule have a granulated surface.

The ventral side is unknown.

[Taken from Spencer, 1884, as quoted in Schuchert, 1915]

\section{EMENDED DESCRIPTION OF ADULTS}

Body stellate, small, with diameter of about $3 \mathrm{~cm}$. Disc formed by junction of rays. Width of disc approximately one-third of overall diameter. Interbrachial arcs absent except in gerontic individuals, where they are small. Rays five, tapering slowly and uniformly to pointed extremities. Borders of each brachium form enclosed angle of $25^{\circ}-30^{\circ}$. Adorally each ray consists of tuberculate radial, superomarginal, and marginal columns that extend to 


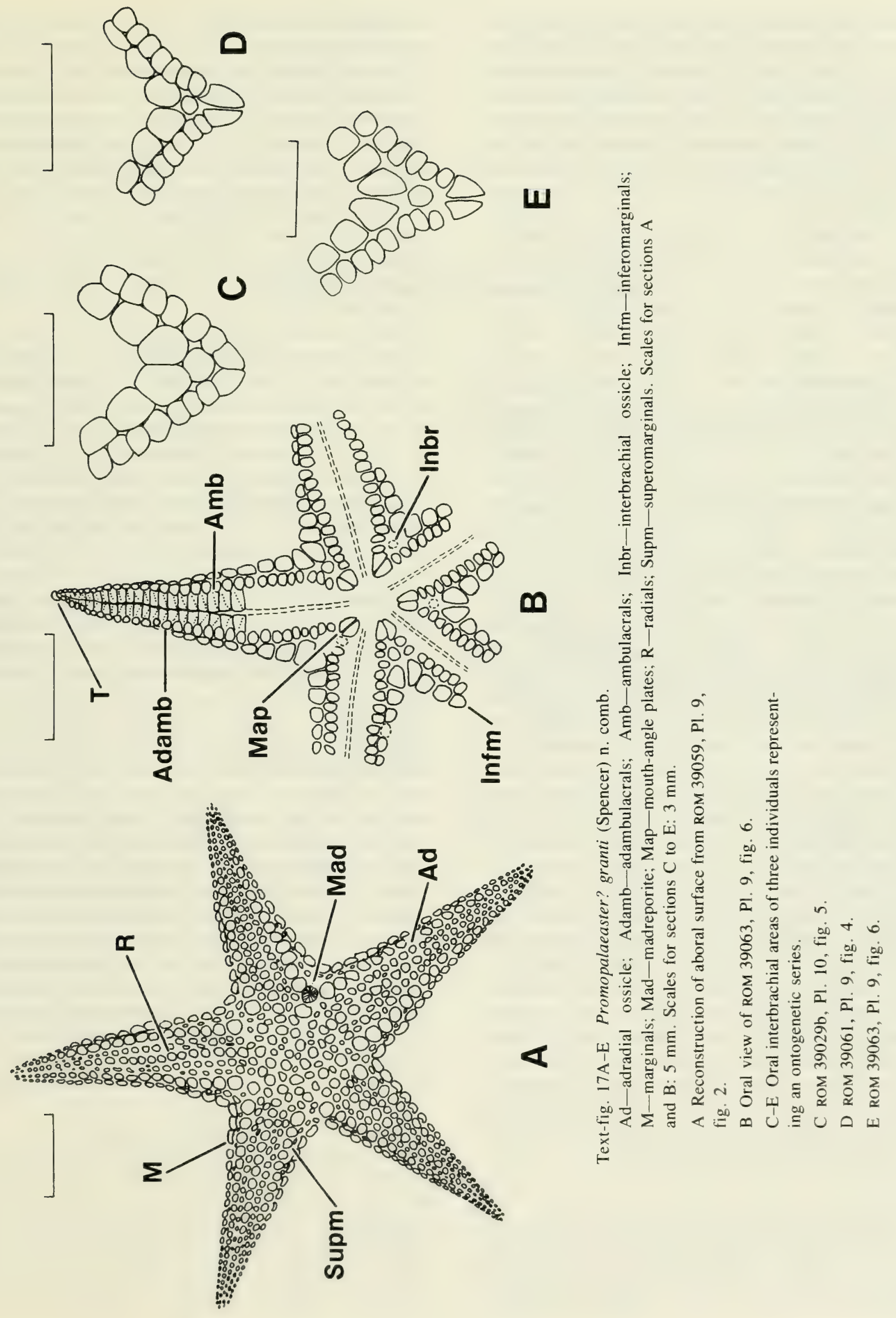


distal extremities of rays. Columns poorly differentiated from intercalated accessory ossicles (Text-fig. 17A; PI. 9, figs. 2, 5). These ossicles apparently bore spines not preserved in study material. Radial ossicles round, small, tumid, 20 to 30 per ray. Proximal radial ossicle largest in series. Radial columns bounded by one or two rows of smaller, irregular accessory ossicles that do not extend to extremities of rays (Text-fig. 17A; Pl. 9, fig. 2). A narrow row of not more than six intermarginal accessory ossicles may occur between superomarginal and marginal columns of large individuals (Pl. 9, fig. 5). Superomarginals slightly larger than radials and highly convex. Proximal superomarginal largest in series. Superomarginals partly overlapping marginals, cryptozonate. Narrow, discontinuous row of tiny, irregular ossicles may be present between superomarginal and marginal columns (Pl. 9, figs. 2, 5). Centres of discs collapsed and poorly preserved, composed of large and small ossicles without discernible pattern (Pl. 9, fig. 5). Madreporite distinct, located near junction of two rays, round, striate, no larger than and not overlapping adjacent ossicles (Text-fig. 17A; PI. 9, figs. 2, 3).

Orally, each ray consists of ambulacral, adambulacral, and inferomarginal columns. Mouth-angle plates prominent, triangular, elongate, paired (Text-fig. 17B; Pl. 9, figs. 2, 6). Single, small, round, tumid interbrachial ossicle in each arc enclosed by adambulacrals and inferomarginals and bounded laterally by two to four pairs of adambulacrals (Text-fig. 17C-E). Each ambulacral elliptical, with major axis directed laterally. Ambulacrals strongly tumid, without spines in type material, and numbering 35 to 40 in each column. Terminal (ocular) ossicle preserved in one specimen, round, larger than adjoining adambulacrals (Text-fig. 17B; PI. 9, fig. 7). Inferomarginals larger than adambulacrals, tuberculate; spines not preserved in type specimens. Proximal inferomarginals are largest adoral ossicles, trigonal with rounded extremities, flattened adorally. Adjacent inferomarginals quadrangular with rounded extremities. Distal inferomarginals circular, tumid, not extending to the apex of each ray. Ambulacral grooves wide, not covered by adambulacrals, tapering proximally at junction of mouth-angle plates. Each ambulacral groove composed of two rows of lath-shaped, concavo-convex ambulacral ossicles with concave surface directed adorally. Ambulacrals placed in opposite arrangement, each with a diagonal keel (Text-fig. 17B; Pl.9, fig. 6). Proximal podial cupules quadriserial; distal podial cupules biserial.

\section{DISCUSSION}

The repository of the type material of Palaeaster granti collected at Hamilton, Ontario, is uncertain. Specimens deposited at the University of Missouri were apparently destroyed by fire (Schuchert, 1915). It may be necessary to designate neotypes should the type specimens prove to be unavailable for study.

Palaeaster granti was reassigned to Mesopalaeaster (Schuchert, 1915). Specimens of the type species, Mesopalaeaster shafferi (Hall), show a one to one ratio of ossicles in adjacent adambulacral and inferomarginal columns (Branstrator, 1979). Promopalaeaster? granti individuals, however, typically possess a two to one ratio of these ossicles (two adambulacrals for each inferomarginal ossicle). This difference indicates that Promopalaeaster? granti is not congeneric with Mesopalaeaster, which at present is considered to be monotypic (Branstrator, 1979).

Promopalaeaster? granti is assigned to Promopalaeaster with reservation. Individuals do not display the transverse rows of ossicles typical of Promopalaeaster species. The arrangement of the intermarginals (accessory ossicles between superomarginal and marginal columns) is also different. According to Branstrator (1979), a biserial intermarginal condition (a row of small ossicles intercalated between each row of larger ossicles) is common to all promopalaeasterids. The intermarginal ossicles of Promopalaeaster? granti individuals, however, are typically arranged in a single row composed of ossicles of approximately equal size. These differences may, in part, reflect the small size of Promopalaeaster? granti individuals. The largest specimens have a maximum brachium length of $16 \mathrm{~mm}$ while that of the holotype of $P$. speciosus (Meek) is $44 \mathrm{~mm}$.

\section{ONTOGENY}

Palaeozoic asteroids are generally rare fossils and accordingly, descriptions of many genera and species have been based on few individuals. The fortunate discovery of a nearly complete growth series of Promopalaeaster? granti permits differentiation of taxonomic and ontogenetic features. The morphology of this species changed greatly through ontogeny. The brachia of small (less than $2 \mathrm{~cm}$ in diameter) individuals possess few or no accessory ossicles aborally (compare Pl. 9, figs. 1, 5). The madreporite is typically not apparent in small individuals. Orally, the interbrachial ossicles of juveniles and adults are almost identical in size. Each is bounded laterally by a single pair of adambulacrals in juveniles but by up to four pairs of plates in large individuals (Text-fig. 17C-E). Growth series of Devonaster eucharis (Hall) reveal similar patterns (Hall, 1868; Ruedemann, 1916).

The ambulacra of young individuals of Promopalaeaster? granti are narrow and are not constricted proximally, unlike the wide ambulacra of adults. The inferomarginals of juveniles are more tumid, more rounded, and fewer in number than those of adults (compare Pl. 9, figs. 4, 5). Juveniles possess strongly convex, elevated rays and raised discs, whereas on large individuals the rays are 
typically flattened and the discs sunken. This last difference is thought to be partly of taphonomic origin. Presumably, the wider ambulacra of an adult did not resist compaction as well as the narrow ambulacra of juveniles, and decay of the larger disc led to its collapse.

It is probable that morphology of many Palaeozoic asteroids changed greatly during ontogeny. This in turn casts doubts on classification of many fossil asteroids, particularly genera and species established from few individuals. Undoubtedly, the taxobases of some genera are established from juveniles. Juveniles and adults of the same species could easily be classified as different species or even as different genera. For example, the type specimen of Mesopalaeaster? cataractensis Schuchert is a juvenile individual of Promopalaeaster? granti.

\section{Superfamily Palaeasteraceae Miller, 1889 \\ Family Mesopalaeasteridae Schuchert, 1914}

\section{Medinaster gen. nov.}

\section{TYPE SPECIES}

Medinaster orbiculus sp. nov.

\section{ETYMOLOGY}

The generic name is derived from the town of Medina, in reference to occurrence of this genus in Medinan deltaic strata, and from the Greek aster-star.

\section{DIAGNOSIS}

Asteroids with external ossicle surfaces having numerous spine-bearing pustules. Primary columns of ossicles prominent. Adradial ossicles arranged in poorly defined longitudinal rows without biserial arrangement. Transverse rows of ossicles not apparent. Intermarginal and adradial ossicles irregular in shape, with shardlike appearance. Madreporite prominent in adult individuals.

\section{DISCUSSION}

Three specimens of this starfish were discovered during the excavation of an occurrence of Kylixocrinus. The proportionately large disc, robust arms, differentiated aboral ossicles, large madreporite, and robust inferomarginal frame indicate that these individuals are not congeneric with Promopalaeaster? granti. They appear to be allied with the Devonian genus Devonaster. Devonaster, however, possesses brachia with gently curved sides, a much smaller madreporite of a different shape, elliptical rather than irregular aboral ossicles, and undifferentiated proximal superomarginals

\section{Medinaster orbiculus sp. nov.} Text-fig. 18A-C; PI. 10, figs. 1-4

\section{TYPE MATERIAL}

Three specimens were available for study: holotype ROM 39056, paratype figured ROM 39057, paratype unfigured ROM 39058.

\section{OCCURRENCE}

Cabot Head Formation, $6.4 \mathrm{~m}$ above base, at Ball's Falls on Twenty Mile Creek near Jordan, Ontario.

\section{ETYMOLOGY}

The specific name is derived from the Latin orbiculus, diminutive of orbis - circle - in reference to the prominent circular madreporite of this species.

\section{DIAGNOSIS}

Disc proportionately large. Rays five, short, stout. Interbrachial arcs small. Radial, superomarginal, and marginal columns strongly differentiated from intercalated rows of shardlike accessory ossicles. Madreporite prominent. Inferomarginal frame robust.

\section{DESCRIPTION}

Adult individuals small; diameter not exceeding $35 \mathrm{~mm}$ in type material. Borders of each ray form enclosed angle of about $35^{\circ}$. Aborally each ray is composed of nontuberculate radial, superomarginal, and marginal columns strongly differentiated from intercalated rows of accessory ossicles (Text-fig. 18A; Pl. 10, fig. 1). Radials rounded, irregular in shape, numbering approximately 25 per ray. Proximal radial largest in series. Radial columns bounded laterally by two or three rows of much smaller, highly irregular adradial ossicles of shardlike appearance; adradial ossicles do not extend to extremities of rays (PI. 10, fig. 1). Proximal superomarginals are largest aboral ossicles, trigonal in shape, each paired with corresponding plate of adjoining ray. Three large, rounded ossicles border each pair of proximal superomarginals towards the centre of disc, forming equilateral triangle. Superomarginals partly overlap marginals. Narrow row of intermarginals present. Marginal ossicles rounded, elliptical, more regular in shape than radials. Centre of disc composed of large and small ossicles without discernible pattern. Madreporite located near junction of two rays. Madrepor- 
ite unusually large, overlapping adjacent ossicles, circular, elevated with depressed centre, and marked with radiating, dendritic grooves (PI. 10, fig. 4).

Orally, each brachium composed of ambulacral, adambulacral, and inferomarginal columns. Mouth-angle plates prominent, elongate, paired. Single small, round interbrachial ossicle in each arc, enclosed by inferomarginals and bounded laterally by several pairs of adambulacrals (Text-fig. 18C; Pl. 10, fig. 2). Each adambulacral quadrangular to ellipsoid, with major axis at right angles to ambulacrum. Inferomarginals robust, much larger than adambulacrals, with spine-based pustules present. Proximal inferomarginals quadrangular and flattened proximally, circular distally, with about 15 ossicles present per column. Ambulacral grooves wide and constricted at junction of mouth-angle plates. Each ambulacral groove composed of two rows of lath-shaped concavo-convex ossicles placed in opposite arrangement (Text-fig. 18C; Pl. 10, fig. 2).

\section{Palaeoecology}

In Ontario the Cabot Head and Manitoulin formations are characterized by a rich and varied fauna of fossil invertebrates at most localities. Bolton (1957) lists 134 species from these strata. Equivalent strata in the eastern Niagara Peninsula and in New York State are impoverished in comparison. The Cabot Head Formation at DeCew Falls contains 36 species, each typically represented by few individuals (Bolton, 1957). A similar assemblage occurs at nearby Ball's Falls. In this area, clastics of the Cabot Head Formation were deposited in a prodeltaic regime unfavourable to many organisms.

The fauna of the Cabot Head Formation is largely derived from sandstone and siltstone lenses. This suggests that suitability of substrate was a controlling factor governing distribution of organisms on the sea floor. Sanci and silt may have provided firmer substrates for colonization than did finer clastics.

Rapid changes in sedimentation and amounts of suspended sediment were probably also important ecologic factors. Bolton (1957) noted that brachiopods collected from the Cabot Head Formation at DeCew Falls were smaller than representatives of the same species in other formations. This is also true of brachiopods and rugose corals at the Ball's Falls locality. Ptychocrinus medinensis, however, is typically represented by large, robust individuals. The abundance of this rheophilic feeder is indirect evidence that currents supplied foodladen, well-oxygenated water to the Ball's Falls area. The writer hypothesizes that many of the brachiopods died before they were fully mature as a result of high turbidity levels or of catastrophic burial. The distribution of bryozoans in these strata supports this hypothesis. Bolton (1957) reported 15 species of bryozoans from the Cabot Head Formation, but only two of these are found at DeCew Falls. Recent bryozoans are generally intolerant of large amounts of suspended sediment (Barnes, 1974). Ryland (1970) studied the distribution of bryozoans in the Mediterranean Sea. He noted that a sharp decrease in diversity and numbers of these organisms near the delta of the Rhône River off the southern coast of France coincided with an increase in sedimentation rates and amount of sediment in suspension. Rapid deposition of fine clastics killed these bryozoans directly by smothering. Such rapid sedimentation rates can indirectly limit the distribution of bryozoans by providing a soft substrate poorly suited for colonization.

Many Palaeozoic bryozoans appear to have been secondary inhabitants of substrates first colonized by opportunistic r-selective species, including certain brachiopods, which in turn provided suitable substrates for bryozoan colonization (Schopf, 1969; Walker and Parker, 1976; Brett, 1978b). Such autogenous successions (sensu Walker and Albertstadt, 1975) were inhibited in the Medinan deltaic regime because the pioneer individuals were smothered.

\section{PA!AEOECOLOGY OF THE CRINOID FAUNA}

The abundance and diversity of Palaeozoic crinoids in various lithotopes is evidence of their success in exploiting a wide variety of marine environments. The exceptional range in morphology encompassed by these organisms is a reflection of their adaptive ability. In turn, the study of the functional morphology of crinoids is facilitated by their well-skeletonized nature. The fine preservation of crinoids in the Cabot Head Formation further aids palaeoecologic analysis.

Platform carbonates and shale of the Manitoulin and Cabot Head formations in southern Ontario contain large numbers of brachiopods and bryozoans. Crinoids appear to have played a minor role in these communities. However, they are the most common fossils in equivalent prodeltaic strata at Ball's Falls. This suggests that the crinoids possessed features that conferred adaptive advantage in the prodeltaic regime.

The relative heights of organisms above the substrate may have been an important factor that governed their 


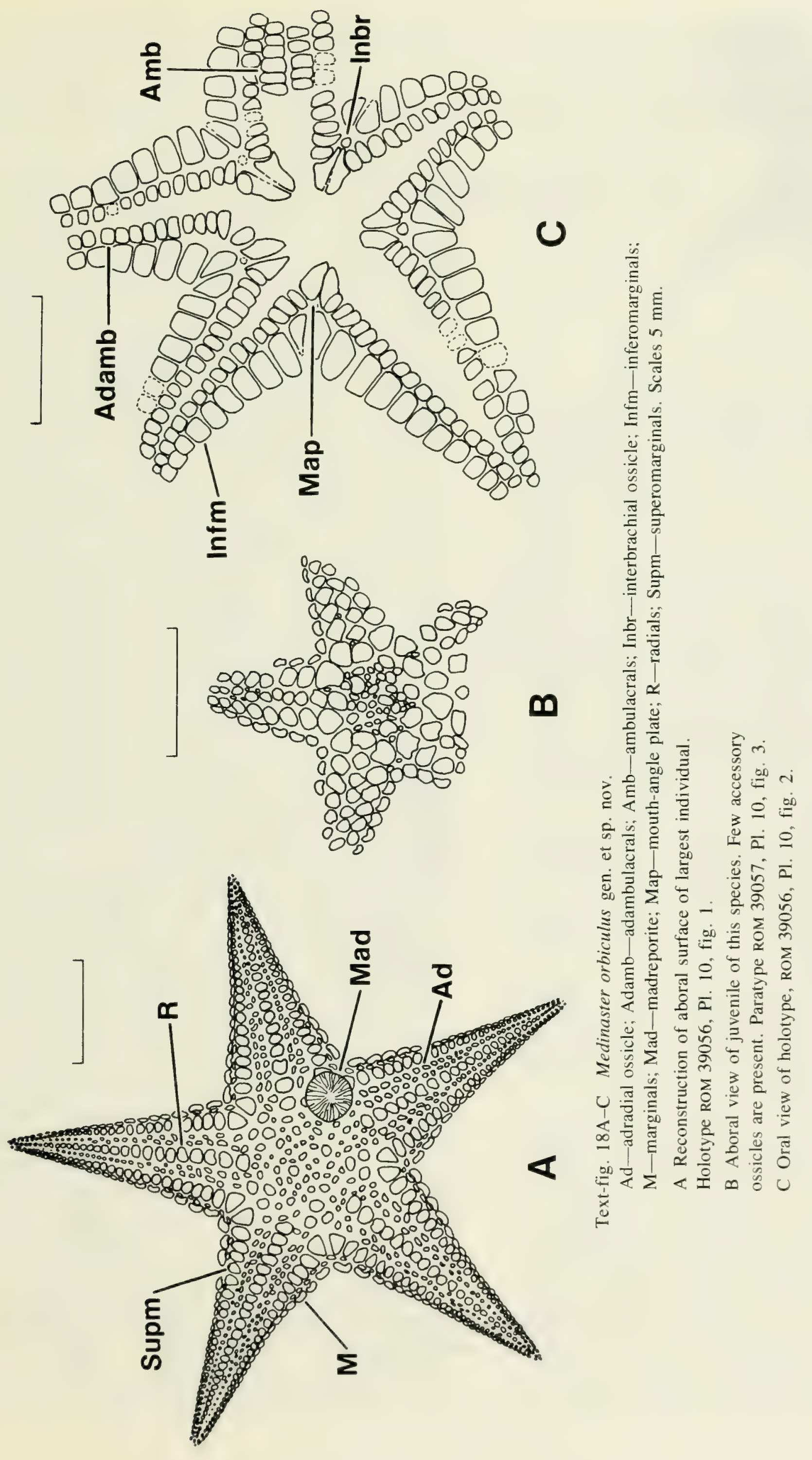


distribution at Ball's Falls. The columns of the crinoids, several an estimated $70 \mathrm{~cm}$ in length, elevated the crowns well above the substrate. By virtue of their long stems, the crinoids were at times able to survive brief periods of rapid deposition of clastics that smothered epibionts resting directly on the sea floor.

The Cabot Head Formation contains crinoids that I have interpreted to have been vagile benthos under certain conditions. This feature may also have conferred adaptive advantage (see following section).

\section{AUTECOLOGY}

\section{ATTACHMENT AND INFERRED MODE OF LIFE}

Many Palaeozoic crinoids were permanently attached to the sea floor by means of a holdfast. Holdfasts have been classified according to terminology that has varied considerably. Terms used in this discussion are those of Brett (1981b).

Holdfast morphology and substrate type are commonly correlated (Brower, 1973; Franzen, 1977; Brett and Liddell, 1978; Brett, 1981b; Lewis, 1982). Discoid holdfasts, including digitate, lobate, and multi-plated forms, are typically attached to bryozoans, brachiopods, or hardgrounds, all of which provided firm substrates. Substrate-cemented radicles typify certain crinoids that colonized hardgrounds (Brett and Liddell, 1978). Crinoids that were attached to soft substrates generally bear a radix consisting of elongate, branched radicles that penetrated into the sediment to provide firm anchorage.

The holdfasts described above were characteristic of sessile, permanently attached crinoids. Certain Palaeozoic crinoids, however, possess stems that taper almost to a point distally, and others bear lateral cirri along most of the column. These genera may have been vagile benthos under certain conditions.

Ptychocrinus medinensis and Nexocrinus delicatulus gen. et sp. nov. are common genera in the Cabot Head Formation. The columns of these crinoids taper almost to a point distally. Both species were anchored to other objects by means of a coiled dististele.

Coiling of the column round other objects may have been a common method of attachment for many pelmatozoans, but it has received little attention in literature (Kirk, 1911; Ehrenberg, 1929; Brett, 1978a, b,). Ehrenberg observed distal portions of the column of Glyptocrinus dyeri individuals (Upper Ordovician, Cincinnatian) that were wrapped round other crinoid stems. Some individuals of Ptychocrinus medinensis attached their dististele coils to the columns of conspecific crinoids (Brett, 1978b). Brett, citing hydrodynamic instability, indicated that the attachment of one Ptychocrinus individual to another was difficult to comprehend if the crinoids were vertically oriented. By implication, only the columns of recumbent- or runner-mode Ptychocrinus individuals (p. 51) would have been suitable for attachment by conspecific crinoids. I consider this restriction unlikely. An occurrence of dimerocrinitids attached to the column of an Eucalyptocrinites individual is evidence that, in life, the vertically oriented column could support secondarily attached crinoids and other invertebrates (Brett and Eckert, 1982). Additional evidence is provided by numerous examples of distal coils attached to other crinoid columns from the Upper Silurian Rochester Formation of Ontario, the Middle Devonian Ludlowville Formation of western New York State, and the Middle Devonian Hungry Hollow Formation of Ontario. Some of these coils may have been attached to stem fragments of dead pelmatozoans, but examples of ingrown coils are known that are proof of a long-term mutualistic relationship among living crinoids. In these instances, the primary column continued to increase in diameter, gradually engulfing the apparently rigid distal coil attached to it. Hydrodynamic instability or stem breakage would probably have occurred only if the secondarily attached individual grew to be much larger than its host.

Ehrenberg (1929) postulated a semi-eleutherozoic mode of life for Glyptocrinus dyeri. According to this hypothesis, periods of attachment to objects by means of a distal coil alternated with periods of an eleutherozoic habit when conditions became locally inhospitable. In this manner the crinoid could move from place to place with swimming movements of the arms and by passive drifting aided by currents, then reattach itself when conditions were favourable. Ptychocrinus and Nexocrinus individuals may have lived in a similar manner.

The attachment coils of juvenile Ptychocrinus individuals are inferred to have been prehensile. However, evidence of ankylosis and the development of cuneiform columnals indicate that the attachment coils of large individuals were rigid and incapable of being uncoiled (Brett, 1978a). This suggests that, after initial attachment, Ptychocrinus individuals were typically sessile for long periods. At the same time, the small diameter of the dististele, approximately $1 \mathrm{~mm}$ adjacent to the attachment coils, suggests that these organisms were prone to breakage of the column at this point during periods of unusually strong current activity. A recent discovery at Ball's Falls of nearly entire Ptychocrinus specimens lacking only the attachment coils is evidence of this tendency. The dististeles of these specimens are typically preserved as curved arcs, suggesting that they were highly flexible. It seems reasonable to infer that, unless buried in catastrophic fashion, these crinoids were capable of reattaching themselves to the sea floor. During the unattached phase, therefore, these crinoids may have moved from place to place by means of drifting with 


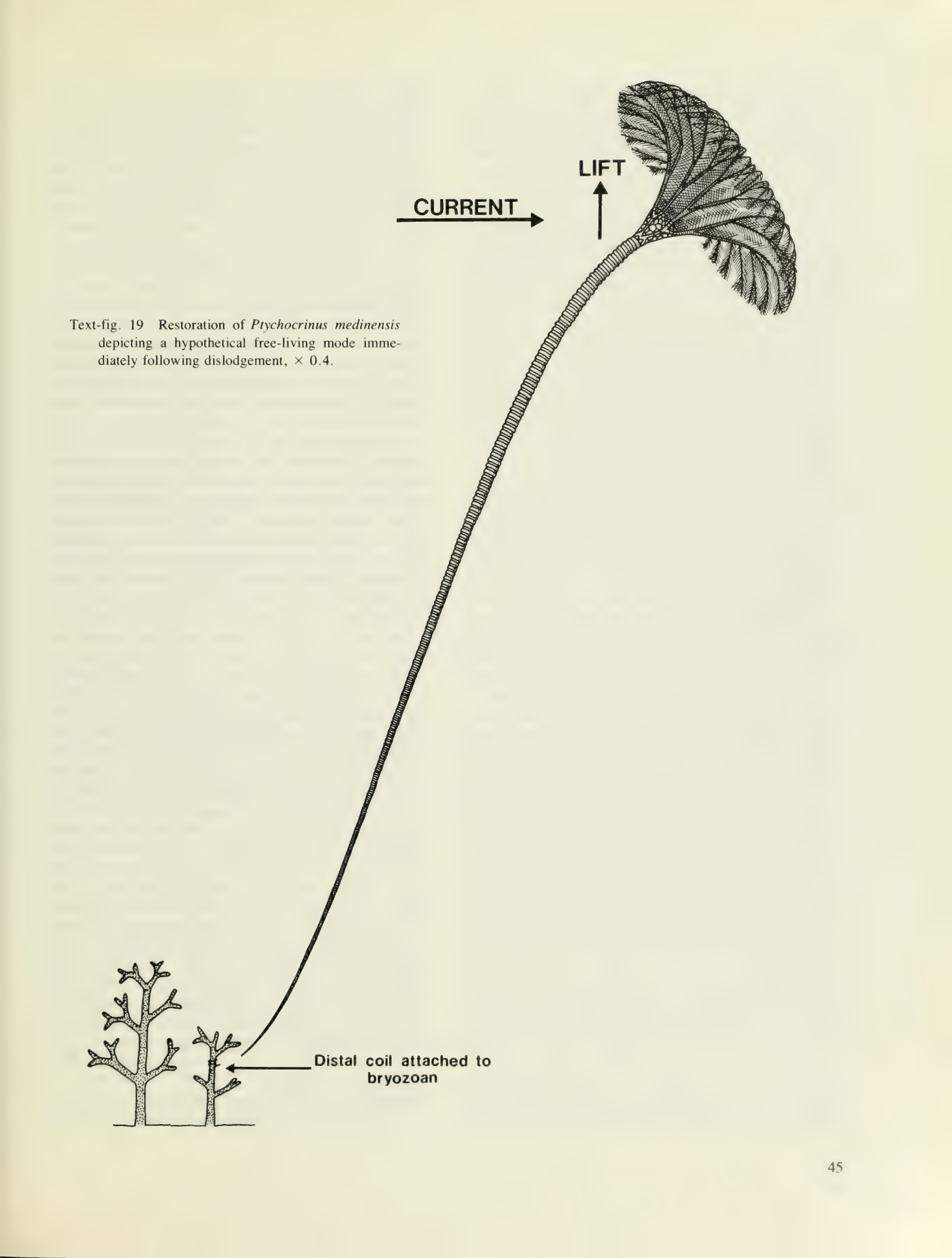


currents (Text-fig. 19). In this mode, the arms are judged to have been held in a parabolic filtration-fan configuration to take advantage even of weak currents. Orientation of the filtration fan at an angle to the current would have provided lift as well as forward motion. In this manner, the crinoid crown would have remained elevated above the substrate. Furthermore, the long column of $P$. medinensis shifted the centre of gravity of the organism to a point well below the crown. This in tum would have increased the stability of the organism while it drifted. The column is inferred to have acted as a drag or ballast to assist proper orientation.

Lift would not have been possible during periods of slack current. The stem and crown of an unattached Ptychocrinus individual would have lain on the substrate under these conditions, increasing the probability of fouling of the food grooves. Curvature of the highly flexible proxistele, however, would elevate the crown enough to reduce this danger: if at all curved, the long column, now resting on the substrate, would act as a platform so that the crown would not tip over (Kirk, 1911; Brett 1981b). This suggests that Ptychocrinus individuals, normally anchored to the sea floor, may also have been able to exist in an unattached mode. This interpretation may also be true for the Ordovician crinoid Cincinnaticrinus (Weaver, 1976).

The inferred ability of Ptychocrinus medinensis to exist in an unattached mode may have aided dispersal of this species in environments marginal to many crinoids. Most Palaeozoic crinoids had only one dispersal phase, the period when the larvae were free-living. Lineages characterized by a coiled dististele or lateral cirri, however, may have had an additional dispersal phase when currents detached individuals from the sea floor. This explanation is speculative and needs to be tested in a flume.

The abundance of Ptychocrinus and Nexocrinus in the Cabot Head Formation is probably correlated with their mode of attachment to the substrate and is attributed to chance pre-adaptation. The wide distribution of Ptychocrinus and Glyptocrinus in Ordovician platform carbonates suggests that the coiling of the dististele of ptychocrinid, glyptocrinid, dimerocrinitid, and melocrinitid lineages originated in more favourable environments and remained a persistent feature. This feature may in fact have contributed to the success and diversity of these groups.

Kylixocrinus latus gen. et sp. nov. and Macrostylocrinus jordanensis sp. nov. are also relatively common crinoids in the Cabot Head Formation. The columns of these genera are lined with whorls of cirri. Modern isocrinids and pentacrinids also have stems lined with whorls of cirri and are adapted for life on soft substrates. Rasmussen (1977) studied the autecology of these organisms. These crinoids attach themselves to sediment, organisms, or other objects on the substrate by means of grasping cirri. Individuals with short columns stand almost vertically, attached by a few verticles of cirri. Larger individuals assume a partial runner mode and are anchored by many whorls of cirri. Rasmussen postulated that, upon breaking at weak points below nodals, these crinoids drift along the bottom, swimming with their arms until they reattach themselves. Kylixocrinus latus and Macrostylocrinus jordanensis individuals may have lived in similar fashion. However, unlike many modern crinoids, Palaeozoic camerates commonly possessed unions of limited ability between the free brachials of the arms (Van Sant and Lane, 1964). Accordingly, unattached Kylixocrinus latus and Ptychocrinus medinensis individuals probably had little, if any, swimming ability. However, the densely pinnulate arms of these species could have formed a parabolic filtration fan that would have been admirably suited for passive drifting

Kylixocrinus latus and Macrostylocrinus jordanensis inhabited a prodeltaic environment. The occurrences of these two species support the theory that the separation between macrostylocrinid lineages bearing lateral cirri and macrostylocrinids without cirri may be related to substrate type, the former lineage being adapted to living on sand, silt, and clay substrate and the latter restricted to limestone and shaly limestone (Brower, 1975). It should be noted, however, that crinoids with lateral cirri are not restricted to clastic facies.

Dendrocrinus parvus is moderately common in the Cabot Head Formation. Dendrocrinus is an important Ordovician-Silurian genus that has a wide distribution in a variety of lithotopes, unlike many Palaeozoic crinoids. The success of this genus was probably correlated with its flexible modes of attachment that permitted colonization of a wide range of substrates including mud, silt, sand, and carbonates. Depending on the species, the holdfast of Dendrocrinus consists of branched radicular cirri, a distal coil, or a distal coil in combination with hirsute cirri. In this aspect Dendrocrinus contrasts markedly with many other Palaeozoic crinoids, which, in the writer's experience, tend to have a similar holdfast type within a given genus. Dendrocrinus celsus (Upper Silurian) has a holdfast with branching radicles and was probably permanently moored to the sea floor. Species that possess a distal coil ( $D$. oswegoensis, Upper Ordovician) or a distal coil in combination with fine, hairlike cirri $(D$. longidactylus, Upper Silurian) may have been colonizers of soft, shifting substrates unsuitable for many crinoids. A mat of threadlike appendages analogous to the highly branched pedicle of the Recent brachiopod Clidophora may have permitted $D$. longidactylus to colonize soft substrates (Brett, 1978b).

Crinoids with discoid or branching holdfasts are rare in the Cabot Head Formation, probably because they 
required hard substrates such as bryozoans for initial attachment. The rarity of Calceocrinus and Protaxocrinus in these strata is possibly explained by this lack of hard substrates. Cataractocrinus clementi is at present the only known crinoid with a rhizoid holdfast in the prodeltaic facies. Unfortunately the holdfasts of Dendrocrinus parvus, Homocrinus diminutus, and Pariocrinus heterodactylus could not be determined.

\section{PALAEOECOLOGY AND FUNCTIONAL MORPHOLOGY OF THE CALCEOCRINIDAE}

Disparid inadunates of the family Calceocrinidae occur sparsely in the Cabot Head Formation. Calceocrinids are among the most interesting groups of Palaeozoic crinoids from the standpoint of their morphological specialization and their adaptation to a specific mode of life (Moore, 1962; Brower, 1966, 1977). They are characterized by marked bilateral symmetry of the crown and by a specialized hinge mechanism that permitted reflexing of the crown along the column (see Springer, 1926:96 for discussion). Previous researchers have not emphasized the posterior extensions of the B- and C-ray inferradials of many calceocrinids. This arrangement enclosed the basal circlet within a triangular notch when the hinge was in the closed position, protecting the muscles and ligaments of the hinge mechanism. This feature is well developed in Diaphorocrinus pleniramulus gen. et sp. nov. and in certain species of Calceocrinus.

\section{MODES OF LIFE}

Ringueberg (1889), Jaekel (1918), Springer (1926), Brower (1966, 1977), Kesling and Sigler (1969), Breimer and Webster (1975), Brett (1981a), and others have contributed to an understanding of the functional morphology of calceocrinids. Three basic modes of life have been proposed. These are here informally termed the "drooper", "runner", and "runner-kite" hypotheses.

The drooper hypothesis assumes that the calceocrinid crown hung in pendant fashion from a subvertical stem. The hinge mechanism swung the crown away from the stem for feeding. The closed or recumbent position, with the crown reflexed along the stem, was adopted during resting and protective modes.

Jaekel (1918) postulated a runner or recumbent mode of life in which the stem rested on the substrate and the crown, directed downcurrent, was elevated by the hinge mechanism for feeding. This hypothesis was accepted by the majority of authors, although direct evidence was lacking. In later years, discoveries have substantiated Jackel's interpretation.

The taphonomy of an occurrence of Cremacrinus arctus, (Sardeson, 1928; Brower, 1966) provides indirect evidence supporting a recumbent mode of life for this calceocrinid. Individuals preserved with arms directed upwards and calyces partially buried in the sediment are inferred to have been buried in living position. However, the hinges of these specimens are closed, while the runner hypothesis specifies an open hinge when the crown is directed upwards. Furthermore, the stems of these individuals are recurved. Studies by Brett (1978b) and the writer suggest that these features can, in fact, be reconciled with a recumbent habit (p. 48).

The discovery of complete calceocrinids with a column appreciably shorter than the crown negated the drooper hypothesis for certain species (Brower, 1966). Brower noted that when an individual was in a drooper attitude the food grooves would be fouled with sediment since the crown would drag on the substrate. This comment is not applicable to most calceocrinids because they possess a stem appreciably longer than the height of the crown.

Brower (1977) reported abnormalities in the hinge structure of Paracremacrinus and suggested that warped or bent hinges resulted from abutment against rigid objects such as bryozoan zoaria resting on the substrate. The writer believes a drooper mode of life would not produce similar abnormalities.

The holdfasts of calceocrinids provide additional evidence that supports the runner hypothesis. Holdfasts of typical echinoderms with subvertical stems tend to have subhorizontal stem facets unless they are attached to sloping surfaces such as hardgrounds. The stem facets of calceocrinid holdfasts, however, are typically steeply angled to the substrate and are more consistent with a runner stem than with one having a vertical orientation $(\mathrm{Pl}$. 7, figs. 1, 2).

Breimer and Webster (1975) suggested that runnermode calceocrinids may have been able to derive lift from currents in a manner analagous to that of a kite on a string. Heavy construction of the crown and stem of most forms makes this improbable (Brett, 1981a). Lift would be minimal in most instances and would be unlikely to confer adaptive advantage. Currents sufficient to provide lift would probably be associated with resuspended sediment and with the possibility of stem breakage. Under such conditions, calceocrinids would probably have adopted a recumbent position with closed hinge to avoid possible dislodgement or fouling of the ambulacra.

The majority of calceocrinids probably lived in a recumbent or runner position with the stem resting on the substrate. The low feeding niche thus occupied removed calceocrinids from competition with echinoderms that had subvertical stems, possibly accounting for the success and diversity of calceocrinids (Brower, 1966).

\section{HOLDFASTS}

Calceocrinid holdfasts have been reported by Springer (1926), Jaekel (1918), Brower (1966, 1977), and Brett 
(1981a). The holdfasts of several specimens are known, including those of Cremacrinus sp. and Paracremacrinus laticardinalis (Middle Ordovician), Calceocrinus chrysalis (Upper Silurian), and Deltacrinus sp. (Middle Devonian). Hard objects were generally used for attachment, and bryozoans were especially favoured.

The inferred mode of life of calceocrinids suggests that most, if not all, individuals were permanently attached to the sea floor. Calceocrinids with lateral cirri or distally coiled columns, which could be indicative of a free-living existence, are unknown. Modern stemless comatulid crinoids have limited swimming ability, but the stout, poorly flexible, apinnulate arms of calceocrinids would have been ill-adapted for swimming movements or for taking advantage of currents for drifting purposes.

Brett offered an explanation for permanent attachment of calceocrinids. He noted that the opening of the hinge mechanism would have tended to elevate the column, impeding efficient operation of the hinge. Distal anchoring of the column remedied this situation, and the anchoring appears to have been further augmented in some species by the development of long, heavy stems that may have acted as ballast (Brett, 1981a). The recurved stems of Cremacrinus arctus mentioned previously may have resulted from the closing of the hinge mechanism in individuals that had been detached from their holdfasts by strong currents. This interpretation of the functional morphology of calceocrinids suggests that the semieleutherozoic or pelagic mode of life postulated by Schmidt (1934) for the Devonian calceocrinid Senariocrinus is improbable.

\section{CROWN AND COLUMN STRUCTURE}

Brower (1966) suggested that the evolutionary trend towards perfect bilateral symmetery of the calceocrinid crown through the elimination of the B-ray arm removed the sideways torque due to gravity that could have upset the animal from its normal living position. The writer hypothesizes that sinuous or crenulate articular surfaces of the columnals of calceocrinids such as Calceocrinus pustulosus and Diaphorocrinus pleniramulus prevented the sideways torque induced by currents by increasing the rigidity of the column.

Springer (1926) and Kesling and Sigler (1969) observed that many calceocrinids possess a posterior groove along the aboral side of the anal tube that permitted the crown to be closely opposed with the column. They postulated that this feature served to make these crinoids as compact and as inconspicuous as possible. The writer regards this hypothesis as unlikely since a minimal reduction in height would have resulted. Hydrodynamic factors were probably more significant. When the calceocrinid was in the closed position, currents would have tended to twist the crown away from the stem axis, particularly if the crown was facing upcurrent. A posterior groove would have provided a splined arrangement to resist these forces.

Jaekel (1918), Brower and Veinus (1978), Kesling and Sigler (1969), and Breimer and Webster (1960) discussed the feeding posture of calceocrinids. The typical calceocrinid is envisioned lying recumbent on the sea floor in life, with its column and crown directed downcurrent in a weathervane fashion. When the calceocrinid was feeding, the crown was elevated by the hinge mechanism so as to be nearly at right angles to the column. A filtration fan was formed with the oral sides of the arms facing upcurrent. This feeding posture appears plausible for many calceocrinids. In the writer's opinion, however, it is doubtful that the column functioned in a weathervane fashion except perhaps in strong, unimodal flow regimes, and these appear to be atypical of the environments in which most calceocrinids lived (Brower and Veinus, 1978). Currentinduced rotation about an arc, with the holdfast at the apex facing upcurrent, would have created torsional stress in the dististele. The calceocrinid column was ill-adapted for such forces. The writer favours the hypothesis of Brett (1981a) in which the column and holdfast acted together mainly as a lever to permit efficient operation of the hinge.

The Calceocrinidae exhibit a wide variation in the structure of the crown and axil arms. This in turn suggests that calceocrinids were adapted to a variety of environmental niches and that they used a variety of feeding strategies (Brett, 1981a). In many fossil crinoids, vertically held collecting-bowl configurations increased feeding time during periods of slack current (Haugh, 1978). Many calceocrinids may also have been able to feed in a rheophobic manner. The structure of the radial facets of Calceocrinus, for example, permitted the axil arms to be oriented at nearly right angles to the calyx. In this position, the A- and D-ray arms would have been nearly parallel to the substrate, and their ambulacra directed upwards. This orientation would have facilitated capture of food particles that drifted downwards by gravitational settling. It seems unlikely that calceocrinids with sparsely branched arms, such as the Upper Silurian species Calceocrinus chrysalis, could have formed an effective filtration fan or collecting bowl. Conversely, extensive development of ramules in the axil arms of Chirocrinus and Halysiocrinus may have permitted these crinoids to form a filtration fan or perhaps a vertically held collecting bowl adapted for capture of fine food particles, as postulated by Ausich (1980) for Mississippian cinoids.

Calceocrinids were rare in environments characterized by a high rate of clastic influx. The Cabot Head Formation at Ball's Falls is representative of this type of environment. The writer has collected only five calceocrinids out of a total of more than 250 crinoids obtained at this locality. Calceocrinids were more common in offshore areas where depositional rates were slower and more 
uniform. Brett (1981a) observed a similar distribution of calceocrinids in the Upper Silurian Rochester Formation in New York State.

\section{SYNECOLOGY}

\section{POPULATION STRUCTURE OF CRINOID COMMUNITIES}

Six localized occurrences of crinoids have been discovered at Ball's Falls. These occurrences represent stands (sensu Lane, 1973) that occupied a roughly circular area on the sea floor ranging in size from $0.1 \mathrm{~m}^{2}$ to more than $12 \mathrm{~m}^{2}$. A typical stand contained fewer than 20 crinoids while the largest had more than 200 individuals.

Brower (1973) classified crinoid stands according to their population density. Occurrences with fewer than 200 individuals per square metre were classified as low-density stands, and the remainder as high-density stands. Accordingly, four occurrences at Ball's Falls represent lowdensity stands, with 50 to 150 individuals per square metre. One stand was represented by a monotypic assemblage of Nexocrinus delicatulus; in the remainder Dendrocrinus parvus, Macrostylocrinus jordanensis, or Kylixocrinus latus predominated. The Dendrocrinus occurrence yielded seven specimens of $D$. parvus and several poorly preserved specimens of an indeterminate camerate. The Macrostylocrinus occurrence yielded nine specimens of $M$. jordanensis, three specimens of Calceocrinus tridactylus, one specimen of Protaxocrinus cataractensis, and two specimens of an indeterminate camerate. The Kylixocrinus occurrence yielded 16 specimens of $K$. latus, 10 specimens of Cataractocrinus clementi, and one specimen each of Dendrocrinus parvus and Calceocrinus sp. In each of these low-density occurrences a single crinoid species predominated. A maximum of four crinoid species was observed in low-density stands.

Two occurrences represented high-density stands containing 250 to 300 individuals per square metre. One of these was a monotypic assemblage of Nexocrinus delicatulus; the other represented an unusually large stand of Ptychocrinus. More than 200 specimens of $P$. medinensis were recovered from a siltstone lens $4 \mathrm{~cm}$ in thickness. This occurrence also yielded 11 specimens of Pariocrinus heterodactylus and three specimens of Protaxocrinus cataractenesis. The vertical nature of the exposure hampered complete excavation of this stand. The maximum density of crinoids near the centre of this stand was 300 individuals per square metre. A maximum of four crinoid species was observed in high-density stands.

Brower (1973) noted that high-density crinoid stands of young assemblages and of adult assemblages tended to be mutually exclusive. He based these observations on material collected from the Upper Ordovician Girardeau Limestone of Missouri and Illinois. Young and adults were arbitrarily defined by aboral-cup height, such that the average size of juveniles was one-third that of adults. Application of these criteria to the occurrences in the Cabot Head Formation gives evidence that supports Brower's hypothesis. Size-frequency analysis of the Ptychocrinus stand reveals a unimodal distribution (Textfig. 20). The majority of individuals fall within a 9 to $12 \mathrm{~mm}$ size range; specimens less than $5 \mathrm{~mm}$ in size are absent. Comparison with other occurrences of $P$. medinensis suggests that this is an adult assemblage. The single high-density stand of Nexocrinus may also represent an adult assemblage.

The size-frequency distributions in the low-density stands have not been studied in detail owing to the small size of populations involved. These stands appear to have been composed largely of adults.

Brower (1973) suggested that biochemical secretion was responsible for the absence of juveniles in highdensity stands of adult crinoids. The supposed secretions increased survivorship potential by repelling larvae away from stands where food resources were being fully utilized. Brower noted, however, that adult crinoid assemblages could have been augmented by successive spatfalls, yet still produce unimodal size distribution owing to blurring caused by slow-fast-slow growth-time vectors. Presumably, augmentation would occur primarily in stands that could accommodate a higher population density.

Many marine invertebrates are known to be affected by the presence or absence of conspecific individuals (Knight-Jones, 1953; Johnson, 1964; Boolootian, 1966; Crisp and Meadows, 1967; Barnes, 1974). This coexistence results in efficient utilization of trophic resources and aids reproduction. Many modern crinoids are notably gregarious (Macurda, 1975; Macurda and Meyer, 1977). Conspecific clusters of crinoids observed in the Cabot Head Formation and similar occurrences observed by Watkins and Hurst (1977) indicate that Palaeozoic crinoids were also gregarious. Clustering of crinoids confers adaptive advantage by providing viable breeding populations (Brower, 1973). This would have been advantageous in the marginal prodeltaic regime represented by the Cabot Head Formation at Ball's Falls.

\section{ASSOCIATED FAUNA}

A sparse, nonechinoderm fauna is associated with most occurrences of crinoids in the Cabot Head Formation at Ball's Falls. Sessile, epifaunal suspension feeders predominate. They are typified by the brachiopods Resserella and Fardenia?, orbiculoids, rhynochonellids, and the bryozoan Helopora fragilis. The gastropods Hormotoma and Lophospira are also common.

Burrows filled with sand in a siltstone lens containing Ptychocrinus indicate that infaunal deposit feeders were also present. However, the crinoid remains themselves are 
rarely bioturbated, perhaps owing to rapid burial by anoxic sediment (Brett, 1978a). Asteroids associated with the Ball's Falls and other crinoid stands were probably scavengers. Asteroid-crinoid assemblages are not uncommon at several localities in Ontario. The writer has observed the co-occurrence of these organisms in the Middle Ordovician Bobcaygeon Formation, the Upper Silurian Rochester Formation, and the Middle Devonian Arkona Formation.

Occurrences of Macrostylocrinus and Nexocrinus at Ball's Falls also yielded poorly preserved orthoconic nautiloids. Brett (1978a) reported similar cephalopods occurring with Ptychocrinus. A stand of Dendrocrinus from the Rochester Formation near St. Catharines also yielded a large nautiloid (ROM 35821). Although these examples may have resulted from chance entanglements of empty, drifting shells with stands of crinoids, the rarity of nautiloids in these strata argues against chance association. Rather, once lodged on the sea floor, these shells may have provided suitable microhabitats that were colonized by echinoderms. Mr. Terry McDonald, of Islington, Ontario, collected a large, coiled cephalopod from the Middle Devonian Arkona Formation near Thedford, Ontario, that bears several crinoid holdfasts. In the other examples cited, however, direct attachment of crinoids to nautiloids was not observed.

Gastropods are commonly attached to the tegmen of certain Palaeozoic crinoids. The molluscs were coprophagous commensals in these instances (see Bowsher, 1955, for summary). The gastropod Naticonema sp. is attached to the tegmen of many Ptychocrinus individuals at the Ball's Falls locality (PI. 3, fig. 1). This is the first reported

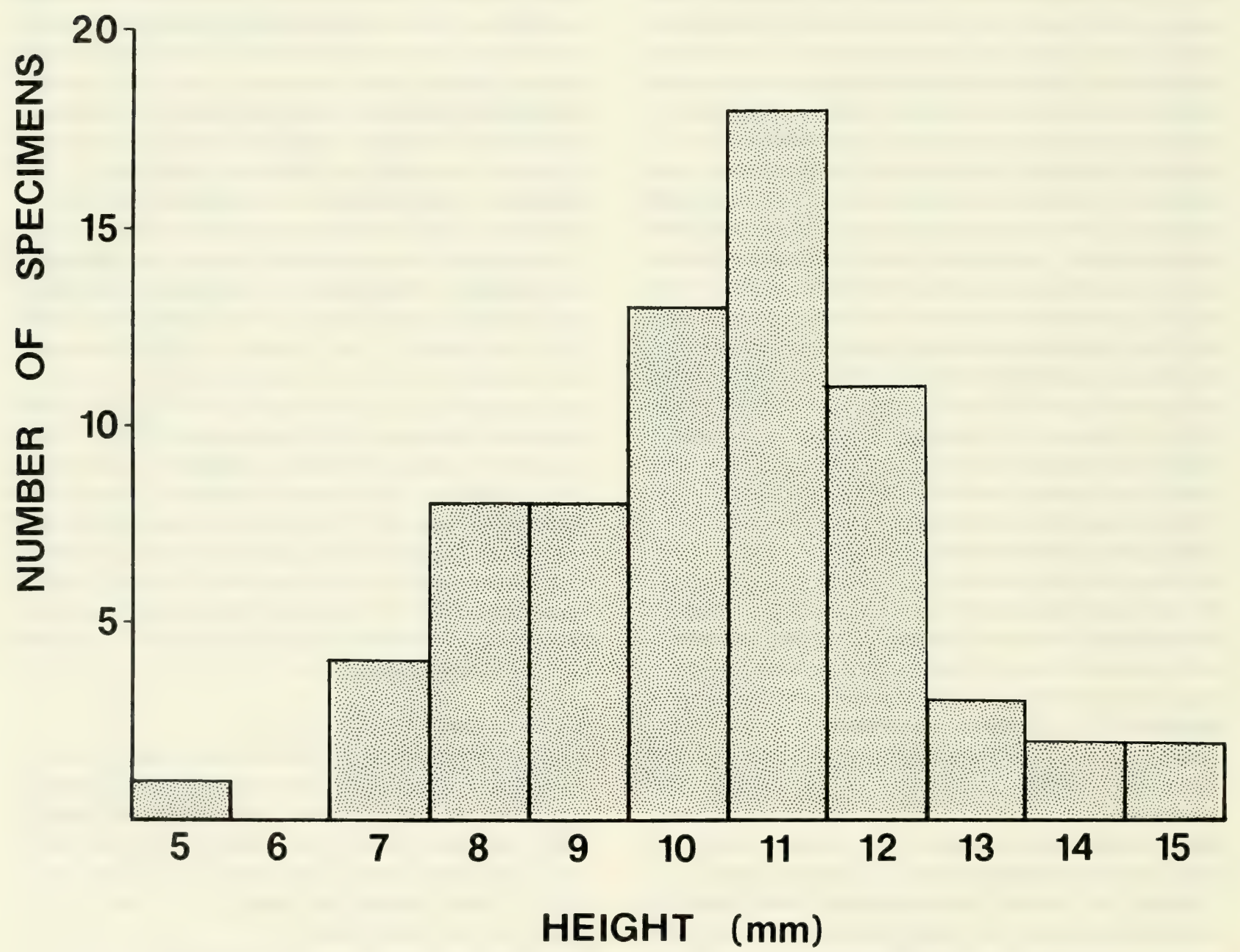

Text-fig. 20 Size-frequency histogram of 70 specimens of Ptychocrinus medinensis representing part of a large stand $3.0 \mathrm{~m}$ above base of Cabot Head Formation at Ball's Falls on Twenty Mile Creek near Jordan, Ontario. Size refers to height of calyx measured from base of infrabasals to distal tip of first axillary. 
occurrence of crinoids with commensal gastropods from the Lower Silurian. Identical gastropods occurred with, but were not attached to, crinoids in a stand of Ptychocrinus from the Niagara Gorge (Brett, 1978a) and indeterminate camerates at Ball's Falls. These gastropods may have been either scavengers or commensals that were detached from their hosts.

The size of the gastropod closely matches that of the tegmen of its host in these examples. This feature is also well illustrated by the growth series of the Middle Devonian host crinoid Athroacantha and its attached gastropod Platyceras. These associations were of longterm duration, as indicated by the salients and re-entrants of the gastropod aperture that fit those of the tegmen (Bowsher, 1955). The large size attained by many of these crinoids indicates that the relationship was not deleterious to the host.

\section{NICHE PARTITIONING}

Niche partitioning in Palaeozoic crinoid communities resulted in efficient utilization of trophic resources, allowing coexistence of varied taxa (Lane, 1972, 1973; Watkins and Hurst, 1977; Ausich, 1980). Food resources were probably subdivided among these organisms according to their relative heights above the substrate. In the crinoid communities at Ball's Falls, the lowest level was sparsely inhabited by brachiopods, rugose corals, and calceocrinids that rested on the sea floor. Certain crinoids other than calceocrinids may also have been able to adopt a recumbent posture, as postulated by Ehrenberg (1929) for Glyptocrinus dyeri. Brett (1978a) presented evidence of this habit for Ptychocrinus medinensis. The U-shaped curvature of the proxistele of certain individuals, which was produced by wedge-shaped columnals, suggested to Brett than much of the column rested upon the substrate and that only the proximal portion, including the crown, was elevated. Similar curvatures of the stem have been observed in Nexocrinus (P1. 3, fig. 5) and Ptychocrinus individuals at Ball's Falls. A recumbent mode of life has also been postulated for Nevadacrinus (Lane and Webster, 1966), Protaxocrinus (Brower, 1973), and Calycocrinus (Moore and Strimple, 1973). This adaptation permitted these organisms to exploit a niche not utilized by conventionally oriented crinoids. At Ball's Falls, however, recumbent camerates and calceocrinids are rare, indicating that any advantages that these organisms gained by this posture were outweighed by the increased danger of fouling or of catastrophic burial in this setting.

A second tier consisting of ramose and cryptostome bryozoans, particularly Helopora, fed at a level estimated to be $10 \mathrm{~cm}$ above the sea floor or lower. This tier is typically poorly developed. The palaeoenvironment represented by the Cabot Head Formation at Ball's Falls was unsuited for extensive growth of bryozoans (p. 42).
The third and highest tier, estimated to be 8 to $70 \mathrm{~cm}$ above the sea floor, was inhabited by various species of crinoids. The majority of these species appear to have fed at a level 10 to $20 \mathrm{~cm}$ above the sea floor. Ptychocrinus individuals fed at the highest level, estimated to be 50 to perhaps $70 \mathrm{~cm}$ above the substrate.

Taxonomic composition determined the number of tiers and their heights within a given stand. Little overlap is present in tiers of various genera, and thus interspecific competition for food was reduced (Ausich, 1980). The Kylixocrinus occurrence may be cited as an example. In this stand, Calceocrinus fed just above the substrate, Kylixocrinus at a level of 8 to $12 \mathrm{~cm}$ (estimated), and Cataractocrinus at a level of 15 to $20 \mathrm{~cm}$ (estimated) above the sea floor. Variation in stem length also reduced intraspecific competition in monotypic stands or in those where a single species predominated, so that not all individuals fed at the same level. This permitted higher population densities to be accommodated, which in turn created a community baffle that aided all members and allowed feeding specialization (Haugh, 1979).

Certain crinoids and brachiopods normally restricted to lower levels may have been able to feed at a higher level by attaching themselves to other crinoid columns, modifying trophic structure slightly.

Second-order niche differentiation further reduced interspecific competition and was effected by food-size selection and feeding posture (Ausich, 1980, 1983). The size of food particles captured by camerates was, in part, controlled by pinnule spacing of the arms and width of the food grooves. The grooved ventral surfaces of the arms of many inadunates are notably wider than those of most camerates and may have permitted inadunates to capture larger food particles. This may be an explanation for occurrences of camerates and inadunates in the same stand. Such associations are common in the Palaeozoic; co-occurrence of Kylixocrinus and Cataractocrinus, and of Ptychocrinus and Pariocrinus are examples in this study. This hypothesis must be considered speculative because, in life, many organs occupied the food groove on the arms (Haugh, pers. comm., 1980). It is therefore difficult to determine with certainty the actual widths of the food grooves on fossil crinoids.

The pinnule spacing and the widths of the ambulacra of Cabot Head camerates are similar. This may indicate that these genera competed for the same food resources and may explain why a single species commonly predominated in high-density stands of Palaeozoic crinoids. Monotypic assemblages of Nexocrinus and stands of Ptychocrinus are examples of such predomination from the Cabot Head Formation.

The food-gathering ratio, a ratio of total ambulacral length to cup volume, has been used in an attempt to quantify palaeoecologic analysis of fossil crinoids 
(Brower, 1973; Brett, 1981a). Haugh (pers. comm., 1980) states that these kinds of calculations are of limited usefulness because metabolic rate, duration of feeding, periodicity of feeding, nutritional value of the food, and other factors are impossible to determine. The writer is in agreement with this criticism. As an example, the food-gathering ratios of inadunates are typically one or two orders of magnitude less than those of camerates. This would imply that inadunates were less efficient feeders than camerates. The success and diversity of inadunates in the Palaeozoic, however, suggests that they were indeed efficient feeders

The camerate crinoids of the Cabot Head Formation were probably rheophilic suspension feeders, by analogy with modern stalked crinoids (Breimer, 1969; Macurda and Meyer, 1974, 1977). The densely pinnulate arms and the proximal flexibility of the column of fossil forms suggest that a horizontally directed, parabolic filtration fan was used to permit capture of phytoplankton and zooplankton by means of a mucus net. Evidence of current activity during deposition of the Cabot Head Formation has been previously documented (p. 8). An occurrence of Ptychocrinus medinensis in a channel-fill sandstone deposit is good evidence of a rheophilic habit for this species (Brett, 1978a). The outspread arms and inverted orientation of the crowns of Kylixocrinus latus suggest that these individuals were buried while feeding in a rheophilic manner (p. 10). The feeding postures of these camerates may have been augmented by vertically held collectingbowl configurations during periods of slack current (Haugh, 1978).

The thecal pore-pinnule complex of many Mississippian camerates may have acted as parabolic and linear antennae that determined the direction and intensity of the current and arm postures (Haugh, 1975, 1978). Silurian crinoids probably possessed analagous mechanisms. Haugh postulated that the arms were infolded over the tegmen in a teardrop-shaped survival configuration to prevent stem breakage or dislodgment of the organism during periods of potentially dangerous current activity. At Ball's Falls the occurrence of Ptychocrinus and Macrostylocrinus individuals preserved as crowns indicates that this adaptation was not always successful. These individuals were apparently separated from their columns by strong currents. In the Kylixocrinus occurrence, a sudden current surge carrying large quantities of suspended sediment overwhelmed the crinoids before the arms could be retracted. In contrast, Harrington and Heaslip (1978) stated that the occurrence of Decadocrinus and Acanthocrinus individuals preserved in an inverted orientation indicated only very slight water agitation.

Traditionally, fossil crinoids with unbranched, apinnulate, or nonramulate arms have been regarded as rheophobes or current avoiders (Lane and Breimer, 1974;
Meyer and Lane, 1976). They were thought to have been fed by the gravitational settling of particulate food on a vertically held collecting bowl, and to have effected capture of this food by the use of tube feet, mucous strands, and cilia. However, occurrence of the nonpinnulate inadunate Parisocrinus mulletensis in an Ordovician channel-fill deposit is indicative of a rheophilic habit for this species (Haugh, 1979). Ausich (1980) considers most inadunates to have been rheophiles. Many Palaeozoic inadunates, particularly Ordovician forms, occur in calcarenites and other clastics indicative of current activity. At Ball's Falls probably only the delicate Homocrinus diminutus was a true rheophobe, inhabiting locally sheltered areas. Cataractocrinus may also have been a rheophobe, but the occurrence of Kylixocrinus in the same stand suggests that Cataractocrinus was a low-energy rheophile.

Physicochemical parameters relating to substrate, currents, sedimentation, and Eh probably exercised a high degree of control over crinoid communities at Ball's Falls. These communities were short-lived owing to catastrophic burial. Instability of the environment is reflected in the simple trophic structure and niche partitioning of these communities. In comparison, a high degree of environmental stability is reflected in the diverse faunas and complex trophic structure of Mississippian benthic communities (Ausich et al., 1979; Ausich, 1980).

In summary, Llandovery crinoid communities at Ball's Falls show evidence of niche partitioning. Intraspecific and interspecific variation in column length permitted crinoids to feed at different levels, optimizing foodgathering efficiency and increasing population density of these organisms. Utilization of food particles of different sizes may have enhanced coexistence of camerates and inadunates. A variety of feeding postures was used.

\section{PALAEOECOLOGIC SIGNIFICANCE OF CRINOIDS}

The importance of crinoids as colonizing organisms and substrate modifiers has not been adequately stressed in literature. Crinoids were commonly among the first organisms to colonize substrates (Halleck, 1973; Brett and Liddell, 1978). Firm substrates provided by the ossicles of living crinoids were in turn commonly colonized by other organisms. Auloporid corals, bryozoans, brachiopods, and edrioasteriods epizoic on crinoids are examples of a facultative response to an appropriate substrate by nonsymbiotic organisms (Franzén, 1974; Brett, 1978b). The writer observed orbiculoid brachiopods attached to foliate bryozoans in the Cabot Head Formation at Stoney Creek. Similar brachiopods were noted in the large Ptychocrinus stand at Ball's Falls. Orbiculoids are otherwise extremely rare in the Cabot Head Formation. 
The association of crinoids and orbiculoids suggests that, in life, the brachiopods were attached to the columns of the crinoids. An example of this kind is present in the Craig Clement Collection, now deposited in the Royal Ontario Museum. Numerous specimens of small, articulate brachiopods are attached to the column of a Gilbertsocrinus spinigerus individual from the Ludlowville Formation of Middle Devonian age in western New York State (ROM 36069).

Crinoids also served as important hosts for serpulids, cornulitids, myzostomes, and boring epizoans; the last group includes acrothoracian barnacles, bryozoans, sponges, and Phosphannulus-producing organisms (Warn, 1974; Hantzchel, 1975; Welch, 1976). Crinoid ossicles may also contain pits produced by indeterminate organisms (Brett, 1978c). However, pitting or instances of parasitization were not observed in this study. The attachment of coprophagous gastropods to crinoids is well documented here (PI. 3, fig. 1).

The ability of crinoids to add to and modify the substrate is an important characteristic of these organisms. Hundreds or even thousands of ossicles are contributed to the sea floor upon the death and disarticulation of each individual. Each ossicle is a potential substrate for other organisms. Scattered ossicles are commonly associated with crinoid occurrences at Ball's Falls. This scattered material represents the debris of individuals that died before the final burial event. The nonechinoderm faunas of the Cabot Head Formation are typically more abundant and diverse when associated with crinoid stands. This suggests that crinoid debris provided a suitable, firm substrate for nonechinoderm organisms when conditions were otherwise unfavourable.

The potential of crinoids to add to and modify the substrate was realized under conditions of slow, uniform rates of sedimentation. The Arkona Formation of Middle Devonian age in Ontario contains crinoidal carbonate lenses that appear to have been produced by the growth and death of generations of crinoids in small, densely populated stands. These stands were clearly longer lived than those in the Cabot Formation because rapid burial events had been less frequent. The crinoidal lenses in the Arkona Formation are thicker and more extensive, and the associated nonechinoderm faunas are more diverse. In ideal environments lenses coalesced to form thick deposits of crinoidal limestone, such as in the Silurian Amabel and Lockport formations of Ontario and in widespread Mississippian carbonates of the Midwest of the United States.

\section{Ordovician-Silurian Pelmatozoan Evolution}

Transgressive-regressive events exercised control over the diversity and abundance of marine invertebrates during the Palaeozoic (Moore, 1950, 1952; Valentine, 1969, 1971; Eldridge, 1974; Boucot, 1975; Sheehan, 1973, 1975; Tipper, 1975; Johnson and Campbell, 1980). Favourable intervals coincided with widespread epicontinental transgression and deposition of platform carbonates. Ordovician platform carbonates of Caradocian-Ashgillian age contain abundant and diverse echinoderm faunas. Examples include the Bobcaygeon Formation of Ontario, the Platteville Group of Wisconsin and Illinois, the Benbolt Formation of Virginia and Tennessee, and the Bromide Formation of Oklahoma.

Widespread extinction, decrease in diversity, and reduction of the standing crop of marine invertebrates typically occurred during regressive periods. These periods in turn are correlated with decreases in environmental stability and resource availability, and simplification of trophic structure (Paine, 1966; Levinton, 1972; Wilbur et al., 1974). A decrease in abundance and diversity of crinoids during the Late Ordovician coincided with a regressive phase. Glaciation centred in North Africa and South America initiated glacio-eustatic drawdown at this time (Berry and Boucot, 1973; Boucot, 1975; Dennison, 1976). Widespread unconformities at the
Ordovician-Silurian boundary indicate that a significant drop in sea level occurred. The amount of drawdown is impossible to determine. Newell and Bloom (1970) indicated that the sea level may have been lowered by $100 \mathrm{~m}$ during Pleistocene glaciation. Withdrawal of the epeiric seas from shelf areas precipitated a time of crisis for marine invertebrates near the close of the Ordovician (Sheehan, 1973, 1975; Tipper, 1975).

Extinction of crinoids near the close of the Ordovician is reflected in the low diversity of Early and Middle Llandovery echinoderm communities. Accelerated diversification of suspension-feeding echinoderm groups did not occur until the Late Llandovery when benthic communities were achieving a degree of stability on the widespread, newly created carbonate platforms (Witzke et al., 1979).

The Silurian crinoids of North America were largely derived from Ordovician genera endemic to North America (Witzke and Strimple, 1981). With the possible exception of Kylixocrinus latus, crinoids in the Cabot Head Formation appear to have been derived from North American species. The Early Silurian assemblage in the Cabot Head Formation has a close affinity with the Upper Ordovician assemblage of crinoids in the Girardeau Limestone in Missouri and Illinois. The genera Ptycho- 
crinus, Macrostylocrinus, Dendrocrinus, and Protaxocrinus are common to both formations. Ptychocrinus medinensis is very similar to the Girardeau species $P$. splendens. The Girardeau Limestone, however, has few inadunates; Pariocrinus, Cataractocrinus, and Homocrinus could not have been derived from the Girardeau fauna. They may have originated instead from as yet unknown Upper Ordovician crinoids.

Many of the crinoids that survived the OrdovicianSilurian transition probably represent relatively unspecialized eurytopic genera that could adapt to a wide range of conditions. The Girardeau genera Ptychocrinus, Dendrocrinus, and Macrostylocrinus are judged to be eurytopic crinoids that survived into the Silurian. These genera are found in a wide range of lithotopes including shale, sandstone, limestone, and argillaceous limestone.

Berry and Boucot (1970) noted that the Silurian strata of North America tend to occur in concentric zones. Dolomites predominate towards the centre of the craton. They in turn are ringed by limestones. Clastics are most abundant towards the continental margins. The preserved lineages of most Silurian crinoids are found only in carbonate deposits of the continental interior (Witzke and Strimple, 1981). The fauna of the Hopkinton Dolomite, studied by Witzke and Strimple, was adapted to a platform regime characterized by deposition of carbonates. Conversely, the crinoids of the Cabot Head Formation at Ball's Falls were adapted to a deltaic milieu. Other deltaic communities of Llandovery age were probably similar but remain undiscovered.
The crinoid fauna of the Hopkinton Dolomite is more abundant and diverse than that of the Cabot Head Formation. The differences between these two assemblages are striking. The eurytopic genus Macrostylocrinus appears to be the only echinoderm common to both occurrences. The Hopkinton Dolomite has more genera of camerates while the Cabot Head Formation has a greater diversity of inadunates. Devonian inadunates are also more abundant in clastics than in carbonates and appear to have been more tolerant of turbid water (Lane, 1978). The Cabot Head crinoids are typically smaller than those of the Hopkinton Dolomite. Sparse assemblages of crinoids adapted to soft substrates (Brower, 1975; Watkins and Hurst, 1977) also typically possessed small individuals. Variations in diversity, abundance, and size of crinoids emphasize the marked differences between level-bottom communities on carbonates and deltaic communities on clastics. These two faunal associations probably evolved into communities that remained restricted in an ecological sense (Haugh, pers. comm., 1980). The fauna described in this study is also probably transitional to later, as yet unknown, deltaic communities.

The peculiar structure of the arms of Diaphorocrinus pleniramulus, the variation in number of primibrachials in Protaxocrinus cataractensis, and the abnormal structure of the arms in a specimen of Calceocrinus tridactylus are unusual features. It is hypothesized that these characteristics were the products of random genetic drift, of mutations, or of founder effects associated with small populations (Dobzhansky et al., 1977).

\section{Summary}

A new Early Llandovery crinoid and stelleroid fauna has been discovered in the Lower Silurian Cabot Head Formation in the Niagara Peninsula in southern Ontario, Canada. Five new genera of crinoids (Kylixocrinus, Nexocrinus, Diaphorocrinus, Cataractocrinus, Pariocrinus) and ten new species (Kylixocrinus latus, Macrostylocrinus jordanensis, Nexocrinus delicatulus, Calceocrinus tridactylus, Diaphorocrinus pleniramulus, Cataractocrinus clementi, Pariocrinus heterodactylus, Homocrinus diminutus, Dendrocrinus parvus, Protaxocrinus cataractensis) are described. The asteroid species Mesopalaeaster granti (Spencer) and Mesopalaeaster? cataractensis Schuchert are tentatively reassigned to Promopalaeaster. The new asteriod genus Medinaster and new species $M$. orbiculus are described.

Exposures of the Cabot Head Formation at Ball's Falls on Twenty Mile Creek near Jordan, Ontario, yielded most of the study material. The fine preservation of crinoids at this locality may reflect a facies-controlled preservational bias. These echinoderms are thought to represent biocoenoses that resulted from the catastrophic burial of entire stands of these organisms in a prodeltaic regime characterized by rapid changes in sedimentation. Echinoderm debris present in equivalent platform strata to the west and north of Ball's Falls may indicate that slower, more uniform rates of sedimentation occurred in these areas.

Distributary sands were supplied to the present-day Ball's Falls area by a northerly extending lobe of the Medinan deltaic complex during the Early Llandovery. Here, sediments were reworked by longshore currents, resulting in the formation of submarine sandbars that were colonized by crinoids. The Ball's Falls fauna is a low-diversity assemblage typical of marginal palaeoenvironments. Rapid changes in sedimentation, localized reducing conditions, and substrates unfavourable to many organisms inhibited colonization of the sea floor. The success of pelmatozoans in exploiting this environment is largely attributable to adaptive advantage conferred by height above the substrate. Attachment modes charac- 
terized by semi-permanent fixation also assisted colonization.

Localized occurrences of crinoids in the Cabot Head Formation represent small, densely populated stands of these organisms. These crinoid communities show evidence of niche partitioning. Intraspecific and interspecific variation in column length permitted crinoids to feed at different levels, optimizing food-gathering efficiency and population density. Utilization of food particles of different sizes may have enhanced co-existence of camerates and inadunates. Rheophilic filter feeding was used by the majority of these echinoderms. Vertically held collecting-bowl configurations may have augmented feeding during periods of slack current.
Taxonomic diversity of echinoderms was low during Late Ordovician and Early Silurian times and is correlated with regression of epicontinental seas that resulted from glacio-eustatic drawdown. This in turn precipitated a time of crisis in many groups of marine invertebrates. Most of the crinoids of the Cabot Head Formation are judged to be descendents of endemic Ordovician species that radiated from carbonates of the continental interior following a new transgressive phase. Accelerated taxonomic diversification of crinoids did not occur until the Late Llandovery, when benthic communities were influenced by greater environmental stability on widespread, newly created carbonate platforms.

\section{Acknowledgements}

This study formed part of the requirements for my M.Sc. degree at the University of Toronto. I am indebted to the members of my committee, Drs. Peter von Bitter (Supervisor), Rolf Ludvigsen, David Kobluk, and Bruce Haugh for their advice and guidance during my graduate studies. I thank Drs. William Ausich, James Brower, and N. Gary Lane for critically reviewing this manuscript, and Dr. Jon Branstrator for comments on asteroid taxonomy. Appreciation is extended to Mrs. Hilary Plint-Geberl for encouragement and advice during the research period. Mrs. Janet B. Waddington of the Royal Ontario Museum kindly permitted my access to the collections, and Dr.
Peter von Bitter provided preparation facilities and photographic equipment. Mr. Robert Brewster and Dr. Rolf Ludvigsen provided information on photographic techniques. Mr. David Rudkin provided stimulating discussions on fossil crinoids. I am especially indebted to Mr. Craig Clement, who discovered many of the specimens used in this study. Dr. Carlton Brett donated several important specimens. Mr. William Parkins assisted in the field. Financial support for this study was provided in part by the University of Toronto and the Royal Ontario Museum. 


\section{Appendix}

\section{Register of Localities}

1. National Topographic Series Niagara 30M/3. Complete section of the Medina Group (Cataract Group equivalent) exposed along the east side of the Niagara Gorge, $1.6 \mathrm{~km}$ south of Lewiston, Niagara County, New York. $43^{\circ} 09^{\prime} 30^{\prime \prime}$ N. Lat. $79^{\circ} 02^{\prime} 40^{\prime \prime}$ W. Long.

2. NTS Niagara $30 \mathrm{M} / 3$. Complete section of the Cataract Group exposed on property of Ontario Hydro, DeCew Falls, St. Catharines, Lincoln County, Ontario. $43^{\circ} 06^{\prime} 25^{\prime \prime}$ N. Lat., $79^{\circ} 15^{\prime} 43^{\prime \prime}$ W. Long.

3. NTS Niagara $30 \mathrm{M} / 3$. Upper part of the Cabot Head Formation exposed at the base of the lower falls, Ball's Falls, Twenty Mile Creek, Jordan, Lincoln County, Ontario, $11 \mathrm{~km}$ west of St. Catharines. $43^{\circ} 08^{\prime} 15^{\prime \prime}$ N. Lat., $79^{\circ} 23^{\prime} 04^{\prime \prime}$ W. Long. Remainder of Cabot Head Formation exposed in high bank $0.4 \mathrm{~km}$ downstream from falls. $43^{\circ} 08^{\prime} 15^{\prime \prime} \mathrm{N}$. Lat., $79^{\circ} 22^{\prime} 44^{\prime \prime}$ W. Long.

4. NTS Niagara $30 \mathrm{M} / 3$. Complete section of the Cataract Group exposed in the gorge locally known as Devil's Punch Bowl, Stoney Creek, Wentworth County, Ontario, $1.6 \mathrm{~km}$ east of Highway 20. $43^{\circ} 11^{\prime} 51^{\prime \prime}$ N. Lat., $79^{\circ} 45^{\prime} 26^{\prime \prime} \mathrm{W}$. Long.

5. NTS Orangeville 40P/16. Exposure of the Whirlpool, Manitoulin, and Cabot Head formations in the gorge of the Credit River near Cataract, Peel County, Ontario, $0.3 \mathrm{~km}$ south of Highway $24.43^{\circ} 50^{\prime} 00^{\prime \prime} \mathrm{N}$. Lat., $80^{\circ} 01^{\prime} 14^{\prime \prime} \mathrm{W}$. Long. 


\section{Literature Cited}

AMSDEN, T. W.

1974 Late Ordovician and Early Silurian articulate brachiopods from Oklahoma, southwestern Illinois and eastern Missouri. Oklahoma Geological Survey, Bulletin 119:1-154.

ANGELIN, N. P.

1878 Iconographia crinoideorum in stratis sueciae Siluricis fossilium. Holmiae, Samson and Wallin. 62 pp.

AUSICH, W. I.

1980 A model for niche differentiation in Lower Mississippian crinoid communities. Journal of Paleontology 54:273-288.

1983 Functional morphology and feeding dynamics of the Early Mississippian crinoid Barycrinus astericus. Journal of Paleontology 57:31-41.

AUSICH, W. I., T. W. KRAMER, and N. G. LANE

1979 Fossil communities of the Borden (Mississippian) delta in Indiana and northern Kentucky. Journal of Paleontology 53:1182-1196.

BARNES, R. D.

1974 Invertebrate zoology. Toronto, W. B. Saunders. 870 pp.

BASSLER, R. S

1938 Pelmatozoa palaeozoica. In Fossilium catalogus 1: Animalia. Berlin, W. Junk, pars 83, pp. 1-194.

BASSLER, R. S. and M. W. MOODEY

1943 Bibliography and faunal index of Paleozoic pelmatozoan echinoderms. Geological Society of America, Special Paper 45:1-734.

BATHER, F. A

1899 A phylogenetic classification of the Pelmatozoa. British Association for the Advancement of Science, Report for 1898:916-923.

BERRY, W. B. N. and A. J. BOUCOT

1970 Correlation of the North American Silurian rocks. Geological Society of America, Special Paper 102:1-289.

1973 Glacio-eustatic control of Late Ordovician-Early Silurian platform sedimentation and faunal changes. Geological Society of America, Bulletin 84:275-284.

BILLINGS, E.

1857 Report for the year 1856 [fossils from Anticosti, and new species of fossils from the Lower Silurian rocks of Canada]. Geological Survey of Canada, Report of Progress 1853-1856:247-345.

1859 On the Crinoideae of the Lower Silurian rocks of Canada. Geological Survey of Canada, Figures and Description of Canadian Organic Remains, Decade $4: 7-66$

BLAINVILLE, H. M. de

1830 Dictionnaire des sciences naturelles. Paris, Levrault. $631 \mathrm{pp}$
BOLTON, T. E.

1953 Silurian formations of the Niagara Escarpment in Ontario. Geological Survey of Canada, Paper 5323:1-19.

1957 Silurian stratigraphy and palaeontology of the Niagara Escarpment in Ontario. Geological Survey of Canada, Memoir 289:1-145

BOOLOOTIAN, R. A

1966 Reproductive physiology. In Boolootian, R. A., ed., Physiology of Echinodermata. New York, Interscience, pp. $561-614$.

BOUCOT, A. J.

1975 Evolution and extinction rate controls. New York, Elsevier. 427 pp.

BOWSHER, A. L.

1955 Origin and adaptation of platyceratid gastropods. University of Kansas Paleontological Contributions, Mollusca, Article 5:1-11.

BRANSTRATOR, J, W.

1979 Asteroidea (Echinodermata). In Contributions to the Ordovician Paleontology of Kentucky and nearby states. United States Geological Survey, Professional Paper 1066F:1-7.

BREIMER, A.

1969 A contribution to the paleoecology of Paleozoic stalked crinoids. Köninklijke Nederlandse Akademie van Wetenschappen, Proceedings, Ser. B, 50:139150.

BREIMER, A. and G. D. WEBSTER

1975 A further contribution to the paleoecology of fossil stalked crinoids. Köninklijke Nederlandse Akademie van Wetenschappen, Proceedings, Ser. B, 78:149167.

BRETT, C. E

1978a Description and paleoecology of a new Lower Silurian camerate crinoid. Journal of Paleontology 52:91-103.

1978b Systematics and paleoecology of Late Silurian (Wenlockian) pelmatozoan echinoderms from western New York and Ontario Ph.D. Thesis, University of Michigan. $595 \mathrm{pp}$.

1978c Host-specific pit-forming epizoans on Silurian crinoids. Lethaia 11:217-232.

1981a Systematics and paleoecology of Late Silurian (Wenlockian) calceocrinid crinoids from New York and Ontario. Journal of Paleontology 55:145-175.

$1981 \mathrm{~b}$ Terminology and functional morphology of attachment structures in pelmatozoan echinoderms. Lethaia $4: 343-370$

BRETT, C. E. and J. D. ECKERT

1982 Palaeoecology of a well-preserved crinoid colony from the Silurian Rochester Shale in Ontario. Royal Ontario Museum, Life Sciences Contributions $131: 1-20$ 
BRETT, C. E. and W. D. LIDDELL

1978 Preservation and paleoecology of a Middle Ordovician hardground community. Paleobiology 4:329348.

BROWER, J. C.

1966 Functional morphology of Calceocrinidae with description of some new species. Journal of Paleontology $40: 613-643$.

1973 Crinoids from the Girardeau Limestone (Ordovician) Palaeontographica Americana 7:259-499.

1975 Crinoids from the Pentland Hills, Scotland. Palaeontology 18:631-656.

1977 Calceocrinids from the Bromide Formation (Middle Ordovician) of southern Oklahoma. Oklahoma Geological Survey, Circular 78:1-25.

BROWER, J. C. and J. VEINUS

1978 Middle Ordovician crinoids from the Twin Cities area of Minnesota. Bulletins of American Paleontology $74: 372-506$.

BROWER, J. C. and H. L. STRIMPLE

1983 Ordovician calceocrinids from northern Iowa and southern Minnesota. Journal of Paleontology $57: 1261-1281$.

COCKS, L. R. M., C. H. HOLLAND, R. B. RICKARDS, and T. STRACHAN

1971 A correlation of Silurian rocks in the British Isles Journal of the Geological Society of London $127: 103-136$

COPPER, P.

1978 Paleoenvironments and paleocommunities in the Ordovician-Silurian sequence of Manitoulin Island. In Sandford, J. T. and R. E. Mosher, eds., Geology of the Manitoulin area. Michigan Basin Geological Society, Special Paper 3:47-62.

1982 Early Silurian atrypoids from Manitoulin Island and Bruce Peninsula, Ontario. Journal of Paleontology 56:680-702.

CRISP, D. J. and P. S. MEADOWS

1967 The chemical basis of gregariousness in barnacles Proceedings of the Royal Society of London, Ser. B, 156:500-520.

DENNISON, J. M

1976 Appalachian Queenston delta related to eustatic sea-level drop accompanying Late Ordovician glaciation centered in Africa. In Basset, M. G., ed., The Ordovician system. Cardiff, University of Wales Press and National Museum of Wales, pp. 107-120.

DOBZHANSKY, T., F. J. AYALA, G. L. STEBBINS, and J. W. VALENTINE

1977 Evolution. San Franscisco, W. H. Freeman. 572 pp.

EHRENBERG, $\mathrm{K}$

1929 Pelmatozoan root-forms (fixation). Bulletin of the American Museum of Natural History 59:1-76.

ELDRIDGE, N

1974 Stability, diversity, and speciation in Paleozoic epeiric seas. Journal of Paleontology 41:1121-1125

FISHER, D. W

1954 Stratigraphy of Medinan Group, New York and Ontario. Bulletin of the American Association of Petroleum Geologists 38: 1979-1996.
FOERSTE, A. F

1919 Echinodermata of the Brassfield (Silurian) Formation of Ohio. Denison University Science Laboratory, Bulletin 18:3-31

1936 Several new Silurian cephalopods and crinoids, chiefly from Ohio and Hudson Bay. Ohio Journal of Science 36:261-275.

FRANZÉN, C

1974 Epizoans on Silurian-Devonian crinoids. Lethaia 7:287-301

1977 Crinoid holdfasts from the Silurian of Gotland. Lethaia 10:219-234

GIETZ, O

1954 The Whirlpool Sandstone, southwestern Ontario. Canadian Mining Journal 75:102. [Abstract]

HALL, $J$

1847 Palaeontology of New York. Volume 1, containing descriptions of the organic remains of the lower division of the New York System. Albany, Printed by C. Van Benthuysen. $338 \mathrm{pp}$

1852 Palaeontology of New York. Volume 2, containing descriptions of the organic remains of the lower middle division of the New York System. Albany, Printed by C. Van Benthuysen. 362 pp.

1860 Observations upon a new genus of Crinoidea: Cheirocrinus. New York State Cabinet of Natural History, Annual Report 13:121-124.

1868 Note on the genus Palaeaster, with description of some new species, and observations upon those previously described. New York State Museum of Natural History, Annual Report 20:282-303.

1872 Description of new species of Crinoidea and other fossils from strata of the age of the Hudson-River group and Trenton Limestone. New York State Museum of Natural History, Annual Report 24:205224

HALLECK, M. S

1973 Crinoids, hardgrounds, and community succession; the Silurian Laurel-Waldron contact in southern Indiana. Lethaia 6:239-251.

HANTZCHEL, W

1975 Trace fossils and problematica. In Moore, R. C. ed., Treatise on invertebrate paleontology, part W, Miscellanea. Lawrence, Geological Society of America and University of Kansas Press, pp. 1-269.

HARRINGTON, J. W. and W. G. HEASLIP

1978 Biostratigraphy and paleoecology of the Upper Devonian Ithaca Formation near Cortland, New York. In D. F. Merriam, ed., New York State Geological Association, 50th Annual Meeting, Syracuse, Guidebook, pp. 344-353.

HAUGH, B. N

1975 Nervous systems of Mississippian camerate crinoids. Paleobiology 1:261-272.

1978 Biodynamic and phyletic paradigms for sensory organs in camerate crinoids. Lethaia 11:145-173. 
1979 Late Ordovician channel-dwelling crinoids from southern Ontario. American Museum Novitates 2665:1-25.

JAEKEL, O.

1918 Phylogenie und System der Pelmatozoen. Paläontologische Zeitschrift Bd. 3:1-128.

JOHNSON, H.

1934 The stratigraphy and palaeontology of the Cataract Formation in Ontario. Ph.D. Thesis, University of Toronto. $100 \mathrm{pp}$.

JOHNSON, M. E. and G. T. CAMPBELL

1980 Recurrent carbonate environments in the lower Silurian of northern Michigan and their inter-regional correlation. Journal of Paleontology 54:1041-1057.

JOHNSON, R. G.

1964 The community approach to paleoecology. In Imbrie, J. and N. D. Newell, eds., Approaches to paleoecology. New York, J. Wiley, pp. 107-134

KESLING, R. V. and J. P. SIGLER

1969 Cunctocrinus, a new Middle Devonian calceocrinid from the Silica Shale of Ohio. Contributions from the Museum of Paleontology, University of Michigan, 22:339-360.

KESLING, R. V. and H. L. STRIMPLE

1971 Eutaxocrinus wideneri, a new flexible crinoid from the Middle Devonian Silica Formation of northwestern Ohio. Contributions from the Museum of Paleontology, University of Michigan, 23:291-303.

KIRK, E. R.

1911 The structure and relationships of certain eleutherozoic Pelmatozoa. Proceedings of the United States National Museum 41:1-137.

1914 Notes on the fossil genus Homocrinus Hall. Proceedings of the United States National Museum 46:473483 .

KNIGHT-JONES, E. W.

1953 Laboratory experiments on gregariousness during settling in Balanus balanoides and other barnacles. Journal of Experimental Biology 30:584-598.

LAMARCK, J. B.

1816 Histoire naturelle des animaux sans vertèbres. Paris, Verdière, vol. 2. $568 \mathrm{pp}$.

LANE, N. G.

1972 Synecology of Middle Mississippian (Carboniferous) crinoid communities in Indiana. 24th International Geological Congress, Montreal, 1972, Section 7 , Paleontology, pp. 89-94.

1973 Paleontology and paleoecology of the Crawfordsville fossil site (Upper Osagian, Indiana). University of California Publications in Geological Sciences 99:1141 .

1978 Synecology of fossil crinoids. In Moore, R. C., ed., Treatise on invertebrate paleontology, part $\mathrm{T}$, Echinodermata 2. Lawrence, Geological Society of America and University of Kansas Press, pp. 343-347.
LANE, N. G. and A. BREIMER

1974 Arm types and feeding habits of Paleozoic crinoids. Köninklijke Nederlandse Akademie van Wetenschappen, Proceedings, Ser. B, 77:32-39.

LANE, N. G. and G. D. WEBSTER

1966 New Permian crinoid fauna from southern Nevada. University of California Publications in Geological Sciences 63:1-60.

LESPERANCE, P. J.

1974 The Hirnantian faunas of the Perce area (Quebec) and the Ordovician-Silurian boundary. American Journal of Science 274:10-30.

LEVINTON, J. S

1972 Stability and trophic structure in deposit-feeding and suspension-feeding communities. American Naturalist 106:472-486

LEWIS, R. D.

1982 Holdfasts. In Sprinkle, J. ed., Echinoderm faunas of the Bromide Formation (Middle Ordovician) of Oklahoma. University of Kansas Paleontological Contributions, Monograph 1:57-64.

LIBERTY, B. A. and T. E. BOLTON

1971 Paleozoic geology of the Bruce Peninsula area, Ontario. Geological Survey of Canada, Memoir 360:1-163.

LIDDELL, W. D.

1975 Recent crinoid biostratinomy. Geological Society of America, Abstracts with Programs 7:1169. [Abstract]

MACURDA, D. B., Jr.

1975 The bathymetry and zoogeography of shallow-water crinoids in the Bahama Islands. Hydro-laboratory Journal 3:5-24.

MACURDA, D. B., Jr. and D. L. MEYER

1974 Feeding posture of modern stalked crinoids. Nature 247:394-396

1977 Crinoids of West Indian coral reefs. Studies in Geology 4:231-237.

MARTINI, I. P

1971 Regional analysis of sedimentology of Medina Formation (Silurian), Ontario and New York. American Association of Petroleum Geologists, Bulletin 55:1249-1261

MEEK, F. B.

1872 Description of two new starfishes and a crinoid from the Cincinnati group of Ohio and Indiana. American Journal of Science, Ser. 3:257-262.

MEEK, F. B. and A. H. WORTHEN

1869 Descriptions of new Crinoidea and Echinoidea from the Carboniferous rocks of the western states, with a note on the genus Onychaster. Proceedings of the Academy of Natural Sciences of Philadelphia $21: 61-83$

MEYER, D. L.

1971 Post-mortem disarticulation of recent crinoids and ophiuroids. Geological Society of America, Abstracts with Programs 3:645. [Abstract] 
MEYER, D. L, and N. G. LANE

1976 The feeding behavior of Paleozoic crinoids and Recent basketstars. Journal of Paleontology 50:472480 .

MILLER, J. S

1821 A natural history of the Crinoidea or lily-shaped animals, with observation on the genera Asteria, Euryale, Comatula, and Marsupites. Bristol, Bryan. $150 \mathrm{pp}$

MILLER, S. A.

1883a Description of three new orders and four new families in the class Echinodermata, and eight new species from the Silurian and Devonian formations. Cincinnati Society of Natural History, Journal 5:221-231.

$1883 \mathrm{~b}$ Glyptocrinus defined and restricted, Gaurocrinus, Pycnocrinus, and Compsocrinus established and two new species described. Cincinnati Society of Natural History, Journal 6:217-235.

1889 North American geology and paleontology. Cincinnati, Western Methodist Book Concern. 664 pp.

MOORE, R. C

1950 Evolution of the Crinoidea in relation to major paleogeographic changes in earth history. 18th International Geological Congress, Great Britain, 1948, Report, part 12:27-53.

1952 Evolution rates among crinoids. Journal of Paleontology $26: 338-352$.

1962 Revision of Calceocrinidae. University of Kansas Paleontological Contributions, Echinodermata, Article $4: 1-40$.

MOORE, R. C. and L. R. LAUDON

1943 Evolution and classification of Paleozoic crinoids. Geological Society of America, Special Paper 46:1163.

MOORE, R. C. and H. L. STRIMPLE

1973 Lower Pennsylvanian (Morrowan) crinoids from Arkansas, Oklahoma, and Texas. University of Kansas Paleontological Contributions, Echinodermata 12, Article 60:1-84.

MOORE, R. C., G. UBAGHS, H. RASMUSSEN, A. BREIMER, and N. G. LANE

1978 Glossary of crinoid morphological terms. In Moore, R. C., ed., Treatise on invertebrate paleontology, part T, Echinodermata 2. Lawrence, Geological Society of America and University of Kansas Press, pp. 229-244.

NEWELL, N. D. and A. L. BLOOM

1970 The reef flat and two-meter eustatic terrace of some Pacific atolls. Geological Society of America, Bulletin $81: 1881-1894$.

PAINE, R. T.

1966 Food web complexity and species diversity. American Naturalist 100:65-75.
PERRIER, J. O. E

1884 Mémoire sur les étoiles de mer recueillies dans la mer des Antilles et le golfe du Mexique. Muséum d'histoire naturelle, Nouvelles archives. Sér. 2:127276.

POLLOCK, C. A., C. B. REXROAD, and R. S. NICOLL

1970 Lower Silurian conodonts from northern Michigan and Ontario. Journal of Paleontology 44:743-764.

RASMUSSEN, H. W

1977 Function and interpretation of the stem in Isocrinidae and Pentacrinidae: review and description. Lethaia $10: 51-57$

REXROAD, C. B.

1967 Stratigraphy and conodont paleontology of the Brassfield (Silurian) in the Cincinnati Arch area. Geological Survey of Indiana, Bulletin 36:1-64.

REXROAD, C. B. and L. V. RICKARD

1965 Zonal conodonts from the Silurian strata of the Niagara Gorge. Journal of Paleontology 39:12171220.

RINGUEBERG, E. N.

1889 The Calceocrinidae; a revision of the family with descriptions of some new species. New York Academy of Sciences, Annals 4:388-408.

ROLIFF, W. A

1954 The pre-Middle Ordovician rocks of southwestern Ontario. Proceedings of the Geological Association of Canada 6(2):103-109.

ROWLEY, R. R

1904 The Echinodermata of the Missouri Silurian and a new brachiopod. American Geologist 34:269-282.

RUEDEMANN, $\mathbf{R}$

1916 Account of some new or little known species of fossils, mostly from Paleozoic rocks of New York. New York State Museum, Bulletin 189:7-97.

RYLAND, J, S.

1970 Bryozoans. London, Hutchinson. 175 pp.

SARDESON, F. W

1928 Derivation of the Calceocrinidae. Pan-American Geologist 49:35-46.

SAVAGE, T. E.

1917 Stratigraphy and paleontology of the Alexandrian Series in Illinois and Missouri, part 1. Illinois State Geological Survey, Bulletin 23:67-160.

SCHMIDT, W. E.

1934 Die Crinoideen des rheinischen Devons, Teil 1, Die Crinoideen des Hunsruckschiefer. Abhandlungen der Preussischen Geologischen Landesanstalt, n.F., 163:1-199

SCHOPF, T. J. M

1969 Paleoecology of ectoprocts (bryozoans). Journal of Paleontology 43:324-344. 
SCHUCHERT, C.

1914 Stelleroidea palaeozoica. In Fossilium catalogus 1: Animalia. Berlin, W. Junk, pars 3, pp. 1-53.

1915 Revision of Paleozoic Stelleroidea with special reference to North American Asteroidea. United States National Museum, Bulletin 88:1-311.

SHEEHAN, P. M.

1973 The relation of late Ordovician glaciation to the Ordovician-Silurian changeover in North American brachiopod faunas. Lethaia 6:147-154.

1975 Brachiopod synecology in a time of crisis (Late Ordovician-Early Silurian). Paleobiology 1:205-212.

SPENCER, J. W

1884 Niagara fossils. University of Missouri, Museum Bulletin 1:1-61.

SPENCER, W. K

1951 Early Palaeozoic starfish. Philosophical Transactions of the Royal Society of London, Ser. B, 235:87-129.

SPENCER, W. K. and C. W. WRIGHT

1966 Asterozoans. In Moore, R. C., ed., Treatise on invertebrate paleontology, part $\mathrm{U}$, Echinodermata 3 . Lawrence, Geological Society of America and University of Kansas Press, pp. 4-107.

SPRINGER, F.

1906 Discovery of the disk of Onychocrinus, and further remarks on the Crinoidea Flexibilia. Journal of Geology 14:467-523.

1911 On a Trenton echinoderm fauna at Kirkfield, Ontario. Geological Survey of Canada, Memoir 15:1-68.

1913 Crinoidea. In Zittel von, K. A., Textbook of palaeontology. 2nd ed. London, Macmillan, vol. 1, pp. 173-243.

1919 New species of crinoid [Eucheirocrinus ontario]. In Williams, M. Y., The Silurian geology and faunas of Ontario Peninsula, and Manitoulin and adjacent islands. Geological Survey of Canada, Memoir 111:127.

1920 The Crinoidea Flexibilia. Smithsonian Institution Publication 2501:1-443.

1926 American Silurian crinoids. Smithsonian Institution Publication 2871:1-239.

TIPPER, J. C.

1975 Lower Silurian animal communities-three case histories. Lethaia 8:287-289.

UBAGHS, G.

1978 Skeletal morphology of fossil crinoids. In Moore, R. C., ed., Treatise on invertebrate paleontology, part T, Echinodermata 2. Lawrence, Geological Society of America and University of Kansas Press, pp. 59-216.

ULRICH, E. O

1925 New classification of the "Heterocrinidae". Geological Survey of Canada, Memoir 138:82-104.
VALENTINE, J, W

1969 Patterns of taxonomic and ecological structure of the shelf benthos during Phanerozoic time. Palaeontology 12:684-709.

1971 Resource supply and species diversity patterns. Lethaia 4:51-61.

VAN SANT, J. F. and N. G. LANE

1964 Crawfordsville (Indiana) crinoid studies. University of Kansas Paleontological Contributions, Echinodermata, Article 7:1-136.

WACHSMUTH, C. and F. SPRINGER

1885 Revision of the Palaeocrinoidea. Proceedings of the Academy of Natural Sciences of Philadelphia for 1885:225-364

1886 Revision of the Palaeocrinoidea. Proceedings of the Academy of Natural Sciences of Philadelphia for 1886:64-226.

1897 North American Crinoidea Camerata. Harvard University Museum of Comparative Zoology, Memoir 20:1-837.

WALKER, K. R. and L. P. ALBERSTADT

1975 Ecological succession as an aspect of structure in fossil communities. Paleobiology 1:238-257.

WALKER, K. R. and W. C. PARKER

1976 Population structure of a pioneer and a later stage species in an Ordovician ecological succession. Paleobiology 2:191-201.

WARN, J. M.

1974 Presumed myzostomid infestation of an Ordovician crinoid. Journal of Paleontology 48:506-573.

WARN, J. M. and H. L. STRIMPLE

1977 The disparid inadunate superfamilies Homocrinacea and Cincinnaticrinacea (Echinodermata: Crinoidea), Ordovician-Silurian, North America. Bulletins of American Paleontology 72:1-138.

WATKINS, $R$. and J. M. HURST

1977 Community relations of Silurian crinoids at Dudley, England. Paleobiology 3:207-217.

WEAVER, T. R.

1976 Adaptive strategies of disparid inadunate crinoids of the type Cincinnatian (Upper Ordovician). Geological Society of America, Abstracts with Programs 8:516-517. [Abstract]

WELCH, J. R.

1976 Phosphannulus on Paleozoic crinoid stems. Journal of Paleontology 50:218-225.

WILBUR, H. M., D. W. TINKLE, and J. P. COLLINS

1974 Environmental certainty, trophic level, and resource availability in life history evolution. American Naturalist 108:805-817.

WINDER, C. G. and B. V. SANFORD

1972 Stratigraphy and paleontology of the Paleozoic rocks 
of southern Ontario. 24th International Geological Congress, Montreal, 1972, Guidebook to excursions A 45-C45. $74 \mathrm{pp}$

WITZKE, B. J.

1977 Echinoderms from the Hopkinton Dolomite (Lower Silurian), eastern Iowa. M.Sc. Thesis, University of lowa. 224 pp.

WITZKE, B. M., T. J. FREST, and H. L. STRIMPLE

1979 Biogeography of the Silurian-Lower Devonian echinoderms. In Gray, J. and A. J. Boucot, eds., Historical biogeography, plate tectonics, and the changing environment. Corvallis, Oregon State University Press, pp. 117-129.
WITZKE, B. J. and H. L..STRIMPLE

1981 Early Silurian camerate crinoids of eastern Iowa. Iowa Academy of Science, Proceedings 88:101-137.

ZIEGLER, A. M., K. S. HANSEN, M. E. JOHNSON, M. A. KELLY, C. R. SCOTESE, and R. VAN DER VOO

1977 Silurian continental distributions, paleogeography, climatology, and biogeography. Tectonophysics 40:13-51

ZITTEL, K. A. von

1879 Handbuch der Palaeontologie. Munich, R. Oldenbourg. Bd. 1, Palaeozoologie, pp. 1-765.

1895 Grundzüge der Paläontologie (Paläozoologie). 1st ed. Munich, R. Oldenbourg. $971 \mathrm{pp}$. 
Plates 
Plate 1, figs. $1-4$

Kylixocrinus latus gen. et sp. nov., Cabot Head Formation at Ball's Falls on Twenty Mile Creek near Jordan, Ontario.

1. CD-interray of holotype. Note prominent anastomosing ridge and pustule ornamentation. See also Text-fig. 6A; PI. 2, fig. 1. ROM $38987, \times 3.1$

2. Young adult with exceptionally long pinnules. Note long cirri borne by column. Paratype ROM $38989, \times 1.9$
3. Column and pinnule detail. Cirrals become successively more elongate distally. Proxistele cirri are arranged in irregular fashion; those of mesistele are arranged in whorls. Paratype ROM $38990, \times 3.7$

4. Basal and posterior views of two well-preserved individuals. Note wide CD-interray and anal ridge of individual to left. For specimen to right, see also Text-fig. 6F; Pl. 2, fig. 6. Paratypes ROM 38988a, b, × 1.3 

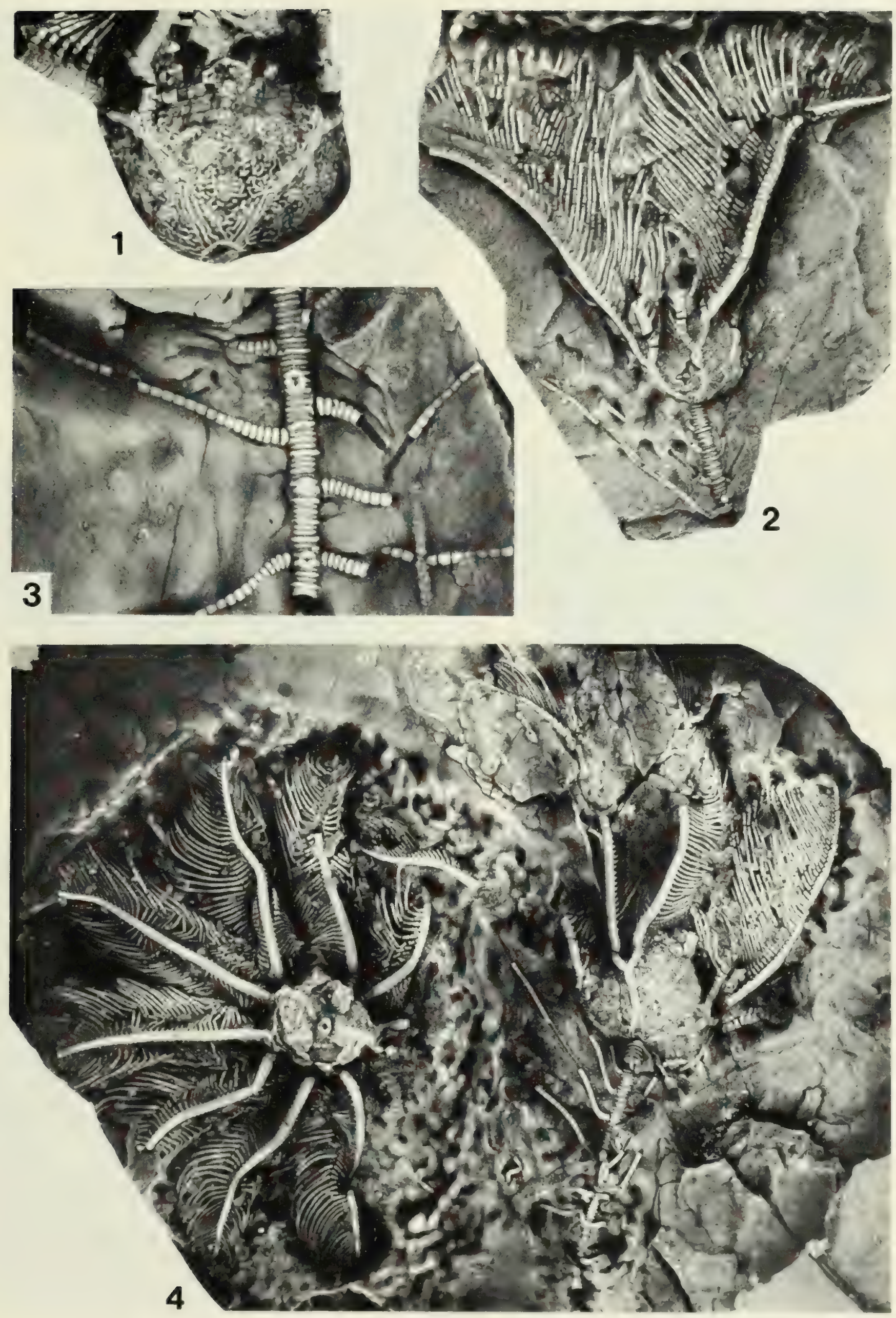
Plate 2, figs. 1-6

Kylixocrinus latus gen. et sp. nov., Cabot Head Formation at Ball's Falls on Twenty Mile Creek near Jordan, Ontario. Ethanol immersion. For diagrams of specimens illustrated on this plate, see Text-fig. $6 \mathrm{~A}-\mathrm{F}$.

1. Holotype viewed from CD-interray. Note large primanal in contact with D-ray radial and bounded on right by smaller anal plate. ROM $38987, \times 4.3$

2. DE-interray of holotype showing typical arrangement of interbrachials, ROM $38987, \times 5.2$

3. Holotype centred on A-ray, ROM $38987, \times 4.9$
4. CD-interray of individual with characteristic wide, bowlshaped aboral cup. Paratype ROM 38992, × 4.4

5. Basal view, with $C D$-interray to lower left. Note anitaxial ridge and narrow median ridges, which flare proximally. Paratype ROM $38995 \mathrm{a}, \times 5.8$

6. CD-interray of largest individual showing prominent anitaxial and ray ridges. Note immature biserial arrangement of free brachials. D-ray contains one intersecundibrachial. Paratype ROM $38988 \mathrm{~b}, \times 3.4$ 

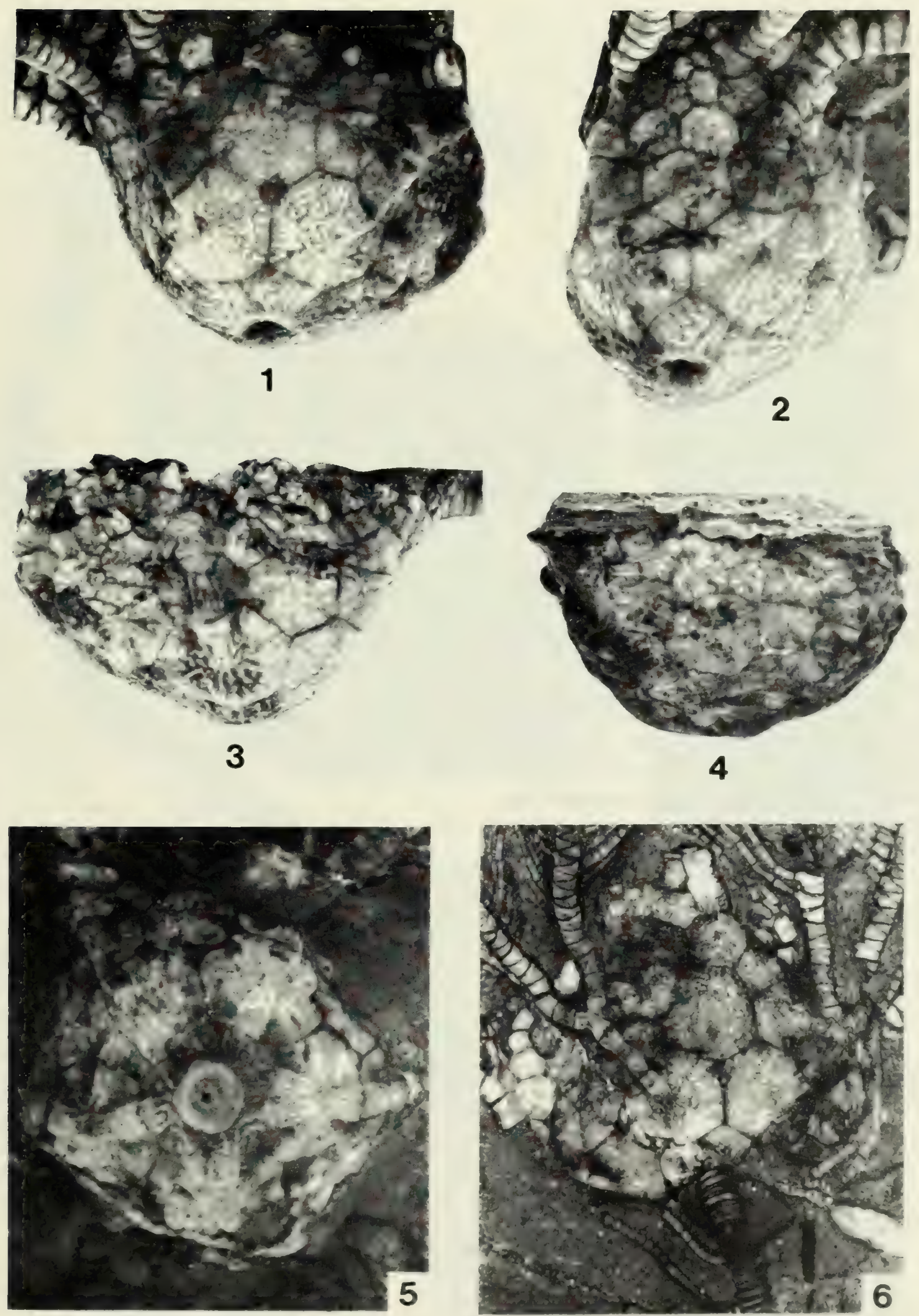
Plate 3, figs. 1-7

Fig. 1 Gastropod Naticonema sp. attached to aboral cup of Ptychocrinus medinensis, ROM 39049, $\times$ 2.3. Cabot Head Formation at Ball's Falls on Twenty Mile Creek near Jordan, Ontario.

Figs. 2-5 Nexocrinus delicatulus gen. et sp. nov.

2. Large individual tentatively assigned to this genus. Recrystallization has made generic assignment uncertain. Nodal columnals bear prominent, downcurved epifacets. Paratype ROM $39050, \times 1.4$. Cabot Head Formation at Ball's Falls on Twenty Mile Creek near Jordan, Ontario.

3. Typical crown centred on BD-interray. Specimen is preserved on upper surface of thin lens of crinoidal debris. Paratype ROM $666 \mathrm{cl}-\mathrm{B}, \times 3.1$. Whirlpool Formation at Cataract, Ontario.

4. Holotype centred on DE-interray. Note faint anitaxial ridge and prominent ridges on rays. Arms are uniserial. See Text-fig. 8 for diagram of this specimen. ROM $666 \mathrm{cl}-\mathrm{A}, \times 5.1$. Whirlpool Formation at Cataract, Ontario.
5. Proximal curvature of column of this individual suggests that this crinoid may have lived in a recumbent position with stem resting on substrate. ROM 39051, × 2.4. Cabot Head Formation at Ball's Falls on Twenty Mile Creek near Jordan, Ontario.

6. Cyathocystid or pyrgocystid stalked edrioasteroid. The stalk, apparently attached to a gastropod shell, is composed of a series of imbricating plates. Jumbled plates near top probably represent remains of theca. RoM 39052, × 2.4. Cabot Head Formation at Ball's Falls on Twenty Mile Creek near Jordan, Ontario.

7. Large individual of Ptychocrinus medinensis displaying well-preserved arms, which branch twice above cup. ROM 39002, × 1.0. Cabot Head Formation at Ball's Falls on Twenty Mile Creek near Jordan, Ontario. 

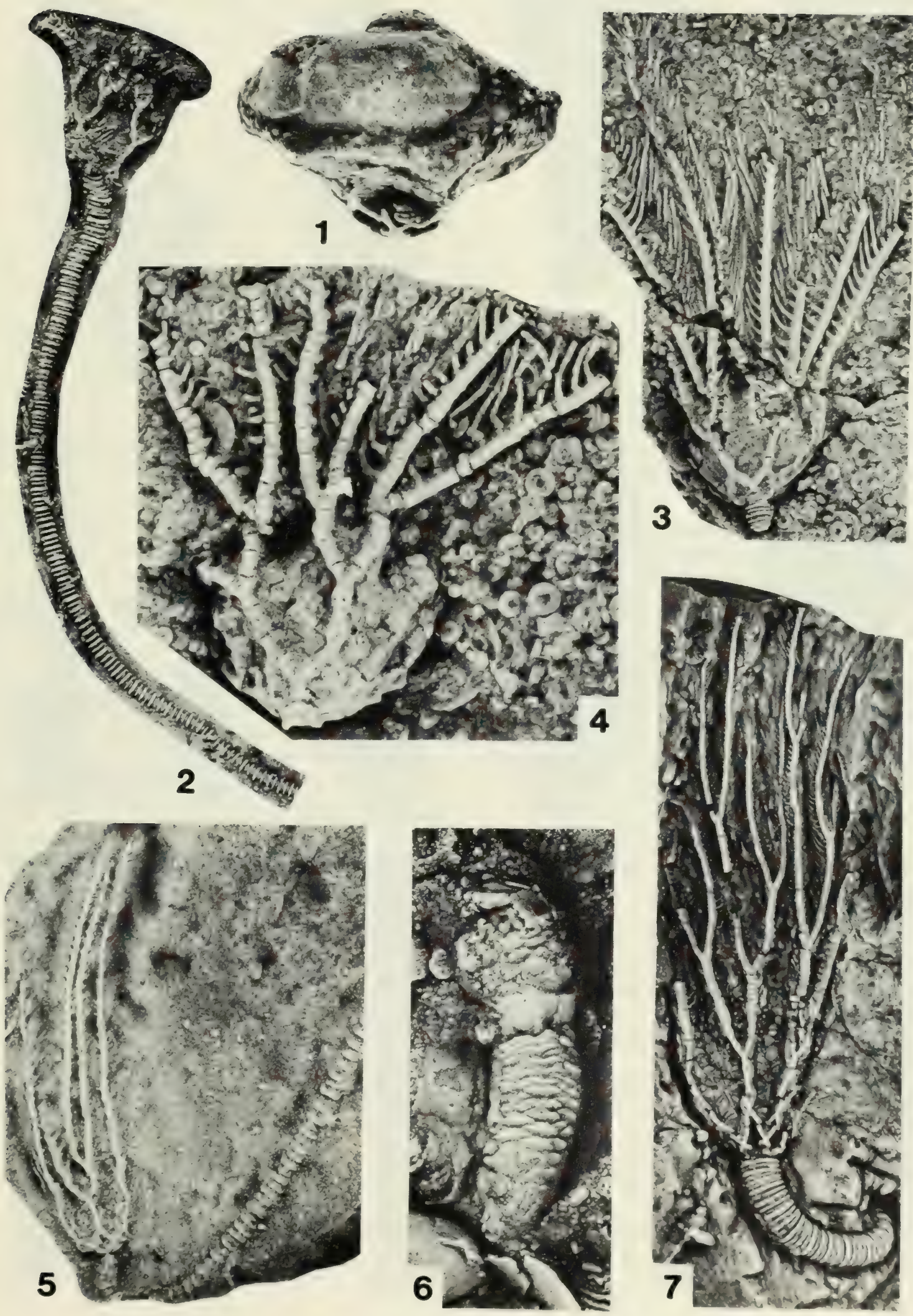
Plate 4 , figs. $1-12$

Figs. 1-4 Diaphorocrinus pleniramulus gen. et sp. nov. Cabot Head Formation at Devil's Punch Bowl near Stoney Creek, Ontario.

1. Holotype viewed from D-ray. Note repeated bifurcations of five axil arms that differentiate Diaphorocrinus from the majority of calceocrinids. Close abutment of axil arms near caly $x$ conceals their proximal branches. See Text-fig. 11 A for diagram of this specimen. ROM $39010 \mathrm{a}, \times 2.2$

2. D-ray view of crown of adult. Axil arms are tightly closed in a defensive posture, which conceals much of their structure. Proximal plates are preserved. See Text-fig. 11B for diagram of this specimen. Paratype ROM $39010 \mathrm{~b}, \times 2.3$

3. A-ray view of partial specimen. Note distinctive ornamentation of small pits, which commonly coalesce and produce irregular ridges. Paratype ROM 39010c, $\times 3.4$

4. E-ray view of above, showing bifurcation of ray on third primibrachial. E-ray inferradial tapers distally and is in contact with superradial. See Text-fig. 11D for diagram of this specimen. Paratype ROM $39010 \mathrm{c}, \times 2.8$

Figs. 5-9 Calceocrinus tridactylus sp. nov. Cabot Head Formation at Ball's Falls on Twenty Mile Creek near Jordan, Ontario.

5. Holotype viewed from E-ray. E-ray radial is constricted distally and is in contact with superradial. See Text-fig. 10B for diagram of this specimen. ROM $39007, \times 1.9$
6. Posterior view of above. Only proximal portion of anal tube is exposed. Holotype ROM $39007, \times 1.9$

7. D-ray view of holotype showing five axil arms. An extra plate is interposed between first and second main axils. See Text-fig. $10 \mathrm{~A}$ for diagram of this specimen. ROM $39007, \times 1.9$

8. A-ray view of holotype, ROM $39007, \times 1.9$

9. E-ray view of individual with prominent ornamentation. See Text-fig. 10C for diagram of this specimen. Paratype ROM $39008, \times 2.3$

Figs. 10, 11 Indeterminate calceocrinids. Cabot Head Formation at Devil's Punch Bowl near Stoney Creek, Ontario,

10. D-ray view of unique individual. Primaxil arm bifurcates repeatedly, unlike primaxil arms of all calceocrinids except Diaphorocrinus gen. nov. This individual may be an abnormal specimen of Calceocrinus or may possibly represent a new genus. ROM 39066a, × 2.3

11. A-ray view of juvenile calceocrinid, possibly Calceocrinus . Note sparse branching of axil arms and elongate brachials. Anal tube is especially prominent. ROM $39066 \mathrm{~b}, \times 4.2$

Fig. 12 Holotype of Calceocrinus pustulosus Brower, viewed from A-ray. See Text-fig. 9 for diagram of this specimen. ROM $628 \mathrm{c} 1, \times 2.2$ Manitoulin Formation at Devil's Punch Bowl near Stoney Creek, Ontario. 

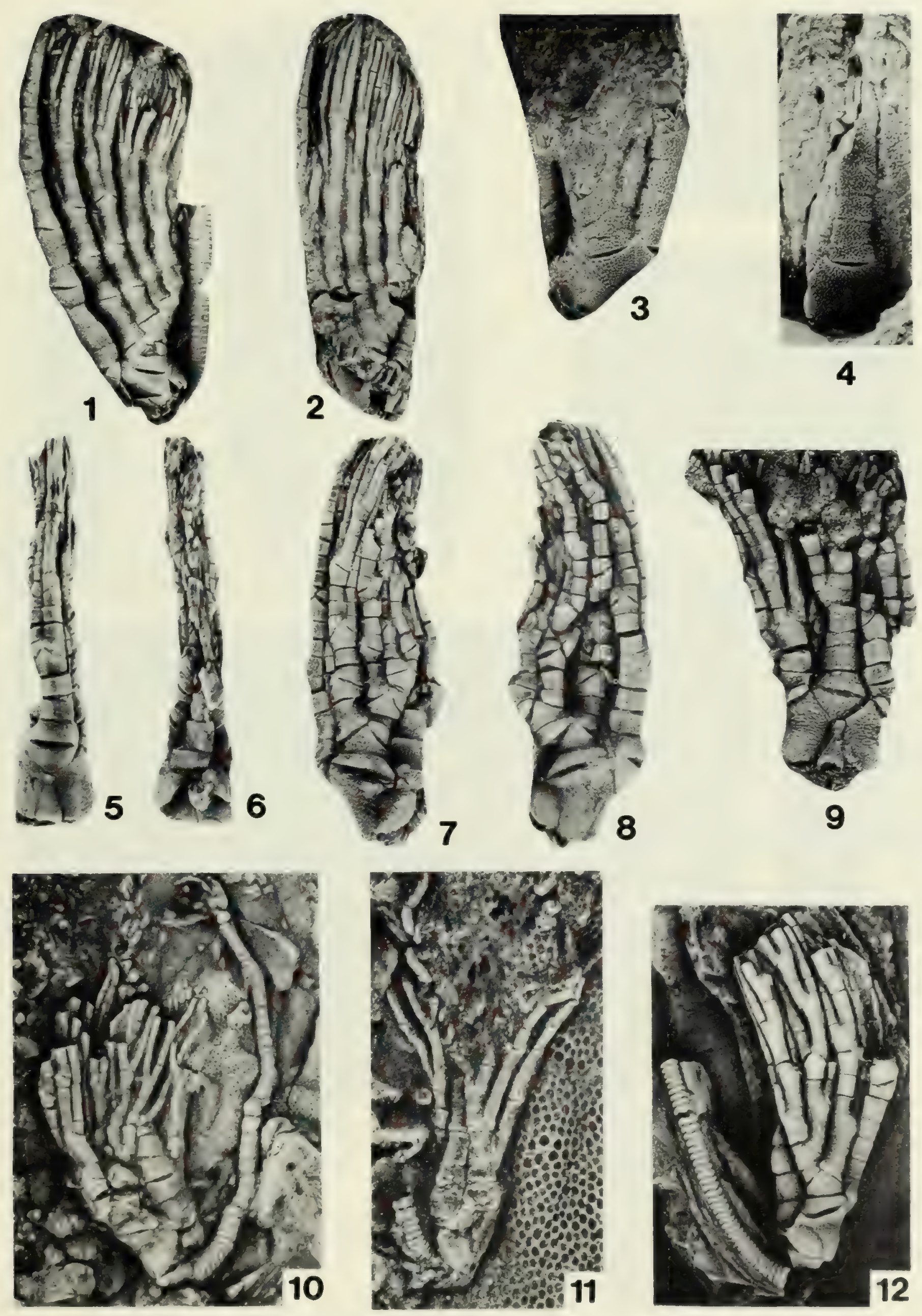
Plate 5, figs, 1-9

Cataractocrinus clementi gen. et sp. nov. Cabot Head Formation at Ball's Falls on Twenty Mile Creek near Jordan, Ontario.

1. Holotype centred on C-ray. Basals are missing. Note compound radials and elongate distal plates of long anal appendage, which is supported by C-ray superradial. See Text-fig. 12A for diagram of this specimen. ROM 39011, $\times 3.7$

2. Anterior view of average-sized individual. Note isotomously. branching arms and articulating notches between proximal brachials that aided arm movement. See Text-fig. 12B for a diagram of this specimen. Paratype ROM $39012, \times 5.1$

3. Anterior view, paratype ROM $39014, \times 4.1$

4. Holdfast displaying long, apparently unbranched radicles, paratype ROM $39010, \times 2.4$

5. Holdfast. Note homoeomorphic, pentameric nature of dististele and sparse branching of radicles. Paratype ROM 39018, $x$ 4.2
6. Anterior view of individual with well-preserved arms. Ventral surface of ray to right exposes wide, shallow ambulacral groove. Paratype ROM $39013, \times 4.8$

7. Anterior view of partial specimen. Note proximal tapering of inferradials and slight tapering of primibrachial in centre ray. See Text-fig. 12D for diagram of this specimen. Paratype ROM $39016, \times 5.5$

8. Anterior view of only individual found attached to stem, paratype ROM $39017, \times 2.3$

9. Enlargement of above showing basals and heteromorphic proxistele. See Text-fig. 12C for diagram of this specimen. Paratype ROM $39017, \times 31$ 

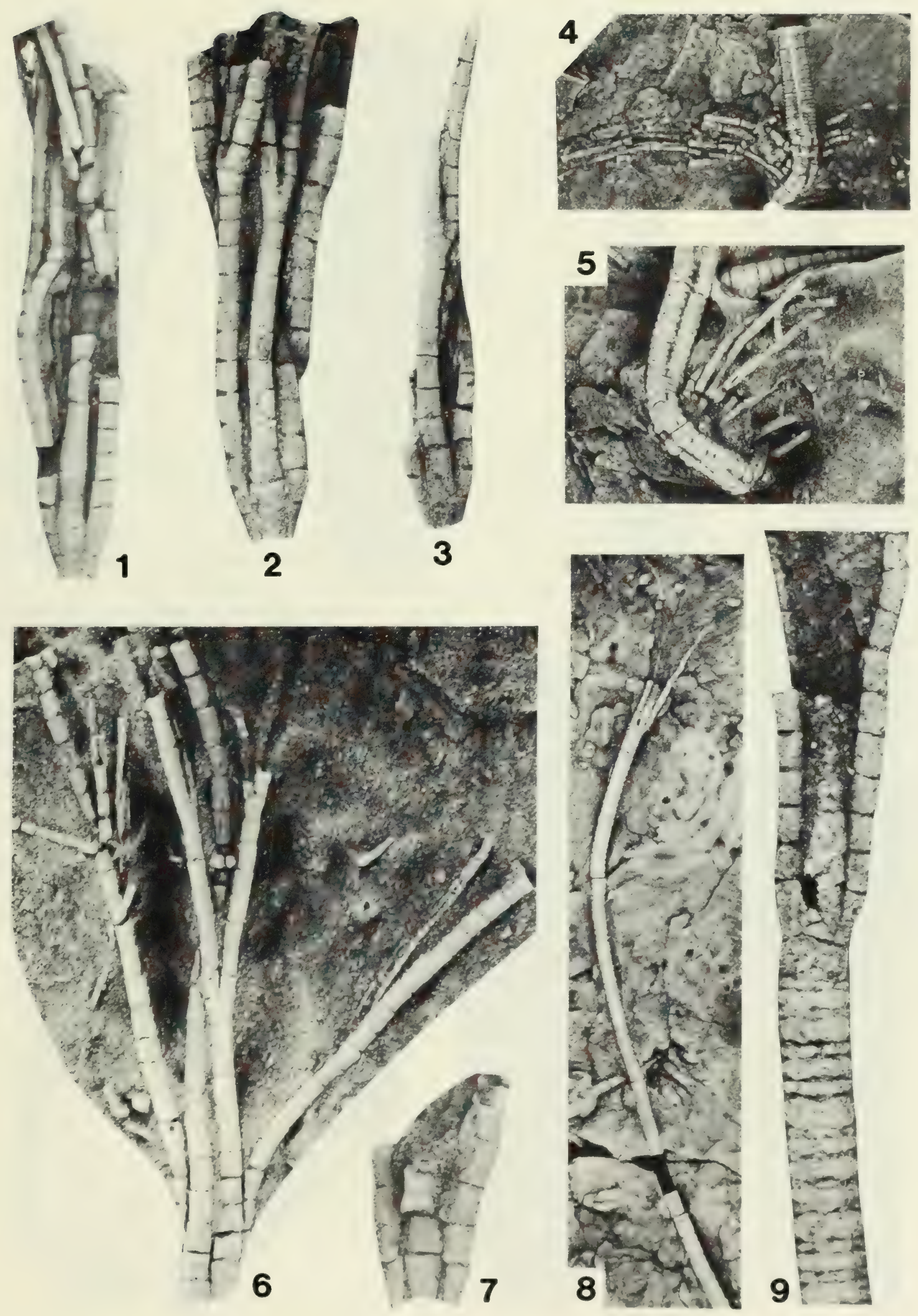
Plate 6, figs. 1-10

Figs. 1-6 Pariocrinus heterodactylus gen. et sp. nov. Cabot Head Formation at Ball's Falls on Twenty Mile Creek near Jordan, Ontario.

1. Holotype viewed from CD-interray. Note wide anibrachial that supports long anal appendage on left and heterotomously branching arms on right. See Text-fig. 13A for diagram of this specimen. ROM $39026, \times 7.4$

2. Anterior view of crushed individual. See Text-fig. 13B for diagram of this specimen. Paratype ROM 39027, $\times 10.1$

3. Individual centred on B-ray. Note long anal appendage of C-ray composed of greatly elongated plates. Paratype ROM $39030, \times 7.6$

4. Individual centred on C-ray. Note C-ray anibrachial extending well beyond distal facet of B-ray radial and supporting anal appendage on left. See Text-fig. 13C for diagram of this specimen. Paratype ROM 39029a, $\times 4.5$

5. Anterior view of typical individual. Note peneplenary, straight to slightly curved radial facets and heteromorphic stem. See Text-fig. 13D for diagram of this specimen. Paratype RoM $39028, \times 3.9$

6. Enlargement of above, paratype ROM $39028, \times 7.8$
Fig. 7-9 Homocrinus diminutus sp. nov. Cabot Head Formation at Ball's Falls on Twenty Mile Creek near Jordan, Ontario.

7. Indeterminate orientation of corroded specimen. Arms, incomplete in this individual, are composed of greatly elongated brachials. Paratype ROM 39021, × 9.3

8. Lateral view of typical individual. Heteromorphic stem of this species differs from xenomorphic column of Homocrinus parvus (Pl. 6, fig. 10). Paratype ROM 39022, × 7.2

9. Lateral view of holotype. Basals of this specimen are missing. Ray to left contains compound radial; ray to right has undivided radial. Note single fixed primibrachial in each ray. See Text-fig. 14 for diagram of this specimen. ROM $39020, \times 7.5$

Fig. 10 Homocrinus parvus, type species. CD-interray view of well-preserved individual from Rochester Formation (Upper Silurian, Wenlockian) at Thorold, Ontario. ROM $39025, \times 9.3$ 

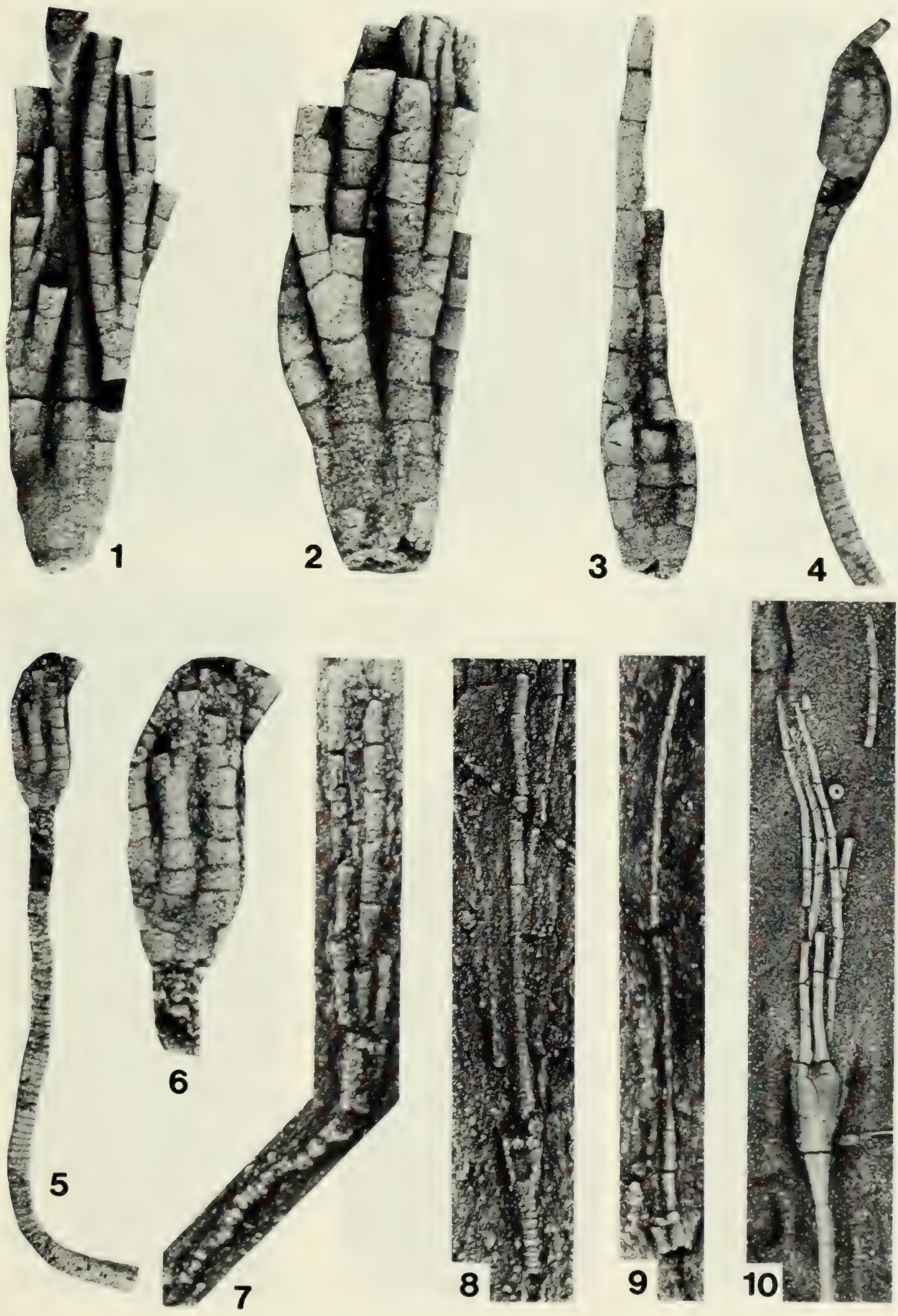
Plate 7, figs. 1-6

Figs. 1, 2 Calceocrinid holdfasts. Cabot Head Formation at Devil's Punch Bowl near Stoney Creek, Ontario.

1. Holdfast attached to fragment of frondose bryozoan. Note asymmetric placement of sloping stem cicatrix. ROM 39054, $\times$ 3.1

2. Holdfast attached to bryozoan, ROM $39055, \times 4.8$

Figs. 3-6 Dendrocrinus parvus sp. nov. Cabot Head Formation at Ball's Falls on Twenty Mile Creek near Jordan, Ontario.

3. Holotype viewed from CD-interray. Note position of radianal directly below C-ray radial and note arcuate, peneplenary nature of radial facets. Pustulose appearance of plates is a result of pyritization. See Text-fig. 15A for diagram of this specimen. ROM $39037, \times 8.6$
4. Anterior view of small individual with well-preserved arms. Specimen is crushed in plane of photograph. Partially disarticulated individual is present at upper right. See Text-fig. 15B for diagram of better of two specimens. Paratypes ROM 39038a, b, $\times$ 5.0

5. Anterior view of typical specimen. Concave sides of cup resulted from crushing during diagenesis. See Text-fig. 15C for diagram of this specimen. Paratype ROM 39039, $\times 8.0$

6. Anterior view of unusually large individual with wellpreserved anal tube and most of heteromorphic stem. Note plicate nature of anal plates. Paratype ROM $39043, \times 8.0$ 

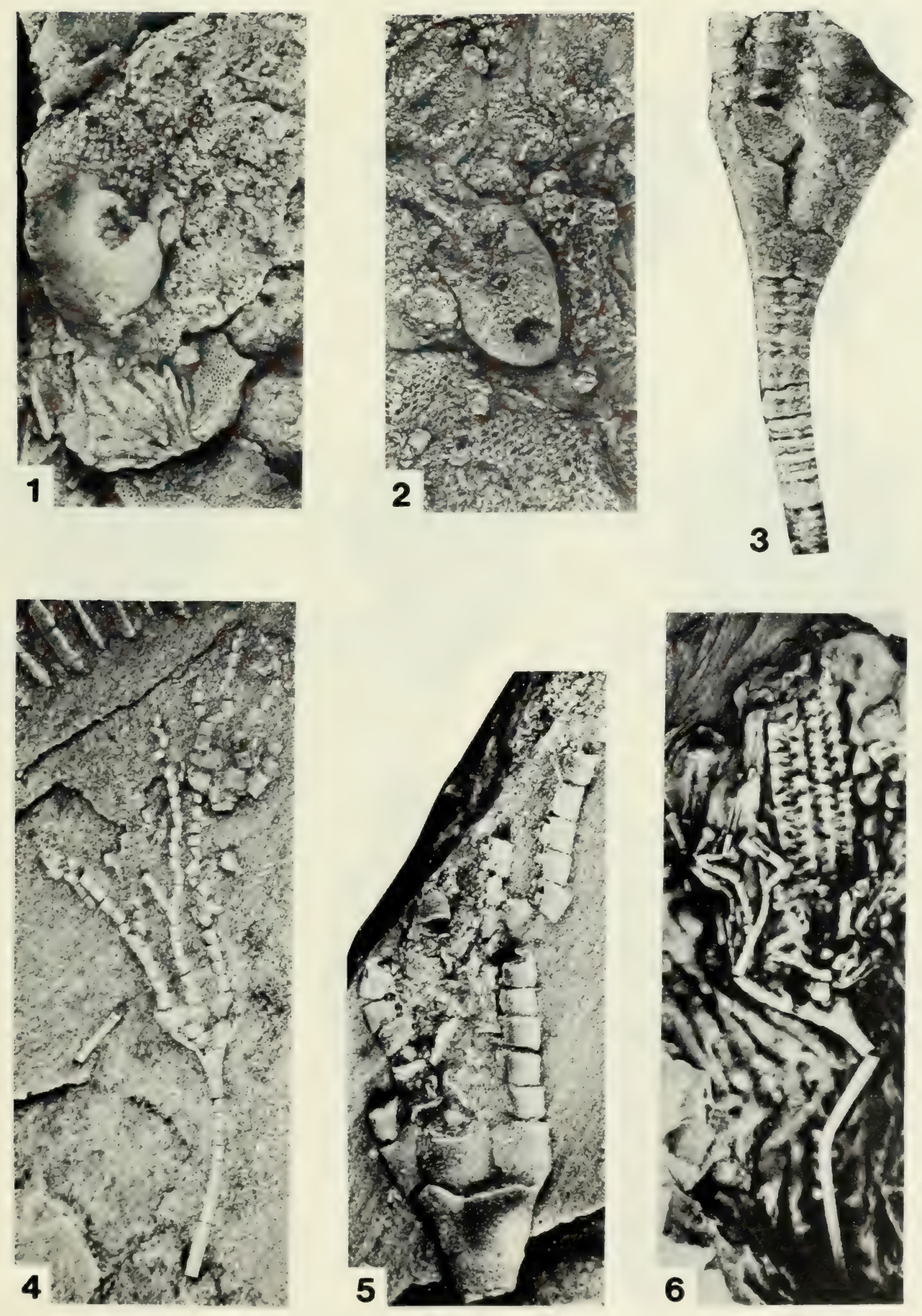
Plate 8 , figs. $1-9$

Protaxocrinus cataractensis sp. nov. Cabot Head Formation at Ball's Falls on Twenty Mile Creek near Jordan, Ontario.

1. Largest individual centred on B-ray. Specimen is crushed in plane of photograph. Paratype ROM 39004, $\times 3.1$

2. Adoral view of above showing incurling arms with slight sinistral torsion, paratype ROM $39004, \times 3.1$

3. Lateral view of holotype showing small interbrachial plate above junction of D- and E-ray radials, ROM 39003, × 3.9

4. CD-interray of individual with crushed anal tube, paratype ROM $39005, \times 3.1$

5. Anterior view of above, with B-ray to left. Note three primibrachials in A-ray and two each in B- and E-rays. See Text-fig. 16C for diagram of this specimen. Paratype ROM $39005, \times 3.1$
6. Anterior view of juvenile, paratype ROM $39006, \times 3.3$

7. Holotype viewed from CD-interray. Note long anal tube extending beyond secundaxillaries, with proximal portion sutured to C-ray. Distal coiling of arms is well shown in C-ray. See Text-fig. 16B for diagram of this specimen. ROM 39003, $\times$ 3.1

8. Anterior view of holotype. Note irregular perisomic plates in EA-interray that extend beyond secundaxillaries. See Text-fig. $16 \mathrm{~A}$ for diagram of this specimen. ROM $39003, \times 3.1$

9. Enlargement of perisomic plates in EA-interray of holotype, ROM $39003, \times 9.6$ 

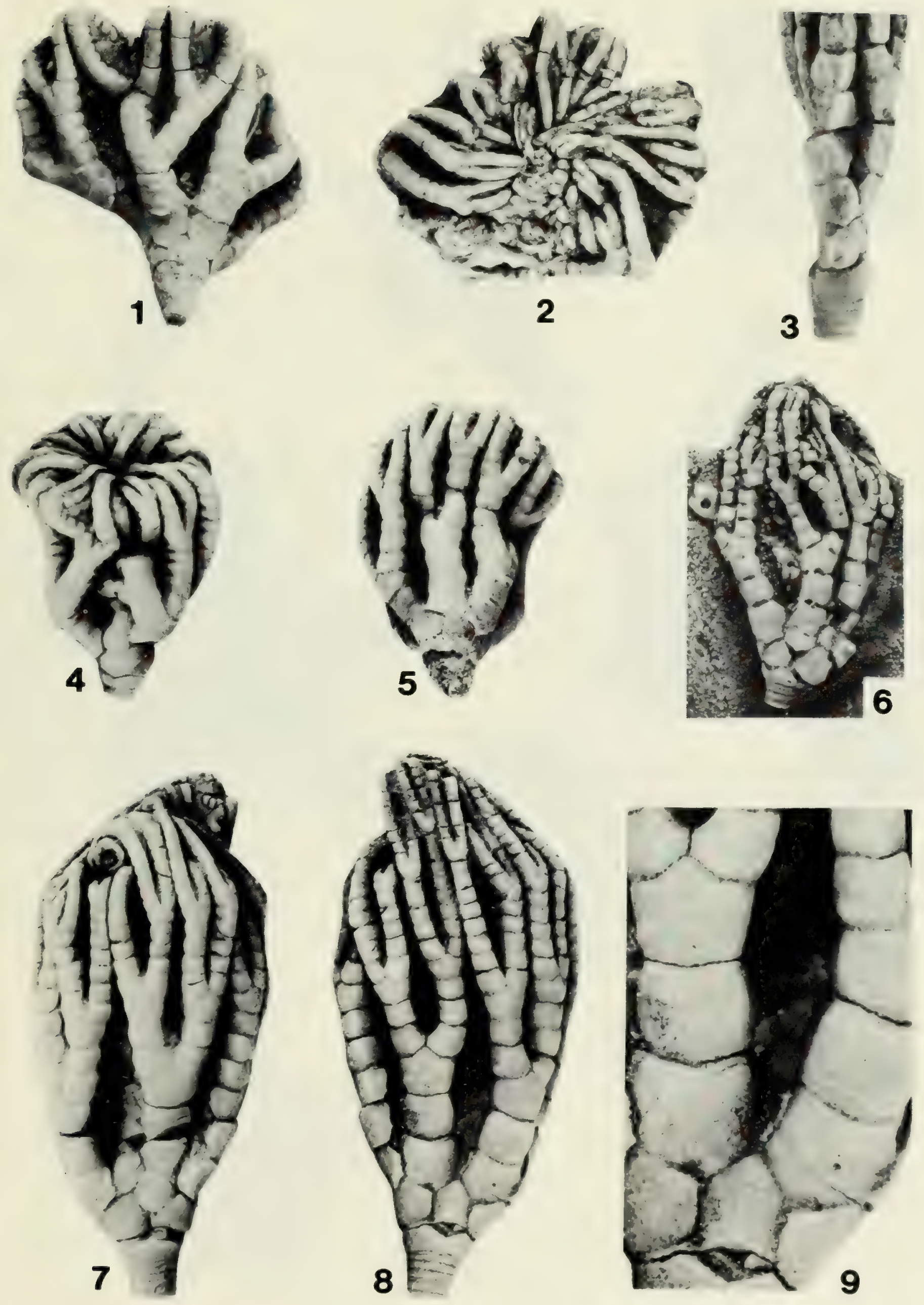
Plate 9, figs. $1-8$

Promopalaeaster? granti (Spencer) 1884, n. comb. Cabot Head Formation at Ball's Falls on Twenty Mile Creek near Jordan, Ontario

1. Aboral view of juvenile. Note general absence of accessory ossicles, ROM $39060, \times 3.2$

2. Aboral view of typical individual. Note uniform tapering of rays. Radials, superomarginals, and marginals are poorly differentiated from accessory ossicles that do not extend to brachia extremities. Madreporite is visible near junction of two rays directed towards right. Centre of disc is not preserved. See Text-fig. 17A for restoration of this specimen. ROM 39059, $\times$ 2.4

3. Madreporite of above enlarged to show its striate appearance. Note tuberculate ornamentation of nearby ossicles. ROM 39059, $\times 9.3$

4. Oral view of well-preserved immature individual. Note prominent mouth-angle plates and single small interbrachial ossicle in each arc bounded laterally by two pairs of adambulacral ossicles. See Text-fig. 17D for diagram of part of this specimen. ROM $39061, \times 3.4$
5. Aboral view of large, possibly gerontic individual. Each ray is composed of tuberculate radial, superomarginal, and marginal columns that are poorly differentiated from intervening rows of accessory ossicles. A maximum of nine rows of ossicles is present in proximal portions of each brachium. Madreporite is visible near junction of two brachia directed towards right. Centre of disc has collapsed. ROM 39062, × 3.1

6. Oral view of exceptionally well-preserved adult. Inferomarginal frame does not extend to extremities of rays. Terminal or ocular ossicle is preserved in brachium directed towards top of plate. Note lath-shaped ambulacral plates, each with a diagonal keel, placed in opposite arrangement; note also pustulose nature of inferomarginals. See Text-fig. 17B, E for diagrams of this individual. ROM 39063, × 3.4

7. Enlargement of brachia of above individual. Note terminal (ocular) ossicle and lath-shaped ambulacrals, each with a diagonal ridge. $\mathrm{ROM} 39063, \times 6.5$

8. Adoral view of large individual. Each interbrachial ossicle is bounded laterally by up to four pairs of adambulacral ossicles. ROM $39064, \times 3.1$ 


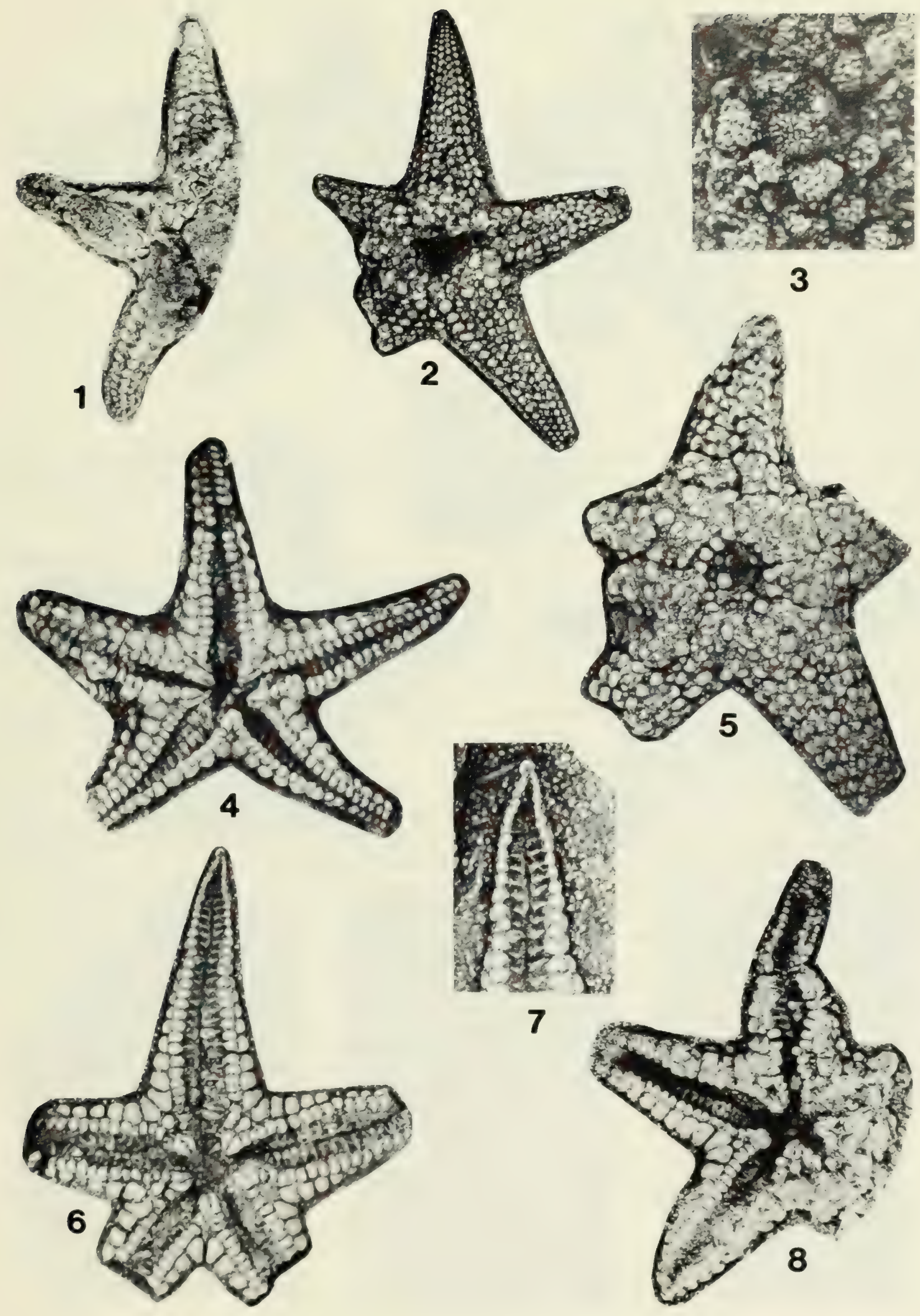


Plate 10 , figs, $1-8$

Figs. 1-4 Medinaster orbiculus gen. et sp. nov. Cabot Head Formation at Ball's Falls on Twenty Mile Creek near Jordan, Ontario

1. Aboral view of holotype. Each ray is composed of radial, superomarginal, and marginal columns; each column is separated by, and strongly differentiated from, intervening rows of smaller, shardlike accessory ossicles that do not extend to extremities of brachia. Ossicle surfaces are smooth, without tuberculate ornamentation of Promopalaeaster? granti (Pl. 9, fig. 3). Note large, trigonal form of proximal superomarginals. Unusually large, elevated madreporite overlaps adjacent ossicles. Brachium directed towards lower left of plate was apparently contracted at time of death, but arm to left above it was fully extended. See Text-fig. 18A for a diagrammatic reconstruction of this asteroid. ROM $39056, \times 3.0$

2. Adoral view of holotype. Note prominent mouth-angle plates; single small, depressed interbrachial ossicle in each arc; and robust structure of inferomarginal frame, which extends to extremities of rays. Inferomarginals are pustulose. Ambulacral ossicles are placed in opposite arrangement. See Text-fig. 18C for diagram of this specimen. ROM 39056, × 3.0

3. Aboral view of juvenile asteroid, probably of this species. Note almost complete absence of accessory plates, apparent absence of madreporite, and irregular boundaries of radial and superomarginal ossicles. See Text-fig. 18B for diagram of this specimen. Paratype ROM $39057, \times 6.3$
4. Enlargement of madreporite of holotype. Prominent grooves, some anastomosing, radiate from depressed centre. ROM 39056 , $\times 6.0$

Fig. 5 Juvenile Promopalaeaster? granti, adoral view. Ambulacral furrows are almost completely closed. See Text-fig. 17C for diagram of part of this individual. Cabot Head Formation at Ball's Falls on Twenty Mile Creek near Jordan, Ontario. ROM 39029b, × 4.8

Figs. 6-8 Macrostylocrinus jordanensis sp. nov. Cabot Head Formation at Ball's Falls on Twenty Mile Creek near Jordan, Ontario.

6. Holotype centred on BC-interray. Interrays are strongly depressed. Robust nature of arms and cuneate form of proximal free brachials are well shown. See Text-fig. 7 for diagram of this specimen. ROM $38997 \mathrm{a}, \times 2.9$

7. Lateral view of complete crown with crushed cup, paratype ROM 38998b, $\times 2.1$.

8. Lateral view of small individual, paratype ROM $38988 \mathrm{a}, \times$ 2.6 


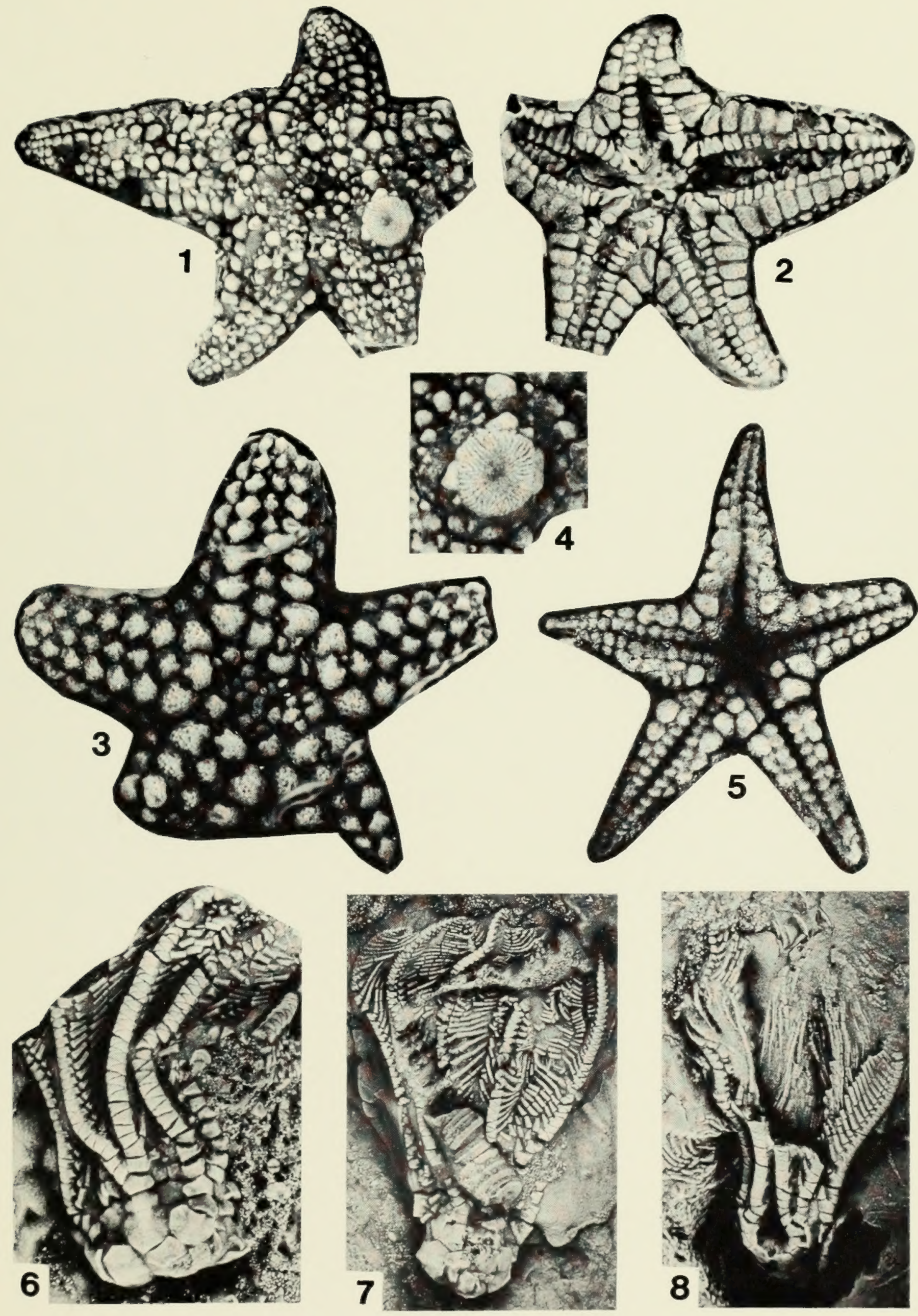






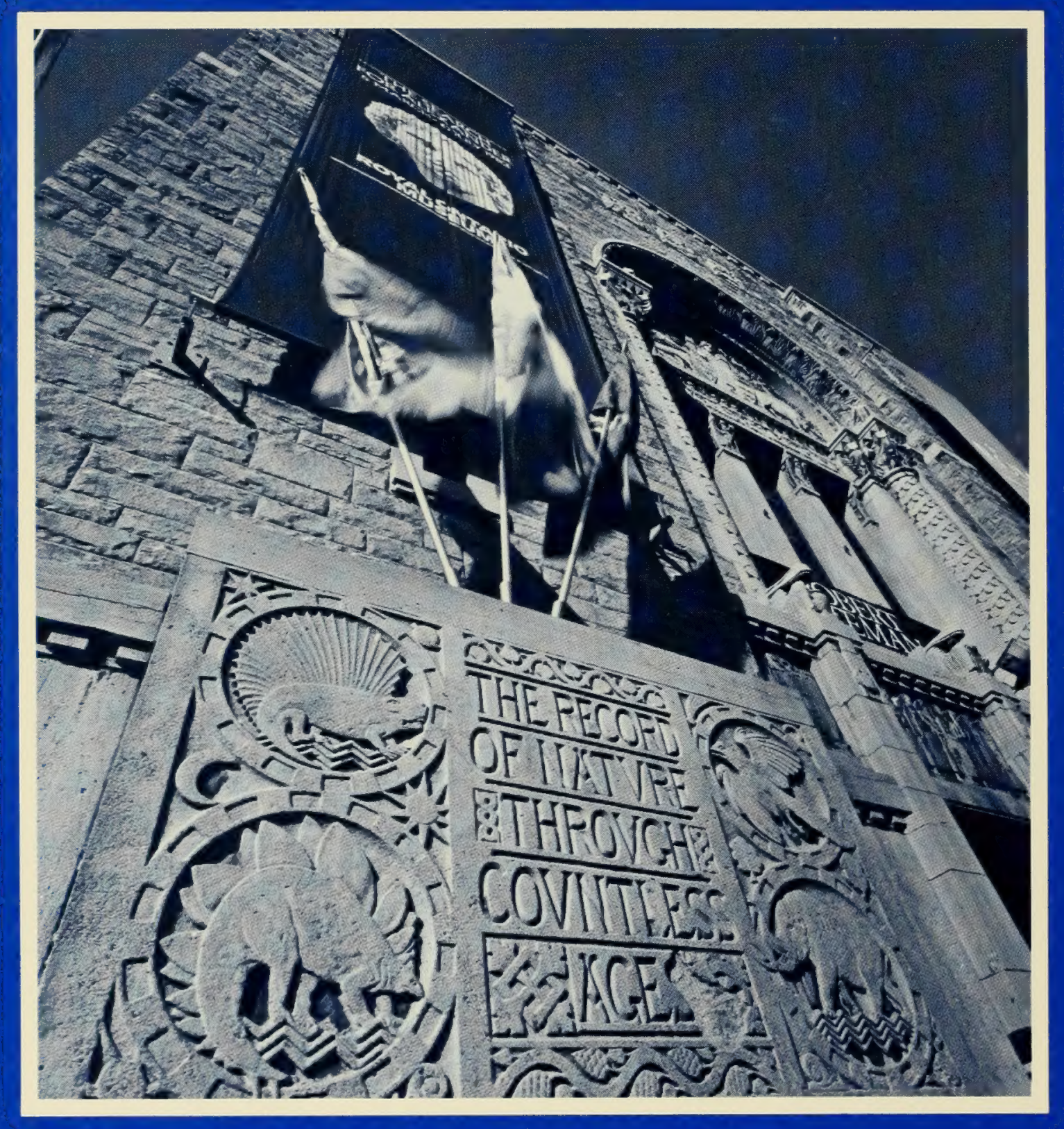

ISBN 0-88854-298-4

ISSN 0384-8159 